\title{
Pensioenverwachtingen en personeelsbeleid : verslag van de ROA enquête 2011
}

Citation for published version (APA):

Fouarge, D., de Grip, A., \& Montizaan, R. M. (2011). Pensioenverwachtingen en personeelsbeleid : verslag van de ROA enquête 2011. Researchcentrum voor Onderwijs en Arbeidsmarkt, Faculteit der Economische Wetenschappen. ROA Reports No. 9 https://doi.org/10.26481/umarep.2011009

Document status and date:

Published: 01/01/2011

DOI:

10.26481/umarep.2011009

Document Version:

Publisher's PDF, also known as Version of record

\section{Please check the document version of this publication:}

- A submitted manuscript is the version of the article upon submission and before peer-review. There can be important differences between the submitted version and the official published version of record.

People interested in the research are advised to contact the author for the final version of the publication, or visit the DOI to the publisher's website.

- The final author version and the galley proof are versions of the publication after peer review.

- The final published version features the final layout of the paper including the volume, issue and page numbers.

Link to publication

\footnotetext{
General rights rights.

- You may freely distribute the URL identifying the publication in the public portal. please follow below link for the End User Agreement:

www.umlib.nl/taverne-license

Take down policy

If you believe that this document breaches copyright please contact us at:

repository@maastrichtuniversity.nl

providing details and we will investigate your claim.
}

Copyright and moral rights for the publications made accessible in the public portal are retained by the authors and/or other copyright owners and it is a condition of accessing publications that users recognise and abide by the legal requirements associated with these

- Users may download and print one copy of any publication from the public portal for the purpose of private study or research.

- You may not further distribute the material or use it for any profit-making activity or commercial gain

If the publication is distributed under the terms of Article $25 \mathrm{fa}$ of the Dutch Copyright Act, indicated by the "Taverne" license above, 


\title{
Pensioenverwachtingen en personeelsbeleid
}

Verslag van de ROA enquête 2011

\author{
Didier Fouarge \\ Andries de Grip \\ Raymond Montizaan
}

ROA-R-2011/9 


\section{Colofon}

(C) Researchcentrum voor Onderwijs en Arbeidsmarkt (ROA). Niets uit deze uitgave mag op enige manier worden verveelvoudigd zonder voorafgaande schriftelijke toestemming van de directeur van het ROA.

\section{Researchcentrum voor Onderwijs en Arbeidsmarkt}

School of Business and Economics

Maastricht University

\section{Vormgeving}

ROA secretariaat, Maastricht

\section{Verkoop}

Researchcentrum voor Onderwijs en Arbeidsmarkt email: secretary-roa-sbe@maastrichtuniversity.nl website: www.roa.nl

ISBN: 978-90-532I-5I2-8

maart $20 \mathrm{I} 2$ 


\section{Inhoud}

Voorwoord $\quad$ v

Samenvatting vii

I Inleiding I

2 Pensioenverwachtingen en spaargedrag $\quad 7$

2.I Verwachtingen over pensioenuitkering $\quad 7$

$\begin{array}{ll}2.2 \text { Verwachte pensioenleeftijd } & \text { I3 }\end{array}$

$\begin{array}{ll}2.3 \text { Deeltijdpensionering } & \text { I7 }\end{array}$

2.4 Eigen pensioenvoorzieningen 19

2.5 Financiële kennis en pensioenverwachtingen 20

2.6 Effectiviteit bonus om langer door te werken 22

3 Anticiperen op langer doorwerken $\quad 25$

3.I Impact afschaffing FPU op de verwachte pensioenuitkering 26

3.2 Impact afschaffing FPU op de verwachte pensioenleeftijd 28

3.3 Werkgever biedt alternatieve mogelijkheden voor vervroegde uittrede 29

3.4 Verhoging AOW leeftijd en pensioenverwachtingen 30

4 Werknemersinzet en percepties van het gevoerde personeelsbeleid 35

4.I Werknemersinzet 35

4.2 Personeelsbeleid: aandacht voor functioneren en loopbaanontwikkeling 40

4.3 Trainingsparticipatie 49

5 Loon en productiviteit 53

5.I Loonkosten en productiviteit $\quad 53$

5.2 Productieve vaardigheden $\quad 57$

5.3 Het belang van langer doorwerken voor de organisaties $\quad 58$

5.4 Rol van leeftijd bij voorkeur voor sollicitanten

6 Beoordeling van personeelsbeleid door werkgevers 65

6.I HR instrumenten 65

6.2 HRM beleid gericht op oudere werknemers $\quad 69$

$\begin{array}{ll}6.3 \text { Scholing } & 72\end{array}$ 
7 Relatie tussen HR instrumenten en werknemersuitkomsten

7.I Vergelijking percepties van werkgevers en werknemers over personeelsbeleid

7.2 Relatie tussen oordeel personeelsbeleid van de werkgever en pensioenverwachtingen

7.3 Relatie tussen oordeel van de werkgever over personeelsbeleid en de werkinzet van medewerkers

7.4 Relatie tussen de ingezette HR instrumenten volgens de werkgever en pensioenverwachtingen

7.5 Relatie tussen de ingezette HR instrumenten en de werkinzet

7.6 Relatie tussen het volgens de werkgever gevoerde ouderenbeleid op de pensioenverwachtingen

7.7 Relatie tussen het volgens de werkgever gevoerde ouderenbeleid en de werkinzet

8 Conclusie

8.I Samenvatting

8.2 Aanbevelingen

Bijlage

IOI 


\section{Voorwoord}

Dit onderzoek wordt gesubsidieerd door het Ministerie van Sociale Zaken en Werkgelegenheid en Stichting Instituut GAK. De dataverzameling is mede bekostigd door het Pensioenfonds ABP (ABP), het Bedrijfstakpensioenfonds voor de Bouwnijverheid (bpfBOUW), het Bedrijfstakpensioenfonds Schoonmaak- en Glazenwassersbedrijf (SGB) en het Pensioenfonds voor de Woningcorporaties (SPW). Daarnaast is gebruik gemaakt van de administratieve databestanden van de Aannemersfederatie Bouw \& Infra Nederland (AFNL), Vereniging van Woningcorporaties (AEDES), en de Nederlandse Bond van Timmerfabrikanten (NBvT). 



\section{Samenvatting}

De arbeidsparticipatie onder 55-plussers is de afgelopen twintig jaar flink toegenomen. Dit is voor een belangrijk deel toe te schrijven aan de veranderingen in de pensioenrechten waardoor men langer moet doorwerken om hetzelfde pensioen te kunnen krijgen. Het huidige beleid is er nog steeds sterk op gericht om de arbeidsparticipatie van ouderen verder te stimuleren. Vanuit dit perspectief zijn de thema's duurzame inzetbaarheid, langer doorwerken en Active Aging duidelijk op de agenda komen te staan.

In dit rapport wordt verslag gedaan van een onderzoek naar de bereidheid om langer door te werken en in hoeverre het gevoerde personeelsbeleid hier op aansluit. Het onderzoek richt zich op de verschillende sectoren die zijn aangesloten bij het Pensioenfonds ABP (ABP), het Bedrijfstakpensioenfonds voor de Bouwnijverheid (bpfBOUW), het Bedrijfstakpensioenfonds Schoonmaak- en Glazenwassersbedrijf (SGB), en het Pensioenfonds voor de Woningcorporaties (SPW).

De belangrijkste uitkomsten laten zich als volgt samenvatten:

I. Veel werknemers overschatten de hoogte van het pensioen dat zij zullen krijgen. Vooral bij jongere werknemers (in dit onderzoek zijn dit de 35-45 jarigen) is het pensioenbewustzijn nog onvoldoende ontwikkeld. Meer in het algemeen is gebrekkige financiële kennis een belangrijke oorzaak van te optimistische verwachtingen ten aanzien van de pensioenleeftijd. Deze te rooskleurige verwachtingen leiden er toe dat mensen minder investeren in hun pensioen, waardoor zij later relatief weinig pensioenrechten hebben (hoofdstuk 2).

2. De opeenvolgende hervormingen van het pensioenstelsel zorgen er voor dat werknemers steeds meer flexibiliteit krijgen in hun pensioneringsbeslissing, maar dat een vroegtijdige volledige arbeidsmarktuittrede steeds duurder wordt. Deeltijdpensioen kan daarom een aantrekkelijke optie zijn om alsnog gedeeltelijk een vervroegde arbeidsmarktuittrede te kunnen realiseren. Het blijkt dat jongere werknemers inderdaad vaker denken dat ze later van deeltijdpensionering gebruik gaan maken. Dit geldt voor zowel de sectoren overheid en onderwijs als voor de bouw en de woningcorporaties (hoofdstuk 2).

3. Een doorwerkbonus is in beperkte mate effectief om lager werken te stimuleren (hoofdstuk 2). 22,5\% van de werknemers zou langer werken als zij een bonus krijgen van $€ 2.400$. Echter, een hogere doorwerkbonus motiveert weliswaar 
meer mensen om langer door te werken, maar deze groep wil minder lang doorwerken dan degenen die ook tegen een lagere bonus bereid waren om hun arbeidsmarktuittrede uit te stellen. Een bonus van $€ 2.400$ leidt er toe dat werknemers 16,7 maanden langer willen werken, terwijl bij een bonus van $€$ 4.700 werknemers gemiddeld genomen verwachten dat ze maar I4,5 maanden langer werken. Dit roept de vraag op in hoeverre de kosten van een hogere doorwerkbonus de baten zullen overtreffen.

4. De afschaffing van de FPU binnen de ABP-regeling heeft een sterk effect gehad op de verwachtingen die werknemers met versoberde pensioenrechten van hun pensioen hebben. Het verschil in de verwachte pensioenuitkering tussen werknemers met versoberde en werknemers met de oude meer genereuze pensioenrechten is vrij stabiel en komt goed overeen met het feitelijke verschil in pensioenrechten (hoofdstuk 3).

5. Daarentegen is het effect van de financiële prikkel om langer te gaan werken, dat de afschaffing van het FPU wilde bewerkstelligen, de afgelopen jaren veel geringer geworden: In $201 \mathrm{I}$ was het verschil in de verwachte pensioenleeftijd tussen werknemers met versoberde rechten en werknemers met de oude meer genereuze pensioenrechten veel kleiner dan kort na de herziening van het pensioenstelsel in 2006. Wat dat betreft is het opmerkelijk dat het effect van de financiële crisis (en de daaraan gerelateerde dekkingsgraadproblemen van de pensioenfondsen) op de verwachte pensioenuitkeringen en de verwachte pensioneringsleeftijd groter lijkt te zijn dan die van de afschaffing van de FPU regeling (hoofdstuk 3). Werknemers in de sectoren wetenschappelijk onderwijs, onderzoek en wetenschapsbeleid en het hoge beroepsonderwijs denken later met pensioen te gaan dan de werknemers in de andere sectoren. Opvallend is dat jongere werknemers in het primair onderwijs eerder met pensioen denken te gaan dan jongere werknemers in andere sectoren.

6. In het onlangs afgesloten pensioenakkoord is vastgelegd dat degenen die geboren zijn in de jaren 1955 tot en met 1959 pas op 66 jarige leeftijd recht hebben op AOW. Het blijkt dat werknemers die geboren zijn in deze jaren vier maanden later met pensioen verwachten te gaan dan degenen die geboren zijn in de jaren daarvoor. Van degenen die geboren zijn in de jaren 1955-1959 denkt $17 \%$ op 66-jarige leeftijd met pensioen te gaan, tegenover I\% van de werknemers die geboren zijn in de jaren daarvoor (hoofdstuk 3).

7. Oudere werknemers blijken niet minder bevlogen te zijn voor hun werk dan jongere werknemers. Ook maken ze niet minder onbetaalde overuren. Opmerkelijk is ook dat het aantal ziekmeldingen bij oudere werknemers een stuk lager ligt (13,3\%-punt lager) dan bij jongere medewerkers. De oudere werknemers die zich ziek melden zijn echter wel veel langer ziek. Dit betekent dat het overgrote deel van ouderen geen gezondheidsproblemen ondervindt die leiden tot ziekteverzuim. Dit suggereert dat de gezondheid voor de meeste werknemers geen belemmering zal vormen om langer door te kunnen werken (hoofdstuk 4). 
8. Werkgevers vinden dat de loonkosten van oudere werknemers te hoog zijn ten opzichte van hun arbeidsproductiviteit. Het verschil in waardering tussen productiviteit en loon van 55-64 jarigen is vooral groot bij de politie en het beroeps- en volwassenenonderwijs. Het verschil is het kleinst bij de $\mathrm{ABP}$-sectoren het hoger beroepsonderwijs, de vrijwillige toetreders en de sector 'overige'. In de schoonmaak- en glazenwassersbedrijven gaat de lage waardering voor de productiviteit van de oudere werknemers gepaard met een lage waardering van de loonkosten waardoor beide in evenwicht zijn (hoofdstuk 5).

9. Desalniettemin scoren oudere werknemers in de ogen van hun werkgevers op een aantal belangrijke productieve vaardigheden juist beter dan jongeren. Daarbij gaat het om hun kennisniveau, deskundigheid, zelfstandigheid, nauwkeurigheid, planning van het werk, leidinggeven en het omgaan met verantwoordelijkheid (hoofdstuk 5).

Io. Dat oudere werknemers relatief duurder zijn, zien werkgevers als een belemmering om hen langer in dienst te houden. Dit speelt vooral voor werkgevers in het voortgezet onderwijs, de beroeps- en volwasseneneducatie en bij de water, energie en nutsbedrijven. Daarnaast speelt ook het feit dat, in de ogen van de werkgevers, oudere werknemers zelf niet langer willen werken (hoofdstuk 5). Dat werknemers volgens de werkgever zelf niet langer door willen werken wordt vaak aangegeven in de water, energie en nutsbedrijven, het beroeps- en volwassenenonderwijs en de gemeenten.

II. Slechts I8\% van de werkgevers vindt het belangrijk dat oudere werknemers langer doorwerken. Dit wijst er op dat de kosten-baten afwegingen van werkgevers op microniveau in de praktijk zwaarder wegen dan het macrobelang om oudere werknemers te stimuleren om door te werken.

I2. De bereidheid van werkgevers om ouderen aan te nemen wanneer zij de keuze hebben tussen een jongere of een oudere sollicitant is zeer gering (hoofdstuk 5). De sectorverschillen zijn op dit punt klein: alleen in het hoger beroepsonderwijs speelt de leeftijd een minder belangrijke rol dan in andere sectoren. Oudere werknemers slagen er niet in om een nieuwe functie te krijgen, ook al hebben ze veel meer werkervaring (hoofdstuk 6).

I3. In veel organisaties wordt gebruik gemaakt van Persoonlijke opleidings- en ontwikkelingsplannen (POP's). Ongeveer 54\% van de organisaties hanteert dergelijke plannen, maar dit percentage is beduidend lager bij het rijk, de bouw, het wetenschappelijk onderwijs, onderzoek en wetenschapsbeleid en de schoonmaak- en glazenwassersbedrijven (hoofdstuk 6).

I4. Het voeren van een leeftijdsbewust of levensfasebewust personeelsbeleid kan van belang zijn om werknemers duurzaam inzetbaar te houden. Echter, slechts iets meer dan een derde van de organisaties voert een dergelijk beleid. Bovendien zijn er slechts weinig werkgevers die een activerend personeelsbeleid voeren dat er op gericht is om oudere werknemers langer te kunnen laten werken (hoofdstuk 6). 
15. Mede daardoor zijn werknemers vrij negatief over het in hun organisatie gevoerde personeelsbeleid. Werknemers zijn het minst positief over het gevoerde personeelsbeleid bij de politie en de beroeps- en volwasseneneducatie. Ze zijn het meest positief bij de woningcorporaties, water, energie en nutsbedrijven en de provincies en waterschappen. Slechts weinig werknemers geven echter aan dat hun werkgever bereid is om hun taakbelasting aan te passen als dat nodig zou zijn. Vooral oudere werknemers geven aan dat hun werkgever niet meer aandacht is gaan besteden om hen langer in dienst te houden (hoofdstuk 4).

I6. Werkgevers lijken wel een activerend trainingsbeleid te voeren. Positieve uitschieters zijn het primair onderwijs, de woningcorporaties en de provincies en waterschappen. Er wordt daarentegen relatief weinig training gevolgd door de medewerkers in de sector wetenschappelijk onderwijs, onderzoek en wetenschapsbeleid, in de bouw (mogelijk omdat in die sectoren meer op informele wijze wordt geleerd), maar vooral ook in de schoonmaak- en glazenwassersbedrijven (hoofdstuk 6). De trainingsparticipatie van oudere werknemers is weliswaar lager dan bij jongere medewerkers, maar blijft substantieel. Het gebrek aan motivatie van oudere werknemers om een cursus of training te volgen blijkt een belangrijke oorzaak te zijn voor hun lagere trainingsdeelname. Jongere werknemers nemen zelf vaker het initiatief om een cursus te volgen, terwijl bij ouderen het initiatief vaker van de werkgever komt (hoofdstuk 4).

I7. Werkgevers en werknemers verschillen sterk in hun oordeel over het gevoerde personeelsbeleid. Werkgevers zijn hierover doorgaans een stuk positiever en onderschatten daarmee de ontevredenheid van hun eigen werknemers over het gevoerde personeelsbeleid (hoofdstuk 7).

18. Vooral in de universitair medische centra, de sector wetenschappelijk onderwijs, onderzoek en wetenschapsbeleid en bij de politie zijn er tussen werkgevers en werknemers grote verschillen in het oordeel over het door de organisatie gevoerde personeelsbeleid. Werkgevers onderschatten in deze sectoren vooral de ontevredenheid van hun werknemers over: - de betrokkenheid van de organisatie bij het welzijn van de werknemers, - de zorg voor hulp en ondersteuning wanneer dat nodig is, - de bereidheid van de organisatie om zich in te zetten voor werknemers, - de inzet om werknemers langer aan het werk te houden. (hoofdstuk 7).

19. Het blijkt dat werknemers die een positiever oordeel hebben over het door hun organisatie gevoerde personeelsbeleid voor wat betreft de mogelijkheden om in deeltijd te werken, de betrokkenheid bij het welzijn van hun werknemers en de bereidbaarheid om de geestelijke taakbelasting aan te passen wanneer dat nodig is, later met pensioen denken te gaan (hoofdstuk 4).

20. Werknemers die een positiever oordeel hebben over het door hun organisatie gevoerde personeelsbeleid zijn meer tevreden over hun baan en tonen ook 
meer bevlogenheid in hun werk. Bovendien hebben ze een lager ziekteverzuim (hoofdstuk 7).

2I. Doordat werkgevers een heel ander oordeel hebben over het gevoerde personeelsbeleid dan hun werknemers is er nauwelijks een relatie tussen het volgens de werkgever gevoerde personeelsbeleid en de pensioenverwachtingen en de inzet van hun werknemers. Voor het vergroten van de inzet van hun werknemers, verdient het aanbeveling als organisaties: - hun leidinggevenden aansporen meer waardering te laten blijken voor het functioneren van hun medewerkers,

- medewerkers een goed loopbaanperspectief bieden,

- laten zien dat ze bereid zijn om zich in te zetten voor hun werknemers. (hoofdstuk 8). 



\section{Inleiding}

De situatie rond de arbeidsmarktuittrede van oudere werknemers is sinds een aantal jaren drastisch aan het veranderen. De financiële crisis en de lage rente heeft een grote impact gehad op de dekkingsgraden van de pensioenfondsen waardoor de indexering van de pensioenen onzeker is geworden. Deze onzekerheid wordt nog versterkt door de vergrijzing en de ontgroening van de Nederlandse samenleving, waardoor de toekomstbestendigheid van het Nederlands pensioenstelsel in het geding zou kunnen komen.

Zowel de sociale partners als pensioenfondsen hebben als doel om een goed en betaalbaar pensioen te realiseren dat voor de huidige, maar ook voor de komende generaties betaalbaar blijft. Daarom zijn er in de afgelopen jaren al diverse veranderingen doorgevoerd in de sfeer van de werknemersverzekeringen, VUT en prepensioen en de loon- en inkomstenbelasting om het langer doorwerken te stimuleren. Het pensioenakkoord omvat de meest recente plannen waarmee de ingangsleeftijd van de AOW in 2020 wordt verhoogd van 65 naar 66 jaar en daarna wordt gerelateerd aan de levensverwachting van de gepensioneerden.

Werknemers zullen zich daarom moeten instellen op een verlenging van hun loopbaan en moeten zich afvragen hoe ze dat op een plezierige, gezonde en productieve wijze kunnen doen bij hun huidige werkgever, of elders. Maar het langer doorwerken van oudere werknemers heeft vanzelfsprekend ook grote gevolgen voor werkgevers. Zij zullen zich moeten instellen op een situatie waarin er meer 55-plussers aan het werk zijn, maar ook op een grotere variatie in de uittredingsleeftijden als gevolg van de introductie van meer flexibele pensioenregelingen, zoals bijvoorbeeld het ABP Keuzepensioen. Bovendien zullen werkgevers zich moeten beraden op welke wijze zij hierop reageren. Daarbij gaat het om de vraag op welke manier zij uiteenlopende groepen werknemers gemotiveerd, gezond en productief aan het werk kunnen houden dan wel naar ander werk kunnen toe leiden? Deze rol van de werkgever is tot op heden in het onderzoek met betrekking tot de arbeidsmarkt van ouderen sterk onderbelicht gebleven.

In dit rapport zal verslag worden gedaan van de belangrijkste uitkomsten van het onderzoek dat wij gedaan hebben in de verschillende sectoren die zijn aangesloten bij het Pensioenfonds ABP (ABP), het Bedrijfstakpensioenfonds voor de Bouwnijverheid (bpfBOUW), het Bedrijfstakpensioenfonds Schoonmaak en Glazenwassersbedrijf 
(SGB), en het Pensioenfonds voor de Woningcorporaties (SPW). Daarbij onderscheiden we I4 specifieke overheids- en onderwijs sectoren, alsmede de bouwsector, de woningcorporaties en de schoonmaak- en glazenwassersbedrijven. Deze fondsen bedienen een aantal van de meest vergrijsde sectoren van de Nederlandse economie. Dit geldt met name voor de sectoren beroeps en volwasseneneducatie, hoger beroepsonderwijs, primair en voortgezet onderwijs, provincies en water, energie en nutsbedrijven.

Door de leeftijdsstructuur van het klantenbestand in deze sectoren zal de arbeidsmarktuitstroom vanwege pensionering in de komende jaren sterk toenemen. Hierdoor zal met name het onderwijs over enkele jaren met grote knelpunten in de personeelsvoorziening worden geconfronteerd. Maar ook de andere sectoren zullen te maken krijgen met een veel krappere arbeidsmarkt. Vooral voor de werknemers in de leeftijd van 45-60 jaar zijn de veranderingen (afschaffing VUT, prepensioen e.d.) groot en aangenomen mag worden dat voor deze groep de spilleeftijd van vrijwillige (pensioen-) uittreding zo'n 2 tot 4 jaar zal opschuiven ten opzichte van de huidige generatie 6o-plussers. Bovendien kan worden verwacht dat de variatie in de uittredingsleeftijden sterk zal toenemen als gevolg van de toegenomen flexibiliteit die is geïntroduceerd in de pensioenregelingen. Dit roept de vraag op wat de incentives zijn in de sfeer van de pensioenvoorziening en het personeelsbeleid die maken dat werknemers productief inzetbaar blijven en voldoende gemotiveerd willen (blijven) werken. Ook roept het de vraag op wat de CAO's in verschillende sectoren op deze punten te bieden hebben en in hoeverre de arbeidsorganisaties adequaat kunnen inspelen op de toenemende flexibiliteit in het uittredegedrag. Met andere woorden, worden werknemers in staat gesteld om zo optimaal mogelijk gebruik te maken van de pensioenregelingen die de eerder genoemde pensioenfondsen? Centraal staat daarbij de pensioenvoorziening die door de toegenomen flexibiliteit en keuzeruimte er voor zorgt dat de relevantie van maatwerk en een effectief active aging beleid sterk is toegenomen.

Uit recent onderzoek van TNO blijkt dat veel werknemers en bedrijven zich nog maar weinig rekenschap geven van de noodzaak om langer door te werken. ${ }^{\mathrm{I}}$ Het percentage werknemers dat aangeeft tot 65 jaar te kunnen en willen werken is weliswaar de afgelopen jaren gestegen, maar bedraagt nog steeds minder dan de helft. Maar nog opmerkelijker is dat minder dan $25 \%$ van de bedrijven het belangrijk vindt dat hun werknemers tot hun 65ste blijven werken. ${ }^{2}$ De werkenden in de sector overheid en het onderwijs scoren op dit punt overigens bovengemiddeld. Uit een eerder ROA/ABP onderzoek van Van Loo c.s. (2006) blijkt dat van de werknemers die jonger zijn dan 45 jaar $64 \%$ verwacht dat ze tot hun 65 e of nog langer door zullen werken. Daar staat echter tegenover dat veel oudere werknemers in de overheids- en onderwijssector vrij negatief zijn over de aandacht die hun werkgever heeft voor het op peil houden van

I. Zie TNO (2009), Arbobalans 2009: Kwaliteit van de arbeid, effecten en maatregelen in Nederland, Hoofddorp.

2. J. van Loo., A. de Grip en R. Montizaan (2005), Active aging bij Overheid-en Onderwijs, ROA/ABP, Maastricht/Heerlen. 
hun inzetbaarheid in het arbeidsproces. ${ }^{3}$ Dit wijst nogmaals op de grote urgentie om te komen tot een adequaat HRM beleid dat gericht is op een duurzame inzetbaarheid van de beroepsbevolking.

Ook voor de bouwsector, waar de fysieke werkbelasting hoog is, is een goede invulling van het personeelsbeleid cruciaal om het mogelijk te maken dat mensen productief en met plezier langer blijven doorwerken. De bouwsector heeft te maken met een hoge uitstroom op relatief jonge leeftijd. Bovendien laten prognoses zien dat deze sector in de toekomst te maken krijgt met grote knelpunten in haar personeelsvoorziening (ROA, 2009). ${ }^{4}$ Daardoor zullen ook in deze sector initiatieven moeten worden ontwikkeld om oudere werknemers duurzaam inzetbaar te houden. Deze initiatieven zullen bovendien moeten aansluiten bij de toegenomen flexibiliteit van het pensioenstelsel. Daarbij speelt onder andere ook de vraag in hoeverre voor oudere medewerkers een verandering van functie of het takenpakket binnen een functie kan worden gefaciliteerd.

Ons onderzoek zal zich daarom richten op het beantwoorden van de volgende vijf onderzoeksvragen:

I. Hoe succesvol zijn de incentives in het pensioenstelsel om oudere werknemers langer productief en met plezier aan het werk te houden?

2. Welke factoren zijn van invloed op het uittredeproces van werknemers?

3. Welke HR instrumenten hanteren werkgevers om oudere werknemers langer met plezier aan het werk te houden en in welke mate zijn de ingezette HR instrumenten succesvol?

4. In hoeverre is er een andere opstelling van de werkgever ten aanzien van pensionering en inzet van oudere medewerkers gewenst?

5. Hoe verhoudt zich de macro wenselijkheid van langer doorwerken tot de micro wensen van de onderneming en de werknemer?

Om deze vragen te beantwoorden zullen wij gebruik maken van twee datasets. De eerste dataset heeft betrekking op de eerste enquête onder een nieuw werkgeverswerknemerspanel voor de overheid- en het onderwijs, de bouwsector, de woningcorporaties en de schoonmaak- en glazenwassersbedrijven, die in $201 \mathrm{I}$ is opgestart. De dataset bestaat uit een combinatie van surveydata met administratieve data van de faciliterende pensioenfondsen en is gebaseerd op een enquête die gehouden is onder een representatieve steekproef van werknemers in de leeftijd van 35 tot 65 jaar, en een werkgeversenquête die is verstuurd naar werkgevers.

3. R. Montizaan en A. de Grip, (2008), Pensioenverwachtingen en menselijk kapitaal: Active aging bij overheid en onderwijs, ROA/ABP en R. Montizaan en A. de Grip, (2008). Pensioenverwachtingen en menselijk kapitaal, Economisch Statistische Berichten, ESB-dossier Werk in uitvoering, Vol. 93, april 2008, pp. 30-35.

4. ROA (2009), De arbeidsmarkt naar opleiding en beroep tot 20I4, Maastricht. 
Het werknemerspanel bevat informatie over de werkmotivatie, het takenpakket, de verwachte pensioenrechten en het verwachte inkomen na pensionering en de voorzieningen die de werknemers in deze sectoren zelf hebben getroffen. Daarnaast geeft het panel informatie over het beeld dat werknemers hebben van de HR instrumenten in de organisatie waar ze werkzaam zijn. De werkgeversenquête geeft een gedetailleerd beeld van de HR instrumenten die de werkgevers inzetten om oudere werknemers langer met plezier inzetbaar te houden. Daarbij kan men denken aan HR instrumenten op het terrein van selectie, training, arbeidsvoorwaarden, interne promotie, incidentele beloning, coaching, werkzekerheid, participatie, leerklimaat en functionerings- en beoordelingsgesprekken, maar ook aan het gevoerde beleid ten aanzien van de arbeidsomstandigheden, verzuimbegeleiding en de mogelijkheid tot werkaanpassingen. Bovendien wordt in de werkgeversenquête expliciet aandacht besteed aan het karakter van het gevoerde beleid, i.e., wordt er op de genoemde terreinen een ad hoc of structureel HRM beleid gevoerd en is het beleid gericht op prestaties van de individuele werknemers of van de organisatie.

Zoals gezegd, is de werknemersenquête verstuurd naar een representatieve steekproef van werknemers van de overheid, onderwijs, de bouwsector en de woningcorporaties en de schoonmaak- en glazenwassersbedrijven.5 De benadering van de werknemers vond in twee stappen plaats. In de eerste stap werd er door het pensioenfonds naar 50.400 werknemers een brief gestuurd met het verzoek om deel te nemen aan het onderzoek en hun e-mailadres op te sturen. In de tweede stap werden de mensen die hun e-mailadres hadden toegestuurd door het ROA benaderd per e-mail met daarin een link naar de internetenquête. In totaal hebben 5.900 werknemers de enquête ingevuld. Daarbij was de respons bij de overheid en het onderwijs I3,6\%, tegenover I0,I\% bij de woningcorporaties en $5, \mathrm{I} \%$ in de bouwsector.

De werkgeversenquête is verstuurt per e-mail met daarin een link naar de internetenquête naar circa 4.700 werkgevers. Circa I.400 hebben de enquête ingevuld (respons is $28,6 \%$ )

De tweede dataset die in dit rapport wordt gebruikt, maakt het mogelijk om meer specifiek te kijken naar de effecten van het afschaffen van de FPU regeling en invoering van het ABP Keuzepensioen in 2006 die beoogde de arbeidsmarktparticipatie van oudere werknemers in de O\&O-sectoren te verhogen. Door deze wijziging in de pensioenrechten hebben werknemers die geboren zijn in 1950 (of later) geen recht meer op de oude meer genereuze prepensioenrechten (FPU), waardoor zij langer moeten doorwerken om hetzelfde pensioen te krijgen als ze voorheen verwachtten, terwijl degenen die geboren zijn voor I januari 1950 nog gebruik kunnen maken van de oude FPU-regeling. Dit databestand bestaat uit een combinatie van survey data met administratieve data van het $\mathrm{ABP}$ en is gebaseerd op vijf enquêtes die zijn gehouden in de jaren 2007-20II onder een representatief panel van mannelijke full-

5. Vanwege een tegenvallende respons op de werknemersenquête in de schoonmaak- en glazenwassersbedrijven zijn er voor deze sector alleen werkgeversgegevens beschikbaar. 
time werknemers die zijn geboren in 1949 of 1950 . Daarbij is de steekproef verder beperkt tot mannen die reeds sinds 1997 in de publieke sector werkzaam waren en niet vallen onder afwijkende regelingen. ${ }^{6}$

In 2007 bedroeg de bruikbare surveyrespons van dit panel circa 7.000 mannen, waarvan 3.700 mannen die geboren zijn in 1950 en 3.300 mannen die geboren zijn in 1949.7 In 2008, 2009, 2010 en 2011 bestond de bruikbare respons uit respectievelijk 5.600, 6.600 en 6.700 en 5.600 mannen. Het unieke van deze dataset is dat de gegevens betrekking hebben op een homogene groep werknemers van vrijwel dezelfde leeftijd met verschillende pensioenrechten.

Vanwege het experimentele karakter van deze laatste dataset is het mogelijk om de causale relatie te analyseren tussen aan de ene kant de (exogene) veranderingen in de pensioenrechten en aan de andere kant de productiviteit van degenen die hierdoor langer doorwerken en het verwachte uittredegedrag. ${ }^{8}$ Zonder het experimentele karakter en de panelstructuur zou het moeilijk zijn om causale verbanden vast te kunnen stellen, omdat het dan onduidelijk is of de anticipatie van werknemers op een bepaalde pensioenleeftijd hun productiviteit en werkinzet beïnvloedt, of dat een hoge productiviteit en werkinzet juist leidt tot uitstel van pensionering. In dit onderzoek ligt het causale verband echter vast: Degenen die geboren zijn in I950 zullen langer moeten doorwerken om dezelfde pensioenrechten op te bouwen als die van de mensen die geboren zijn in 1949. Voor de eerstgenoemde groep geldt bovendien dat vervroegde pensionering tot een lager pensioen leidt naarmate iemand eerder wil stoppen met werken.

Een bijkomend voordeel van onze onderzoeksopzet is dat de data voor dezelfde personen beschikbaar zijn in vijf opeenvolgende jaren. Het monitoren van de individuele medewerkers over een aantal jaren kan de pensioenplannen van de respondenten goed in kaart brengen. Ook maakt het onderzoek het mogelijk om de ontwikkeling van het active aging beleid te analyseren. Hierdoor kunnen we zien in hoeverre werknemers die geen recht meer hebben op de FPU regeling in de loop van de tijd hun pensioenverwachtingen hebben bijgesteld of actie hebben ondernomen om hun pensioen aan te vullen naarmate zij dichter bij hun pensioen komen.

6. Het merendeel van de mannelijke employees die geboren zijn in 1949 of I950 zijn kostwinner terwijl vrouwen die geboren zijn in deze twee jaren vaak een onderbroken loopbaan hebben. In deze leeftijdsgroep hebben mannen gemiddeld genomen 28 jaar pensioen opgebouwd terwijl vrouwen maar I6 jaar hebben opgebouwd. Bovendien, is alleen een kleine selectieve groep van deze vrouwen nog steeds werkzaam (30\% van alle werknemers geboren in 1949 en 1950), waarvan $72 \%$ ook nog eens werkt in een parttime baan (CBS, Statline 2005). Daarbij geldt eveneens dat deze groep vrouwen niet representatief is voor de jongere cohorten.

7. Om het onderscheid in de pensioenrechten zo scherp mogelijk te houden tussen werknemers die geboren zijn in 1949 of 1950 , blijven de mensen die onder een FLO regeling vallen, zoals degenen die werkzaam zijn bij de politie, brandweer of ambulancedienst evenals militair personeel, in dit onderzoek buiten beschouwing.

8. Het onderscheid in de pensioenrechten tussen werknemers die in 1949 en 1950 zijn geboren kan worden aangeduid als een 'natuurlijk experiment'. 
Dit rapport is als volgt opgebouwd. In hoofdstuk 2 wordt een overzicht gegeven van de pensioenverwachtingen van een representatieve steekproef van werknemers en de effectiviteit van een doorwerkbonus. Tevens wordt onderzocht in hoeverre gebrekkige financiële kennis problematisch kan zijn voor de pensioenverwachtingen en het spaargedrag. Hoofdstuk 3 gaat in op de effecten van de afschaffing van de FPU regeling en de geplande verhoging van de AOW leeftijd. In navolging op eerdere rapporten wordt geanalyseerd wat de gevolgen zijn van financiële prikkels op het verwachte uittredegedrag. Daarbij wordt ook de dynamiek in de pensioenverwachtingen voor de periode 2007-20II in kaart gebracht. Hoofdstuk 4 analyseert in hoeverre oudere werknemers minder gemotiveerd zijn voor hun werk en een lagere werkinzet hebben. Dit hoofdstuk geeft verder een beeld van de HR instrumenten die werkgevers volgens werknemers inzetten om hun inzetbaarheid op peil te houden. Bovendien wordt geanalyseerd in hoeverre deze door de werknemers gepercipieerde HR instrumenten daadwerkelijk kunnen bijdragen aan een verhoogde inzetbaarheid. Hoofdstuk 5 gaat vervolgens in op hoe de loonkosten en de productiviteit zich volgens werkgevers ontwikkelen met de leeftijd. Specifiek wordt aandacht besteed aan de voor-en nadelen die werkgevers ervaren om oudere werknemers te laten doorwerken en naar de mate waarin werkgevers leeftijdsdiscriminatie toepassen. In hoofdstuk 6 wordt het door de werkgever gepercipieerde personeelsbeleid in kaart gebracht. Specifiek wordt geanalyseerd welke HR instrumenten er worden ingezet en hoe werkgevers hun ouderenbeleid vormgeven. Hoofdstuk 7 combineert de percepties van werknemers en het oordeel werkgevers in één analyse. Aandacht wordt besteed aan de mate waarin percepties overeenkomen tussen de beide partijen en aan de vraag in welke sectoren werkgevers de ontevredenheid over het personeelsbeleid van hun eigen werknemers onderschatten. Vervolgens wordt ingegaan op de vraag in hoeverre de werkgeversantwoorden op de vragen met betrekking tot het personeelsbeleid en ouderenbeleid gecorreleerd zijn met het pensioengedrag en de werkinzet van de werknemers. In hoofdstuk 8 vatten wij de onderzoeksresultaten samen en worden enkele beleidsaanbevelingen gegeven. 


\section{Pensioenverwachtingen en spaargedrag}

In dit hoofdstuk zal een overzicht worden gegeven van de pensioenverwachtingen van een representatieve steekproef van werknemers die werkzaam zijn in de overheid, het onderwijs, in de bouw of woningcorporaties. In deze sectoren is in totaal ruim $27 \%$ van de beroepsbevolking in Nederland werkzaam. ${ }^{9}$ Het is relevant om een goed beeld te krijgen van deze verwachtingen, aangezien er in de afgelopen twee decennia diverse veranderingen zijn doorgevoerd die de pensioenrechten van werknemers in sterke mate hebben beïnvloed. Daardoor is het de vraag in hoeverre werknemers in staat zijn in deze sterk veranderende context hun pensioenrechten en uittredeleeftijd correct in te schatten.

Deze vraag is extra relevant voor jongere werknemers die niet onder transitieregelingen vallen die gepaard gaan met de afschaffing van de VUT en prepensioenregelingen en bovendien zwaarder worden getroffen door de invoering van het middelloonstelsel in $2004 .{ }^{\text {IO }}$

\subsection{Verwachtingen over pensioenuitkering}

Om te achterhalen wat de verwachtingen zijn van werknemers ten aanzien van hun pensioenuitkering is in de enquête de volgende vraag gesteld:

Stel, u zou met 62 jaar volledig met pensioen gaan, hoe hoog denkt $u$ dat uw jaarlijkse pensioenuitkering dan zal zijn? (in \% van uw netto salaris)

Figuur 2.I laat zien hoe mensen van verschillende leeftijden hierop geantwoord hebben in de sectoren overheid en onderwijs, bouw en woningcorporaties. Het blijkt dat

9. In 2009 omvatte de beroepsbevolking 7,8 miljoen mensen, waarvan 2,I miljoen werkte in de overheid en het onderwijs en in de bouw (CBS Statline, 20II).

IO. Tot I januari 2004 werd het pensioen van werknemers berekend op basis van hun laatst verdiende loon, wat voordelig is voor de meeste werknemers aangezien zij aan het eind van hun carrière ook aan het eind van hun loonschaal zitten, terwijl vanaf deze datum het pensioen wordt berekend op basis van het gemiddelde loon dat werknemers vanaf 2004 hebben verdiend.

II. Door de wijze waarop deze vraag is gesteld blijft deze informatie relevant voor de kleine groep werknemers die ouder is dan 62 jaar (omvang is circa $3 \%$ van de totale steekproef). 
werknemers verwachtingen hebben ten aanzien van hun pensioenuitkering die niet stroken met de feitelijke uitkering die zij zullen ontvangen. Dit geldt specifiek voor jongere werknemers in de sectoren overheid en het onderwijs, die een hogere pensioenuitkering verwachten te ontvangen dan de oudere werknemers in hun sector. ${ }^{12}$ Er is sprake van een significant dalende leeftijdstrend die impliceert dat een werknemer die één jaar jonger is een uitkering verwacht die 0,08\% hoger ligt dan degene die een jaar ouder is. Dit duidt erop dat het pensioensbewustzijn bij jongere cohorten werknemers in de overheid en het onderwijs nog niet in voldoende mate is ontwikkeld. Immers, het zijn juist de jongere cohorten die door de afschaffing van de prepensioenregelingen en de invoering van het middelloonstelsel lagere pensioenrechten hebben.

\section{Figuur 2.1}

Verwachte pensioenuitkering op 62-jarige leeftijd

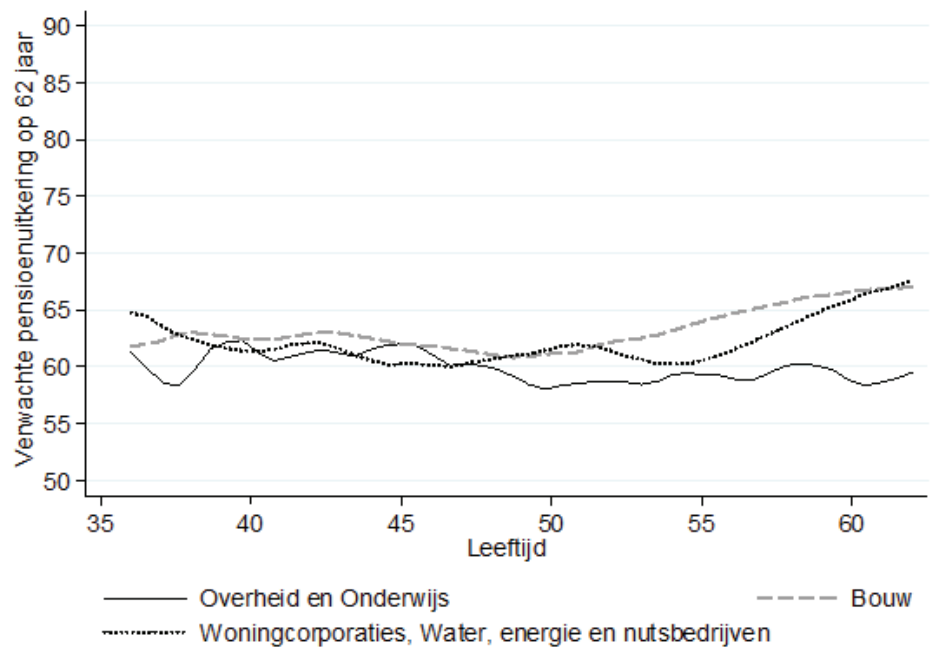

Er is wel een stijgende leeftijdstrend zichtbaar voor de bouw en de woningcorporaties. Jongere werknemers in de bouw en woningcorporaties denken een significant lagere pensioenuitkering te krijgen dan oudere werknemers. Correlatiecoëfficiënten laten zien dat een werknemer die één jaar jonger is ongeveer een 0,3\%-punt lagere pensioenuitkering verwacht te ontvangen. Voor de woningcorporaties zorgt een leeftijdsverschil van één jaar tot een verwachte pensioenuitkering die 0,6\%-punt lager is. Daarnaast blijkt dat werknemers in de bouw en woningcorporaties gemiddeld genomen een iets hogere uitkering denken te ontvangen dan degenen die werken in de overheid en het onderwijs. Gemiddeld genomen verwachten zij een uitkering

I2. Hierbij moet wel worden opgemerkt dat niet wordt gespecificeerd of het hier om het middelloon, eindeloon of huidige salaris gaat. Indien werknemers uitgaan van hun huidige salaris, zouden jongeren mogen verwachten dat dit later in hun loopbaan nog zal toenemen waardoor het pensioen in percentage van hun huidige inkomen hoger zou zijn. 
te ontvangen die $64, \mathrm{I} \%$, respectievelijk $62,3 \%$ bedraagt van hun netto salaris, tegen $59,7 \%$ voor degenen die in de overheid en het onderwijs werken.

\section{Tabel 2.1}

Verwachte pensioenuitkering op 62-jarige leeftijd naar sector

\begin{tabular}{|c|c|c|c|c|c|c|}
\hline & 35-44 jaar & $\begin{array}{l}\text { Sig verschil } \\
\text { tussen } \\
\text { sectoren }\end{array}$ & 45-54 jaar & $\begin{array}{l}\text { Sig verschil } \\
\text { tussen } \\
\text { sectoren }\end{array}$ & 55-64 jaar & $\begin{array}{l}\text { Sig verschil } \\
\text { tussen } \\
\text { sectoren }\end{array}$ \\
\hline Rijk & 59,6 & & 57,7 & & 60,8 & \\
\hline Defensie burgerpersoneel & 62,8 & & 69,2 & $* * *$ & 65,7 & $* *$ \\
\hline Provincies en Waterschappen & 57,4 & & 59,9 & & 59,9 & \\
\hline Gemeenten & 58,9 & & 59,8 & & 60,0 & \\
\hline Politie & 62,0 & & 65,8 & $* * *$ & 69,8 & $* * *$ \\
\hline Primair onderwijs & 61,8 & & 56,6 & & 60,0 & \\
\hline Voortgezet onderwijs & 67,0 & ** & 60,1 & & 57,2 & $* * *$ \\
\hline Hoger beroepsonderwijs & 51,4 & & 55,2 & & 57,7 & * \\
\hline $\begin{array}{l}\text { Wetenschappelijk onderwijs, } \\
\text { onderzoek en wetenschapsbeleid }\end{array}$ & 57,9 & & 54,1 & & 54,5 & $* * *$ \\
\hline Beroeps- en volwasseneneducatie & 64,7 & & 58,8 & & 56,9 & ** \\
\hline Universitaire medische centra & 51,8 & & 55,2 & & 54,8 & $* *$ \\
\hline Water, energie en nutsbedrijven & 66,9 & * & 60,4 & & 64,4 & * \\
\hline Vrijwillige toetreders & 58,5 & & 56,7 & & 56,4 & * \\
\hline Overig & 65,8 & & 61,5 & & 63,6 & \\
\hline Bouw & 62,5 & & 61,5 & $* *$ & 67,0 & $* * *$ \\
\hline Woningcorporaties & 54,3 & & 62,0 & & 63,8 & \\
\hline $\begin{array}{l}\text { Totaal } \\
=\text { significant op } 10 \% \text {-nive } \\
\text { Joor de wijze waarop dez } \\
\text { Nerknemers die ouder is da }\end{array}$ & $\begin{array}{l}60,5 \\
\text { significar } \\
\text { is gestel } \\
\text { ar (retrosk }\end{array}$ & $\begin{array}{l}\text { op 5\%-ni } \\
\text { blijft dez } \\
\text { ctieve inf }\end{array}$ & $\begin{array}{l}59,4 \\
\text { eau, } \\
\text { informat } \\
\text { rmatie). }\end{array}$ & $\begin{array}{l}\text { ignificant } \\
\text { relevant }\end{array}$ & $\begin{array}{l}60,1 \\
\text { p 1\%-nive } \\
\text { oor de k }\end{array}$ & $\begin{array}{l}\text { au. } \\
\text { aine groep }\end{array}$ \\
\hline
\end{tabular}

Tabel 2.I geeft een meer gedetailleerd beeld van de verwachte pensioenuitkering op 62-jarige leeftijd per sector en leeftijdscohorten, waarbij de overheid en het onderwijs worden uitgesplitst naar I4 sectoren. Het blijkt dat vooral jongere werknemers in het voortgezet onderwijs en in de sector water, energie en nutsbedrijven een optimistisch beeld hebben van hun pensioenrechten. $\mathrm{Zij}$ verwachten een uitkering van $67 \%$ van hun nettosalaris op 62-jarige leeftijd. Bij de oudere werknemers valt op dat werknemers in de bouw, de politie en defensie burgerpersoneel een relatief hoge pensioenuitkering verwachten. Daarentegen verwachten oudere werknemers die werkzaam zijn in het wetenschappelijk onderwijs, onderzoek en wetenschapsbeleid, universitaire medische centra en de beroeps- en volwasseneneducatie een significant lagere pensioenuitkering. 
Er zijn in de enquête ook vragen gesteld over de verwachte pensioenuitkering op 63- en 65-jarige leeftijd. Figuur 2.2 laat zien dat de verwachte pensioenuitkeringen op deze leeftijden goed corresponderen met de financiële prikkels die in het pensioensysteem zitten om het langer doorwerken te stimuleren. Werknemers verwachten dat zij een pensioenuitkering krijgen die 6,8\%-punt hoger ligt als zij hun pensioendatum uitstellen van 62 naar 63 jaar. Uitstel tot 65 jaar zou volgens de werknemers een uitkering opleveren die 16,6\%-punt hoger ligt. Additionele analyses wijzen uit dat jongere werknemers even goed op de hoogte zijn van de financiële prikkels in het pensioensysteem die tot langer doorwerken aanzetten dan oudere werknemers, ongeacht de sector waarin zij werkzaam zijn.

\section{Figuur 2.2}

Verwachte pensioenuitkering op 62-, 63- en 65-jarige leeftijd

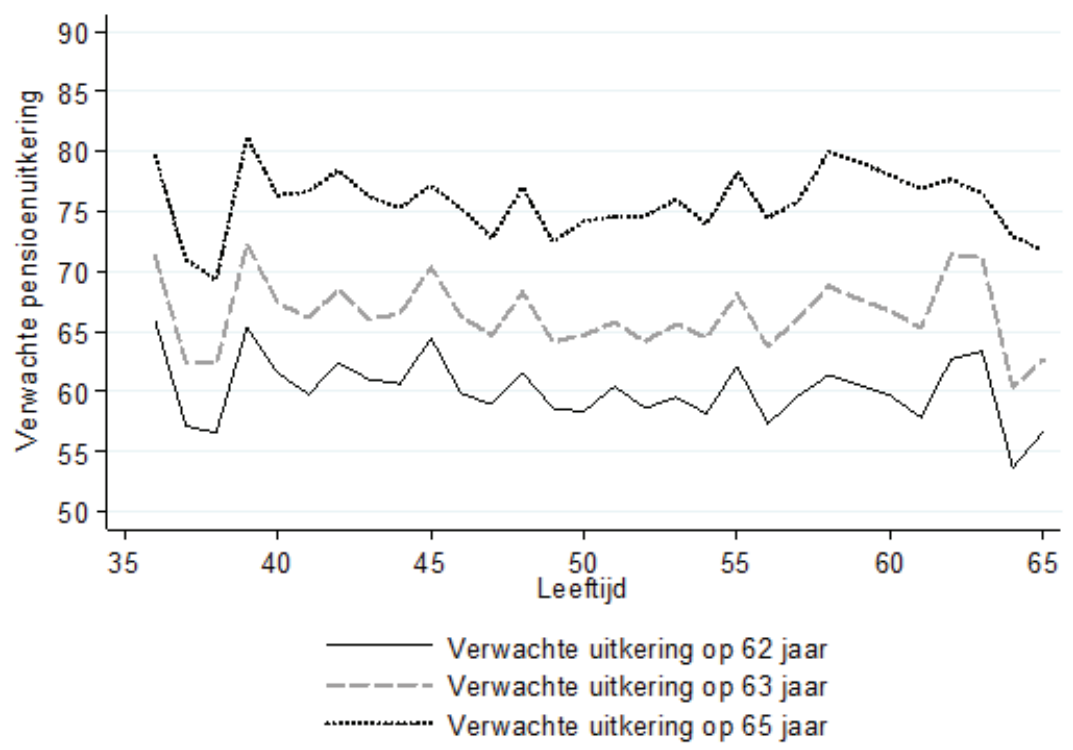

Figuur 2.3 geeft weer hoe de verwachte pensioenuitkering op 62-jarige leeftijd verschilt tussen mannen en vrouwen. Jongere vrouwen verwachten een uitkering die ongeveer gelijk is aan die van de mannen in dezelfde leeftijd. Vrouwen die ouder zijn dan 40 jaar denken echter een lagere uitkering te ontvangen dan de mannen in hetzelfde leeftijdscohort. Het verschil tussen mannen en vrouwen neemt significant toe naarmate het leeftijdscohort ouder is. Dit resultaat is consistent met het beeld dat oudere vrouwen meer en langere pensioenbreuken hebben gehad toen zij kinderen kregen, terwijl vrouwen in jongere cohorten na het krijgen van een kind vaker blijven werken of hun baan sneller weer oppakken. 
Verder laat figuur 2.4 zien dat laagopgeleide werknemers een hogere pensioenuitkering verwachten ten opzichte van hun netto salaris dan hoogopgeleide werknemers. Het is onduidelijk hoe dit resultaat geïnterpreteerd moet worden. Laagopgeleide werknemers hebben mogelijk minder kennis van het pensioensysteem, waardoor ze hun toekomstige pensioenuitkering te hoog inschatten. Echter, laagopgeleide werknemers beginnen ook eerder met werken waardoor zij dus langer pensioen opbouwen en derhalve een hogere pensioenuitkering in termen van hun nettosalaris krijgen. Daarnaast maakt de AOW uitkering een relatief groot deel uit van de totale uitkering die laagopgeleide werknemers met een laag salaris zal gaan ontvangen. Bovendien zal het salaris van laagopgeleide werknemers gemiddeld genomen minder snel stijgen naarmate zij ouder worden en zullen ook eerder tegen een salarisplafond oplopen waardoor het middelloonstelsel voor hen een minder groot effect zal hebben op de hoogte van hun pensioenuitkering. In paragraaf 2.5 zal geprobeerd worden om deze effecten van elkaar te onderscheiden.

Figuur 2.3

Verwachte pensioenuitkering op 62-jarige leeftijd naar geslacht

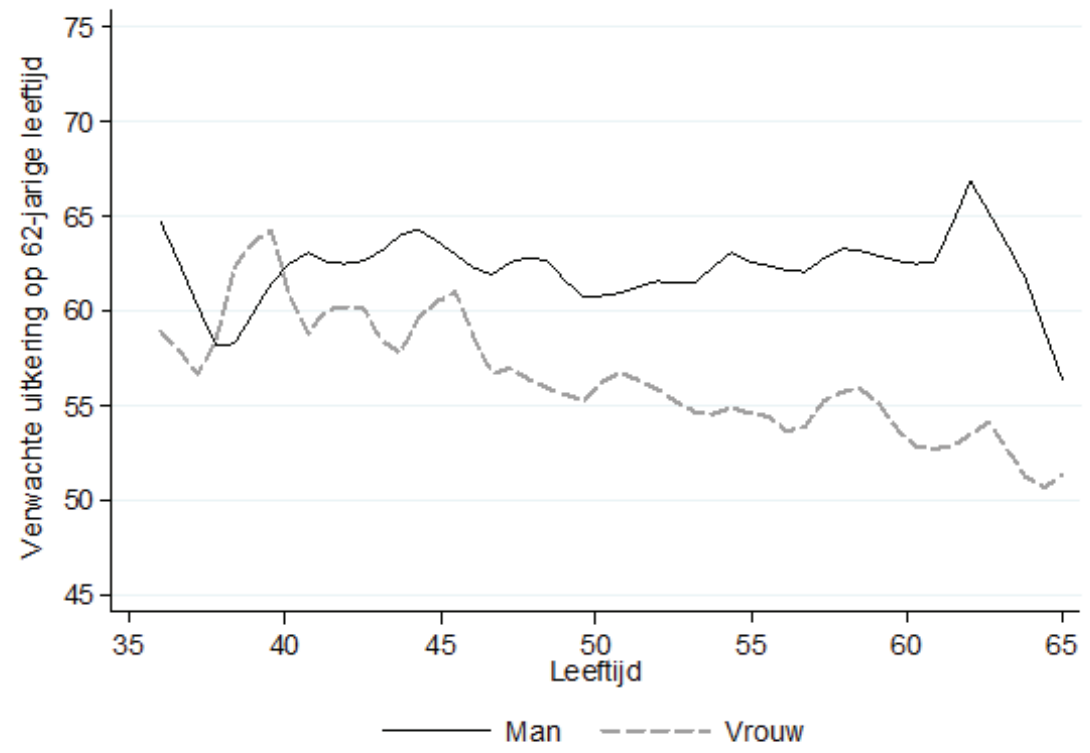


HOOFDSTUK 2

Figuur 2.4

Verwachte pensioenuitkering op 62-jarige leeftijd naar opleiding

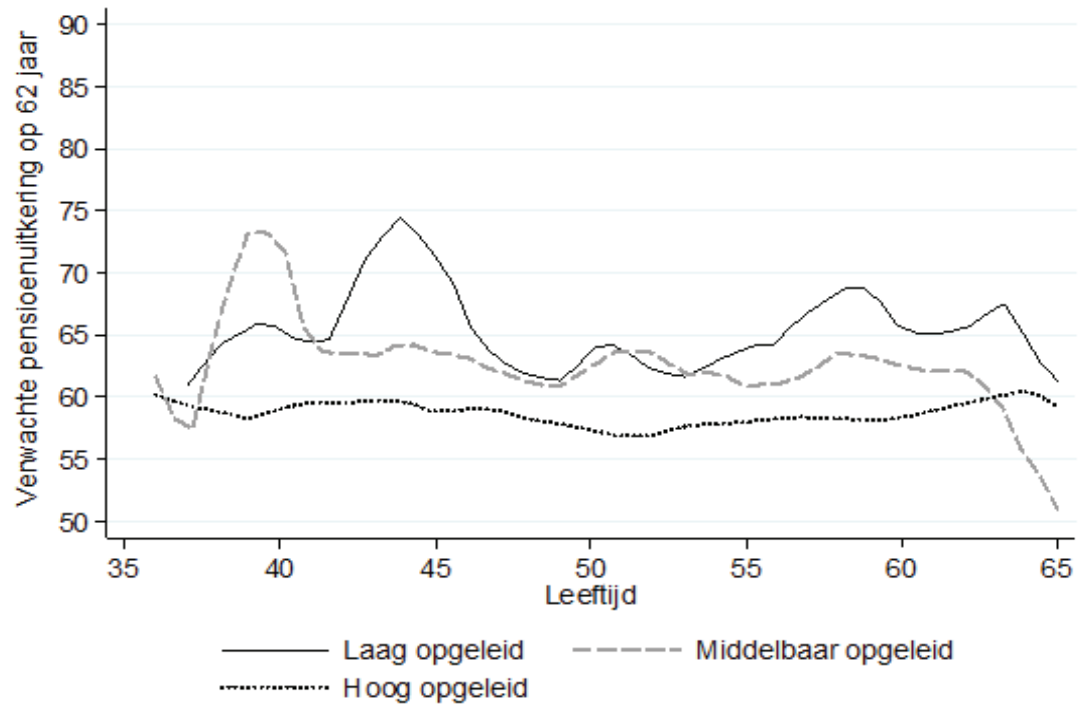

Figuur 2.5

Verwachte pensioenleeftijd

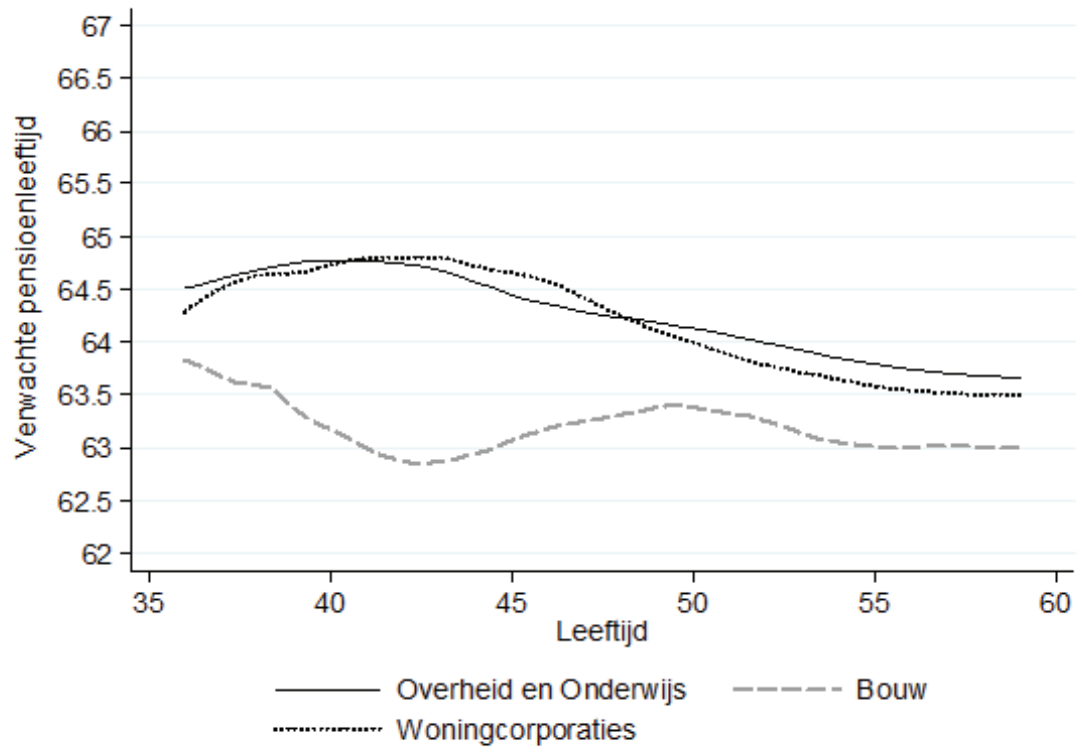




\subsection{Verwachte pensioenleeftijd}

In hoeverre vertalen de verschillen in de verwachte pensioenuitkering tussen de verschillende cohorten zich in verschillen in de verwachte pensioenleeftijd. Figuur 2.5 laat zien hoe werknemers hebben geantwoord op de vraag:

Op welke leeftijd denkt u volledig te stoppen met werken? ${ }^{\text {t3 }}$

Uit de figuur blijkt dat werknemers die werkzaam zijn bij de overheid, het onderwijs of de woningcorporaties, gemiddeld genomen verwachten dat ze op 64 jarige leeftijd volledig zullen stoppen met werken. In deze sectoren denken jongere medewerkers later uit te treden dan de ouderen. Werknemers bij de overheid en in het onderwijs die tussen de 35 en 44 jaar oud zijn, denken ongeveer een half jaar langer door te gaan werken dan degenen die tussen de 45 en 54 jaar oud zijn. Bij woningcorporaties vinden we eveneens dat jongere werknemers later denken uit te treden. Werknemers in de bouw denken gemiddeld genomen op 63-jarige leeftijd met hun werk te stoppen. Daarmee verwachten zij dus één jaar eerder met pensioen te gaan dan degenen die bij de overheid, het onderwijs en de woningcorporaties werken. Daarbij vinden we voor de bouw geen lagere verwachte pensioenleeftijd naarmate werknemers ouder zijn.

Tabel 2.2. laat zien dat de verwachte pensioenleeftijd in de bouw inderdaad significant lager is dan in de andere sectoren. Hiermee speelt ongetwijfeld mee dat veel werknemers in deze sector zware beroepen hebben en fysiek niet in staat zullen zijn om in hun huidige functie door te blijven werken tot hun 65 ste. Ook blijkt dat de verwachte pensioenleeftijd lager is voor degenen die werkzaam zijn bij defensie of de politie. Ook in deze sectoren is er vaak sprake van zware beroepen waarin traditiegetrouw additionele pensioenregelingen worden gehanteerd die het mogelijk maken om vroeger met werken te kunnen stoppen. Opvallend is echter dat ook jongere werknemers in de leeftijd van 35-44 jaar in het primair onderwijs significant eerder denken met pensioen te gaan dan werknemers met dezelfde leeftijd in andere sectoren. Dit duidt mogelijk op een te optimistische kijk op de pensioenproblematiek van de jongere werknemers in deze sector. Werknemers in het wetenschappelijk onderwijs, onderzoek en wetenschapsbeleid en het hoge beroepsonderwijs denken daarentegen significant later met pensioen te gaan.

I3. De analyses op de verwachte pensioenleeftijd zijn beperkt tot werknemers die jonger dan 60 jaar zijn. 
Tabel 2.2

Verwachte pensioenleeftijd naar sector

\begin{tabular}{|c|c|c|c|c|}
\hline & 35-44 jaar & $\begin{array}{l}\text { Sig verschil tussen } \\
\text { sectoren }\end{array}$ & 45-54 jaar & $\begin{array}{l}\text { Sig verschil tussen } \\
\text { sectoren }\end{array}$ \\
\hline Rijk & 65,4 & & 64,4 & \\
\hline Defensie burgerpersoneel & 61,1 & $* * *$ & 60,7 & $* * *$ \\
\hline Provincies en Waterschappen & 66,0 & & 64,8 & \\
\hline Gemeenten & 64,9 & & 64,3 & \\
\hline Politie & 63,9 & $* *$ & 63,7 & \\
\hline Primair onderwijs & 64,2 & $* *$ & 64,0 & \\
\hline Voortgezet onderwijs & 64,6 & & 64,7 & \\
\hline Hoger beroepsonderwijs & 65,7 & & 64,8 & \\
\hline $\begin{array}{l}\text { Wetenschappelijk onderwijs, onderzoek } \\
\text { en wetenschapsbeleid }\end{array}$ & 65,3 & & 65,7 & $* * *$ \\
\hline Beroeps- en volwasseneneducatie & 65,9 & & 63,8 & \\
\hline Universitaire medische centra & 65,6 & & 64,2 & \\
\hline Water, energie en nutsbedrijven & 64,4 & & 64,2 & \\
\hline Vrijwillige toetreders & 64,0 & $*$ & 65,0 & \\
\hline Overig & 65,8 & & 64,6 & \\
\hline Bouw & 62,9 & $* * *$ & 63,4 & $* * *$ \\
\hline Woningcorporaties & 66,3 & & 63,6 & \\
\hline $\begin{array}{l}\text { Totaal } \\
\text { Rijk is referentiekader } \\
\text { * = significant op 10\%-niveau, }\end{array}$ & ificant c & niveau, ${ }^{* * *}=$ & ficant or & niveau. \\
\hline
\end{tabular}

De Figuren 2.6 - 2.7 geven een beeld van de spreiding van de verwachte pensioenleeftijden voor de leeftijdscohorten 35-44 en 45-54 jarigen. Het blijkt dat de spreiding van de pensioenleeftijd voor jongeren veel groter is dan voor het oudere cohort. Dit valt ook te verwachten, aangezien het pensioen van jongeren ook met veel meer onzekerheden is omgeven en jongeren doorgaans minder goed geïnformeerd zijn over hun pensioen. Werknemers die tussen de 35 en 44 jaar oud zijn denken vaak met pensioen te gaan op 65- of 67-jarige leeftijd. Ook veel werknemers die tussen de 45 en 54 jaar zijn denken op deze leeftijden met pensioen te gaan. Echter, de piek voor 65 jaar is hier beduidend groter, terwijl die voor 67 jaar juist kleiner is. 
Figuur 2.6

Verwachte pensioenleeftijd van $35-44$ jarigen

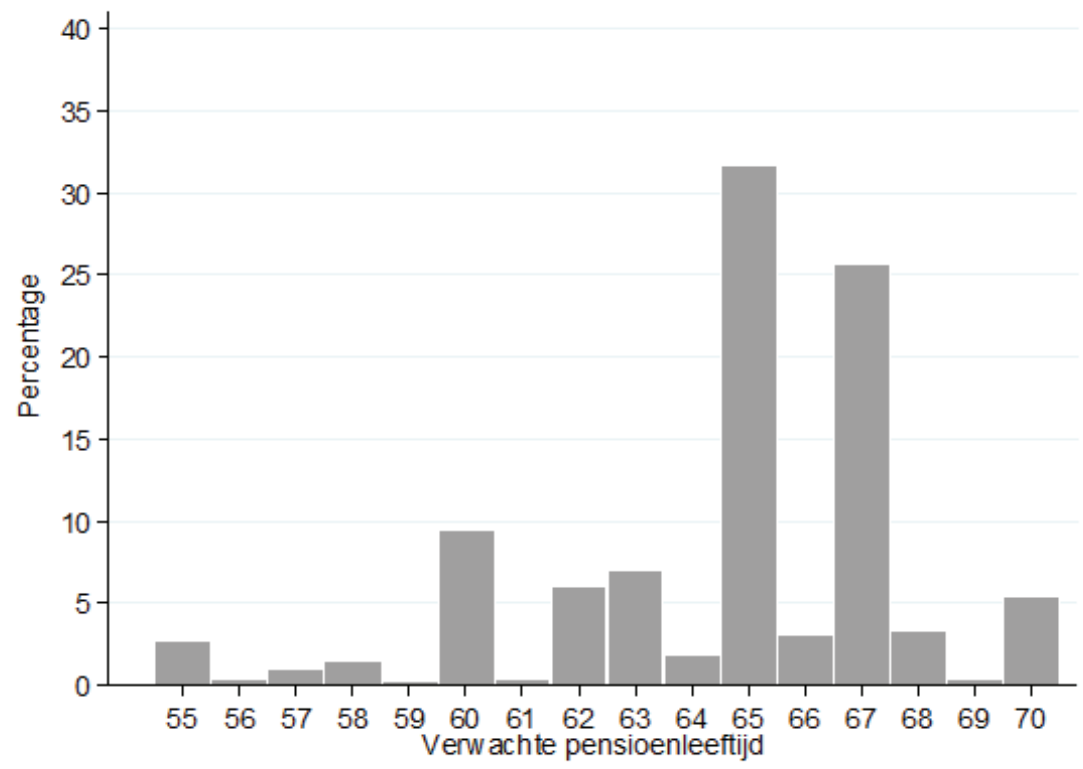

Figuur 2.7

Verwachte pensioenleeftijd van 45-54 jarigen

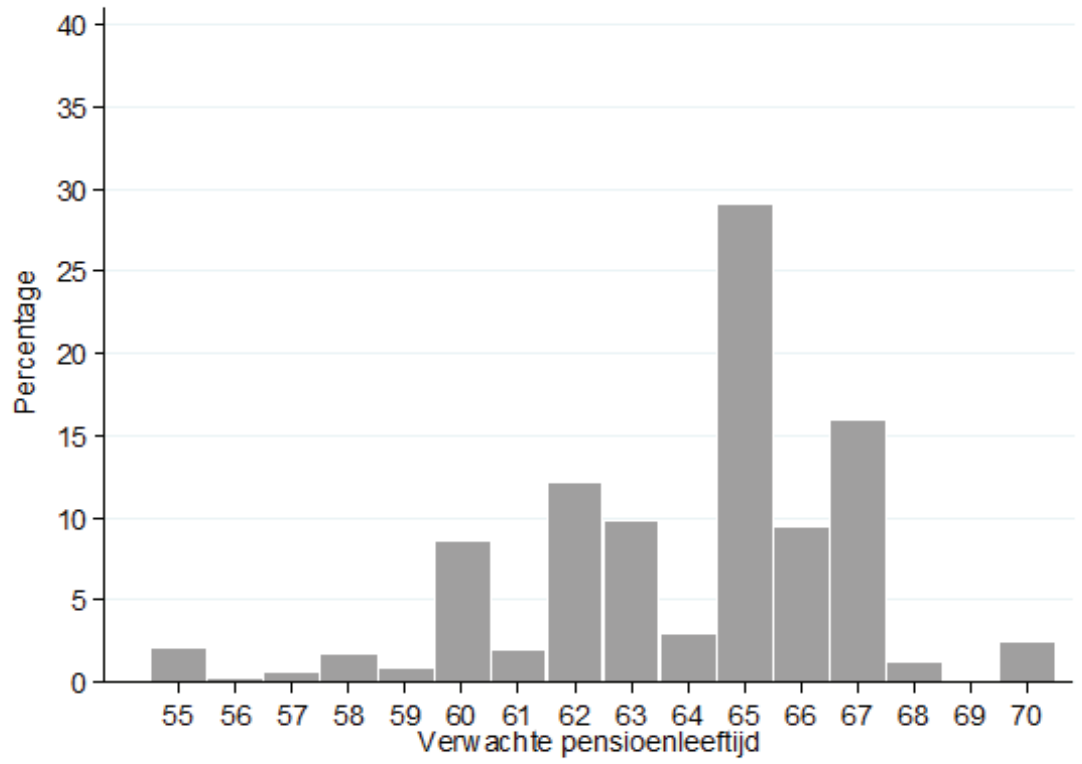


HOOFDSTUK 2

Figuur 2.8

Verwachte pensioenleeftijd naar geslacht

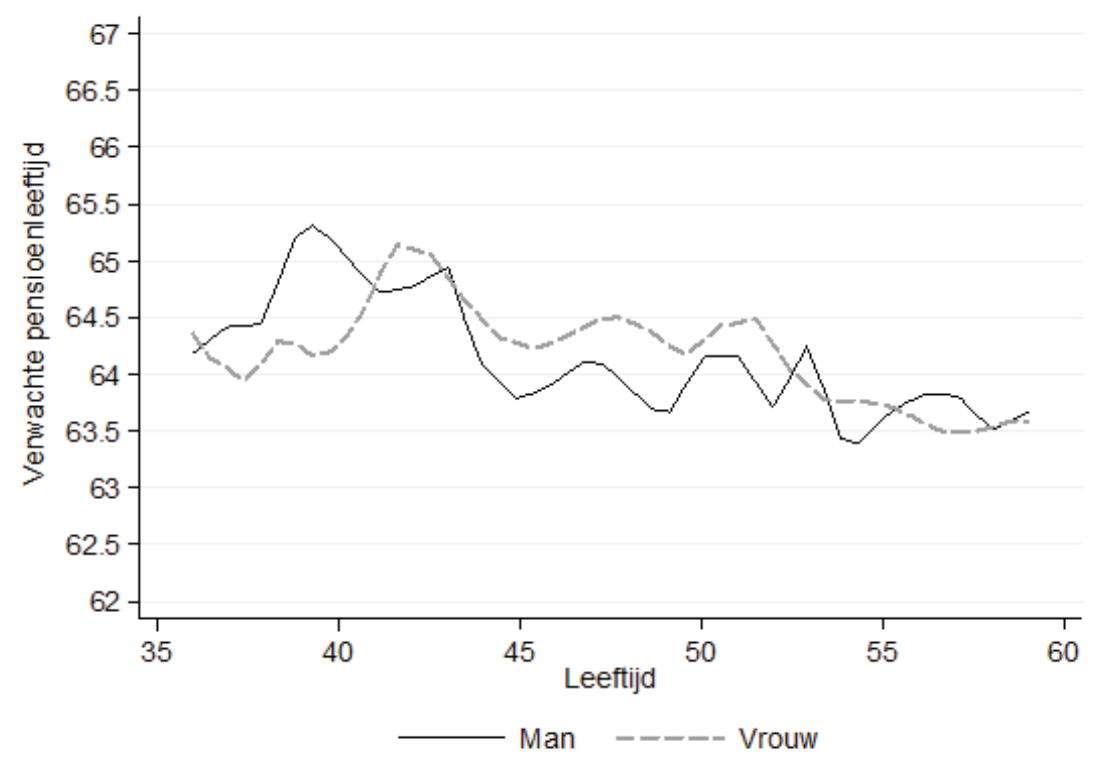

Figuur 2.9

Verwachte pensioenleeftijd naar opleiding

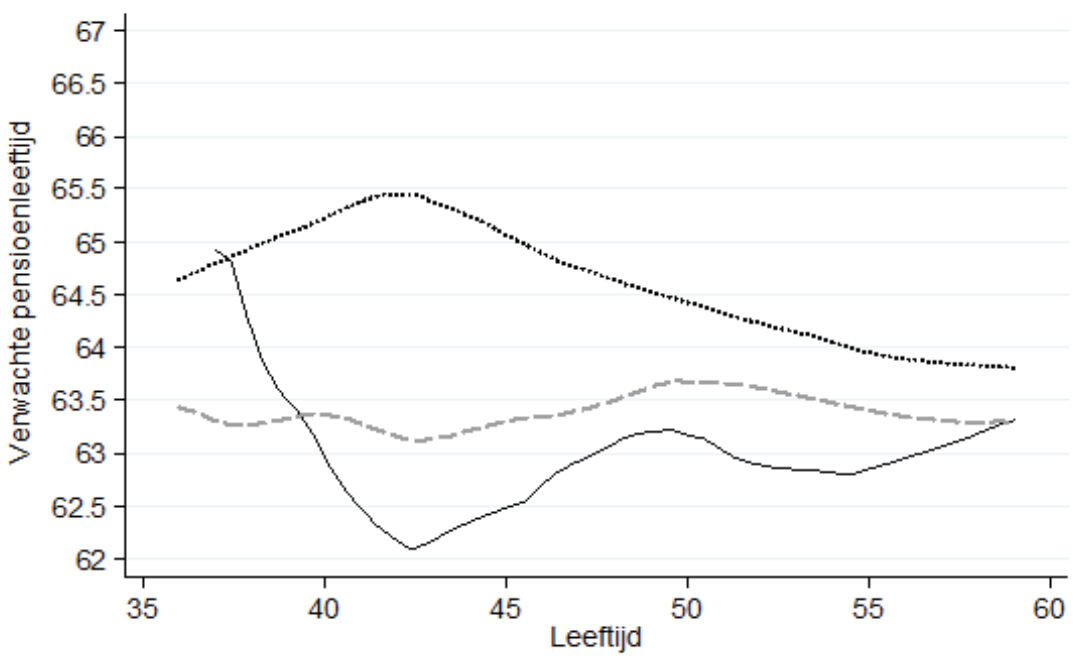


Uit figuur 2.8 blijkt dat de verwachte pensioenleeftijd van mannen en vrouwen nauwelijks van elkaar verschilt, ondanks het feit dat de verwachte pensioenuitkering wel sterk van elkaar verschilt. Ten slotte laat figuur 2.9 zien dat laagopgeleide werknemers eerder met pensioen denken te gaan dan hoogopgeleiden. Deze verwachting is consistent met de hogere pensioenuitkering die zij verwachten ten opzichte van hun netto salaris. Echter ook hier geldt dat onduidelijk is hoe dit resultaat geïnterpreteerd moet worden. Het is de vraag in hoeverre laagopgeleiden in vergelijking met hun salaris betere pensioenrechten hebben, of dat zij op zowel het gebied van verwachte pensioenuitkeringen als op de verwachte pensioenleeftijd te optimistisch zijn.

\subsection{Deeltijdpensionering}

Successievelijke hervormingen van het pensioenstelsel zorgen ervoor dat werknemers steeds meer flexibiliteit krijgen in hun uittredebesluit. Een goed voorbeeld van deze toegenomen flexibiliteit is de introductie van deeltijdpensionering die het mogelijk maakt dat werknemers in deeltijd blijven doorwerken, terwijl zij voor de resterende uren pensioen ontvangen. Voor veel (jongere) werknemers met lage pensioenrechten zal een volledige uittrede voor hun 65e financieel niet meer haalbaar zijn. Deeltijdpensioen kan voor deze werknemers echter een aantrekkelijke optie zijn om alsnog gedeeltelijk een vervroegde uittrede te bewerkstelligen.

Tabel 2.3

Deeltijdpensionering

\begin{tabular}{lccc|} 
& $35-44$ & $45-54$ & $55-65$ \\
\hline Van plan om met deeltijdpensioen te gaan & $44,0 \%$ & $40,0 \%$ & $27,1 \%$ \\
\hline Leeftijd waarop men van plan is om met deeltijdpensioen te gaan & 60,8 & 60,8 & 61,8 \\
\hline Duur deeltijdpensionering (in jaren) & 3,7 & 3,0 & 1,8 \\
\hline Aantal dagen dat mensen met deeltijdpensioen willen & 1,6 & 1,7 & 1,8
\end{tabular}

Tabel 2.3 laat zien dat jongere werknemers inderdaad vaker denken van deeltijdpensionering gebruik te gaan maken. Terwijl $44 \%$ van de werknemers in de leeftijd van 35 tot 44 jaar denkt gebruik te maken van deeltijdpensionering, is dit bij de 55-plussers slechts bij $27 \%$ het geval. Jongere werknemers denken ook één jaar eerder met deeltijdpensioen te gaan dan oudere werknemers. Dit duidt erop dat zij deeltijdpensionering zien als een alternatieve route om alsnog op een bepaalde manier vervroegd uit te treden. Opmerkelijk daarbij is dat jongeren ook verwachten dat zij langer gebruik zullen maken van deeltijdpensionering. Werkenden in de leeftijd van 35 tot en met 44 jaar verwachten meer dan 3,5 jaar gebruik te maken van deeltijdpensioen, tegenover I,8 jaar bij de 55-plussers. Echter, de jongere werknemers verwachten slechts twee maanden later definitief te stoppen met werken dan de 55-plussers. Overigens denken de jongere werknemers gemiddeld ongeveer I,6 dag met deeltijdpensioen te kunnen gaan, terwijl de oudere werknemers verwachten dat zij nauwelijks meer deeltijdpen- 
sioen kunnen opnemen ( $\mathrm{I}, 8 \mathrm{dag}$ ). Dit alles roept de vraag op of het jongere cohort niet te optimistisch is over de periode waarin zij met deeltijdpensioen kunnen gaan.

Figuur 2.Io bevestigt het beeld uit tabel 2.3. Er is duidelijk sprake van een negatieve leeftijdstrend in het percentage werknemers dat met deeltijdpensioen denkt te gaan. De figuur laat ook zien dat dit percentage niet significant verschilt tussen de overheid en onderwijs, de bouw en de woningcorporaties.

\section{Figuur 2.10}

Deeltijdpensionering

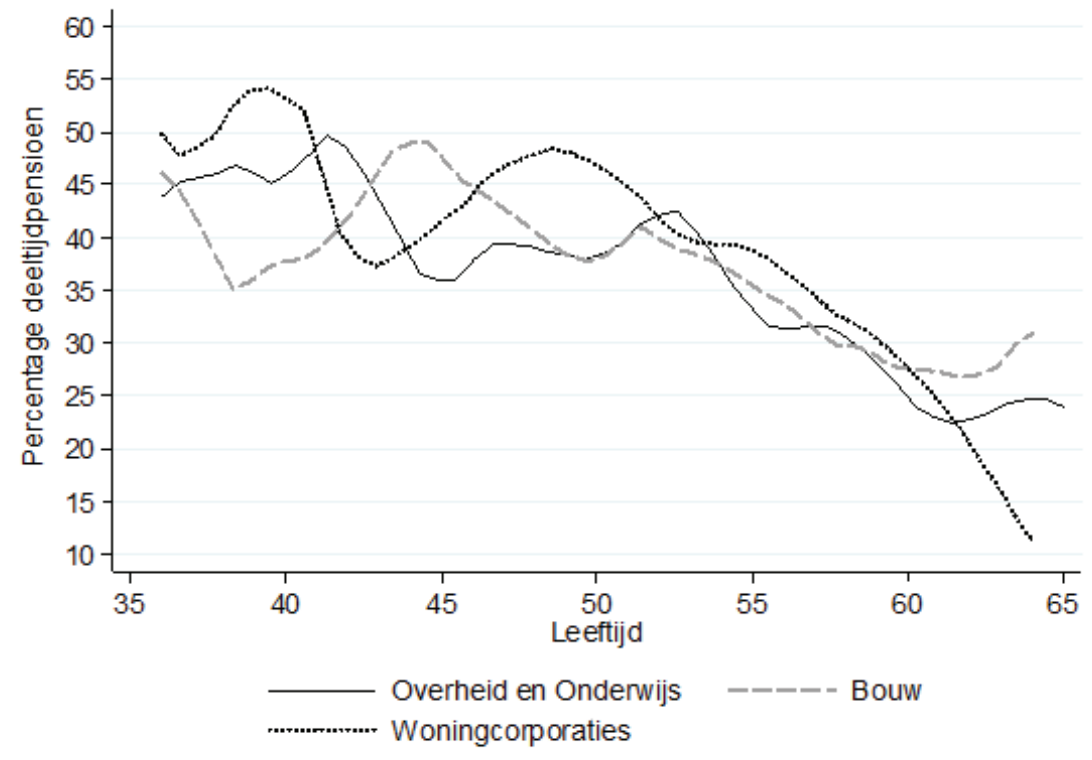

Uit figuur 2.II blijkt verder dat vrouwen in de oudere leeftijdsgroepen minder vaak denken gebruik te zullen maken van deeltijdpensionering dan mannen. Dit wordt grotendeels veroorzaakt doordat vrouwen in deze cohorten reeds vaak in deeltijd werken, terwijl mannen een voltijdbaan hebben. Daarentegen zijn er op dit punt bij de jongere cohorten geen significante verschillen tussen mannen en vrouwen. Dit komt waarschijnlijk deels doordat vrouwen in deze cohorten meer nadruk op hun loopbaan leggen. Anderzijds geldt ook dat zowel mannen als vrouwen in de jongere cohorten vaker van deeltijdpensioen denken gebruik te maken dan oudere werknemers. Dit duidt erop dat jongere werknemers, ongeacht hun geslacht, deeltijdpensionering als een aantrekkelijk alternatief zien voor een volledige arbeidsmarktuittrede, waarschijnlijk omdat volledige pensionering op jonge leeftijd voor deze groep financieel onhaalbaar is. 
Figuur 2.11

Deeltijdpensionering naar geslacht

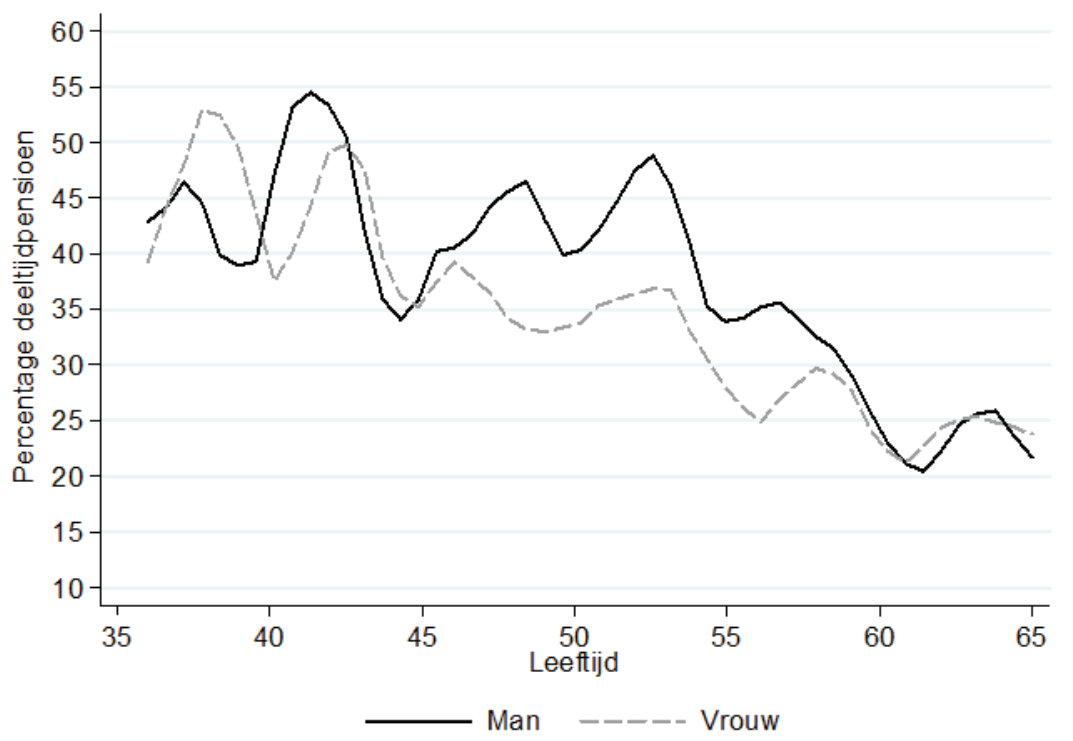

\subsection{Eigen pensioenvoorzieningen}

De versoberingen van de pensioenrechten in de eerste en tweede pijler van het pensioensysteem zouden vooral jongere werknemers moeten stimuleren om hun pensioen individueel aan te vullen door middel van producten die onder de derde pijler van het pensioenstelsel vallen. Tabel 2.4 laat echter zien dat jongere werknemers nauwelijks anticiperen op het feit dat zij lagere pensioenrechten hebben. Gemiddeld genomen heeft maar $37,4 \%$ van alle 35-44 jarigen extra geïnvesteerd in hun pensioen. De werknemers tussen de 45 en 55 jaar zijn het vaakst gaan bijsparen (44,9\%). Bij de $55+$ ers is dit percentage wat lager $(42,3)$. Dit laatste is echter weinig verrassend, aangezien deze leeftijdsgroep vaak nog gebruik kan maken van de oude genereuze vroegpensioenregelingen.

Van de personen die een eigen voorziening hebben getroffen, heeft ongeveer $55 \%$ een lijfrentepolis. $25 \%$ belegt en ongeveer $\mathrm{I} 5 \%$ heeft een koopsompolis. Interessant is dat lijfrentepolissen en koopsompolissen voornamelijk populair zijn bij oudere werknemers. Jongere werknemers nemen daarentegen iets vaker meer risico's door te investeren via beleggingen. 
Tabel 2.4

Eigen pensioenvoorzieningen

\begin{tabular}{lccc} 
& $35-44$ & $45-54$ & $55-65$ \\
& $\%$ & $\%$ & $\%$ \\
\hline Percentage met eigen voorzieningen & 37,4 & 44,9 & 42,3 \\
\hline Waarvan: & & & \\
\hline Lijfrentepolissen & 52,2 & 56,1 & 59,9 \\
\hline Koopsompolissen & 13,3 & 17,5 & 20,5 \\
\hline Inkoop pensioenrechten bij werkgever & 3,9 & 3,6 & 3,2 \\
\hline Extra periodieke betalingen bij werkgever & 1,1 & 2,9 & 3,3 \\
\hline Beleggingen & 26,7 & 25,8 & 22,7
\end{tabular}

\subsection{Financiële kennis en pensioenverwachtingen}

Uit de voorafgaande analyses is gebleken dat laagopgeleide werknemers een hogere pensioenuitkering verwachten en tevens eerder denken met werken te stoppen dan hoger opgeleiden. Deze verwachtingen stroken met het feit dat laagopgeleide werknemers eerder beginnen met werken, waardoor zij dus langer pensioen kunnen opbouwen. De kans bestaat echter ook dat deze werknemers een beperkte kennis hebben van financiële zaken en daarom hun toekomstige pensioenuitkering te hoog inschatten. Om deze effecten van elkaar te onderscheiden hebben wij regressiemodellen geschat waarin zowel het opleidingsniveau als een indicator voor de financiële kennis van respondenten als verklarende variabelen voor de pensioenverwachtingen zijn opgenomen. Deze indicator voor iemands financiële kennis wordt ontleend aan een module uit de Health en Retirement Study (2004) en is gevalideerd door Lusardi en Mitchell (2007) en Lusardi en Mitchell (2008). ${ }^{I 4}$ Deze 'financial literacy' variabele is gebaseerd op de volgende drie vragen:

I. Stel, $u$ heeft Ioo euro op uw spaarrekening en de rente is $2 \%$ per jaar, hoeveel geld denkt $u$ dat u op uw spaarrekening zou hebben na sjaar als u geen geld opnam van deze rekening?

\section{Minder dan I02 euro / Exact I02 euro / Meer dan I02 euro}

2. Stel, de rente op uw spaarrekening bedraagt I\% per jaar en de inflatie bedraagt $2 \%$ per jaar, hoeveel kunt $u$ dan na I jaar kopen met het geld op uw spaarrekening?

I4. A. Lusardi en O. Mitchell (2007), 'Financial Literacy and Retirement Preparedness. Evidence and Implications for Financial Education,' Business Economics, pp 35-44.

A. Lusardi en O. Mitchell (2008), 'Planning and Financial Literacy: How Do Women Fare?' American Economic Review, Vol. 98(2), pp 4I3-I7. 


\section{Minder / Exact hetzelfdel Meer}

3. Denkt $u$ dat de volgende stelling waar of niet waar is?

Het kopen van een aandeel van één bedrijf levert doorgaans een veiliger rendement op dan een aandeel van een gemeenschappelijk beleggingsfonds

\section{Waar / Niet waar}

Respondenten worden als financieel kundig beschouwd als zij alle drie de vragen correct hebben beantwoord. In totaal kan $86,4 \%$ van alle respondenten als financieel kundig worden beschouwd op basis van deze maatstaf. Hiermee zijn respondenten van onze survey relatief financieel kundig in vergelijking tot de rest van Nederland. Maar 4,0\% van de respondenten op onze survey gaf een fout antwoord op de eerste vraag, en $5,8 \%$ en $5,6 \%$ gaf een fout antwoord op de tweede en derde vraag. Van Rooij et al. (2OII) vinden dat deze percentages respectievelijk 5,2\%, I9,6 en $8,6 \%$ bedragen voor een representatieve steekproef van de gehele Nederlandse bevolking. ${ }^{\text {Is }}$ Een mogelijke verklaring hiervoor is dat er relatief veel hoog opgeleiden werkzaam zijn bij de overheid en het onderwijs.

De tabellen 2.5 en 2.6 laten zien dat werknemers die financieel kundig zijn, gemiddeld genomen vier maanden langer denken door te werken. Interessant is daarbij dat het opleidingseffect op de pensioenleeftijd niet meer statistisch significant is zodra wordt gecorrigeerd voor de financiële kennis van respondenten. Dit duidt erop dat de lage verwachte pensioenleeftijd onder laagopgeleiden samenhangt met het feit dat zij minder kennis hebben van financiële zaken dan hoger opgeleiden.

\section{Tabel 2.5}

Relatie tussen financiële kennis en pensioenverwachtingen

\begin{tabular}{|lllll|} 
& $\begin{array}{l}\text { Verwachte } \\
\text { pensioenleeftijd }\end{array}$ & $\begin{array}{l}\text { Uitkering op } \\
62 \text { jaar }\end{array}$ & $\begin{array}{l}\text { Uitkering op } \\
63 \text { jaar }\end{array}$ & $\begin{array}{l}\text { Uitkering op } \\
65 \text { jaar }\end{array}$ \\
\hline Financiële kundig & $-0,309^{* * *}$ & 0,379 & 0,173 & 0,545 \\
\hline N & 3.981 & 3.669 & 3.679 & 3.697
\end{tabular}

Controlevariabelen: leeftijd, opleidingsniveau, sectoren, inkomen, deeltijdfactor, aantal contributiejaren

$*$ = significant op $10 \%$-niveau, ${ }^{* *}=$ significant op $5 \%$-niveau, ${ }^{* * *}=$ significant op $1 \%$-niveau.

I5. M. Van Rooij, A. Lusardi, R. Alessie (20II), 'Financial literacy and stock market participation', Journal of Financial Economics, Vol. IOI,(2), pp 449-472. 
Tabel 2.6

Relatie tussen financiële kennis en keuze voor aanvullende pensioenvoorzieningen

\begin{tabular}{lllll} 
& $\begin{array}{l}\text { (1) } \\
\text { Levensloop }\end{array}$ & $\begin{array}{l}\text { (2) } \\
\text { Deeltijd } \\
\text { pensioneren }\end{array}$ & $\begin{array}{l}\text { Eigen pensioen- } \\
\text { voorziening }\end{array}$ & $\begin{array}{l}\text { Waarde eigen } \\
\text { pensioenvoorziening }\end{array}$ \\
\hline Financiële kundig & $-0,019$ & $-0,056$ & $-0,005$ & $0.777^{* * *}$ \\
N & 3.977 & 3.988 & 3.988 & 1.365 \\
Controlevariabelen: Opleidingsniveau, sectoren, inkomen, deeltijdfactor, aantal contributiejaren \\
* = significant op 10\%-niveau, ${ }^{* *}=$ significant op $5 \%$-niveau, ${ }^{* * *}=$ significant op $1 \%$-niveau.
\end{tabular}

Daarentegen vinden we geen relatie tussen iemands financiële kennis en de verwachte uitkeringshoogte. Ook is het opvallend dat werknemers met meer financiële kennis niet meer zijn gaan bijsparen via de levensloopregeling, niet vaker denken gebruik te maken van deeltijdpensionering, en evenmin minder vaak privaat extra pensioenproducten hebben aangeschaft. Daarentegen zien we wel dat als werkenden met meer financiële kennis aanvullende pensioenvoorzieningen hebben getroffen, dat zij meer investeren in deze private voorzieningen. De waarde van de eigen pensioenvoorziening is significant hoger voor financieel kundige werknemers (ruim $77 \%$-punt). Interessant is dat we daarbij hebben gecontroleerd voor inkomen dat grotendeels vermogenseffecten zal oppakken (mensen met meer vermogen kunnen ook meer sparen).

Samengevat valt uit deze analyses te concluderen dat meer financiële kundigheid leidt tot minder optimistische verwachtingen ten aanzien van de pensioenleeftijd. Meer financiële kundigheid leidt er echter niet toe dat mensen vaker aanvullende pensioenproducten aanschaffen, maar wel dat zij meer investeren zodra zij een pensioenproduct aanschaffen (zie tabel 2.4 voor een overzicht van de pensioenvoorzieningen waarin wordt geïnvesteerd).

\subsection{Effectiviteit bonus om langer door te werken}

Ten slotte is er gekeken naar de mate waarin een doorwerkbonus effectief is om werknemers te stimuleren om hun arbeidsmarktuittrede uit te stellen. Om dit vast te kunnen stellen is de volgende vraag gesteld:

Stel, u krijgt een jaarlijkse netto bonus van ... euro aangeboden om langer door te werken. Zou u voor deze bonus langer doorwerken?

De respondenten kregen in deze vraag een bonus te zien van $€ 2.400, € 3500$ of $€$ 4.700. Deze bedragen komen overeen met de heffingskorting voor de inkomstenbelasting die door de overheid in 2009 is geïntroduceerd en als doorwerkbonus dient. Uit tabel 2.7 blijkt dat $22,5 \%$ van de werknemers langer zou doorwerken als zij een bonus krijgen van $€ 2.400$. Het is weinig verrassend dat een hogere bonus leidt tot een hoger percentage werknemers dat zich gestimuleerd voelt om door te werken. Interessant is 
echter dat een hogere doorwerkbonus weliswaar meer mensen motiveert om langer door te werken, maar ook dat deze groep gemiddeld veel minder lang wil doorwerken dan degenen die ook tegen een lagere bonus bereid waren om hun arbeidsmarktuittrede uit te stellen. Een bonus van $€ 2.400$ leidt ertoe dat werknemers I6,7 maanden langer willen doorwerken, terwijl bij een bonus van $€ 4,700$ werknemers gemiddeld genomen verwachten dat ze maar I4,5 maanden langer door werken. Wellicht heeft dit te maken met het feit dat gemotiveerde werknemers al bij een betrekkelijk laag doorwerkbonus bereid zijn om langer te werken. Het inkomenseffect dat uitgaat van een hoger doorwerkbonus stimuleert ook een groep werknemers dat minder gemotiveerd is om langer te werken. Dit resulteert er in dat er per saldo gemiddeld minder lang wordt doorgewerkt. Dit roept de vraag op in hoeverre de kosten van een hogere doorwerkbonus de baten zullen overtreffen.

Dat de doorwerkbonus maar in beperkte mate effectief is als middel om een hogere arbeidsparticipatie te bewerkstelligen is eveneens vastgesteld door Euwals et al. (2009). ${ }^{16} \mathrm{Zij}$ constateren dat vooral de gezonde ouderen met goede banen langer werken en de bonussen van de overheid ontvangen. De subsidie impliceert daardoor een perverse herverdeling van arm naar rijk. Daarnaast impliceert de subsidie herverdeling van jong naar oud waardoor de financiële druk op jongeren toeneemt. $\mathrm{Zij}$ vinden dat de participatie van mensen in de leeftijdsgroep 6o-64 stijgt met maar 0,6\%-punt door de bonus. Dit is echter het partiële effect, ofwel er wordt geen rekening gehouden met de financiering van de maatregel.

Tabel 2.7

Effectiviteit doorwerkbonus

\begin{tabular}{llll|} 
& $€ 2.400$ & $€ 3.500$ & $€ 4.700$ \\
\hline Langer doorwerken & $22,5 \%$ & $27,7 \%$ & $30,8 \%$ \\
\hline Aantal maanden langer doorwerken & 16,7 & 15,2 & 14,5
\end{tabular}

I6. R. Euwals, R. de Mooij en D. van Vuuren (2009), Rethinking Retirement: From participation towards allocation, CPB Special Publication No. 80, Den Haag. 
Tabel 2.8

Percentage werkenden dat langer wil werken bij een doorwerkbonus naar sector

\begin{tabular}{|c|c|c|}
\hline & $\%$ & $\begin{array}{l}\text { Sig. verschil } \\
\text { tussen sectoren }\end{array}$ \\
\hline Rijk & 24,7 & \\
\hline Defensie burgerpersoneel & 35,2 & $* * *$ \\
\hline Provincies en Waterschappen & 21,2 & \\
\hline Gemeenten & 28,4 & \\
\hline Politie & 27,9 & \\
\hline Primair onderwijs & 26,7 & \\
\hline Voortgezet onderwijs & 27,3 & \\
\hline Hoger beroepsonderwijs & 37,4 & *** \\
\hline Wetenschappelijk onderwijs, onderzoek en wetenschapsbeleid & 32,6 & ** \\
\hline Beroeps- en volwasseneneducatie & 23,8 & \\
\hline Universitaire medische centra & 32,6 & * \\
\hline Water, energie en nutsbedrijven & 17,7 & * \\
\hline Vrijwillige toetreders & 29,7 & \\
\hline Overig & 14,9 & * \\
\hline Bouw & 25,2 & \\
\hline Woningcorporaties & 23,7 & \\
\hline Totaal & 27,0 & 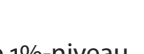 \\
\hline
\end{tabular}

Uit tabel 2.8 blijkt ook dat vooral werknemers in het hoge beroepsonderwijs, het defensie burgerpersoneel, wetenschappelijk onderwijs, onderzoek en wetenschapsbeleid en de universitaire medische centra zich door een doorwerkbonus gestimuleerd voelen om langer door te werken. Werknemers in de sector water, energie en nuts bedrijven zijn daarentegen het minst gevoelig voor een doorwerkbonus. 


\section{Anticiperen op langer doorwerken}

In dit hoofdstuk gaan wij in op de effecten van twee specifieke hervormingen van het pensioenstelsel op (I) de verwachtingen die werknemers van hun pensioenuitkering hebben en (2) hun verwachte pensioenleeftijd. Allereerst kijken we naar de effecten van de vermindering van de prepensioenrechten in 2006. Het betreft hier een update van de resultaten uit eerdere rapporten die zijn opgesteld op basis van de combinatie van administratieve data van het ABP met vijf enquêtes die zijn gehouden in de jaren 2007-20II onder een representatief panel van mannelijke fulltime werknemers bij de overheid en het onderwijs die zijn geboren in de jaren 1949 of $1950 .{ }^{17}$

Het vervallen van de prepensioenrechten (FPU) in de ABP-regeling, in combinatie met de invoering van het ABP Keuzepensioen kan vanuit onderzoeksperspectief worden gezien als een natuurlijk experiment, waarbij werknemers van vrijwel dezelfde leeftijd worden geconfronteerd met verschillende pensioenrechten. Hierdoor is het eenvoudig om het causale effect van financiële prikkels op het gedrag van werknemers te analyseren. De werknemers die geboren zijn in 1950 (en later) vallen namelijk sinds I januari 2006 onder ABP Keuzepensioen en zullen noodgedwongen langer moeten doorwerken indien zij bij vervroegde pensionering dezelfde pensioenuitkering wensen te ontvangen, terwijl de werknemers die geboren zijn voor 1950 (en op I januari 2006 minstens Io jaar werkzaam waren bij de overheid of in het onderwijs) nog gebruik kunnen maken van de oude FPU regeling. Verschillende kenmerken van het nieuwe pensioensysteem geven aan de werknemers die zijn geboren in 1950 extra prikkels tot langer werken:

I. Zij worden geconfronteerd met een daling in hun pensioenuitkering, tenzij ze later met pensioen gaan;

2. De hoogte van hun pensioenuitkering hangt in sterkere mate af van de leeftijd waarop zij met pensioen zullen gaan dan voor degenen die in 1949 zijn geboren. Vervroegd pensioneren voor de leeftijd van 65 jaar is duurder naarmate iemand die in 1950 is geboren eerder wil stoppen met werken.

17. A. de Grip, R. Montizaan (20II), Versoberde pensioenen en de werkinzet van oudere werknemers. Vervolgmeting (2010) VPL-onderzoek, ROA-R-20II/6, Universiteit Maastricht. A. de Grip, en R. Montizaan (2010), Langer doorwerken, werksituatie en productiviteit. Vervolgmeting (2009) VPL-onderzoek, ROA-R-20Io/8, Universiteit Maastricht. 
3. Werknemers worden de mogelijkheid geboden om tussen hun 6oste en hun 70 te met pensioen te gaan. In theorie is het dus mogelijk dat werknemers ook na hun 65ste blijven doorwerken.

Relevant is hierbij om op te merken dat de afschaffing van de FPU regeling dus zowel een inkomens- (daling van de uitkering bij vroegpensionering) als een prijseffect omvat (de hoogte van uitkering hangt sterker af van de pensioenleeftijd). De implicatie van deze hervorming van het pensioenstelsel is dat een werknemer met een 40-jarig dienstverband die geboren is in 1950 ongeveer I jaar en I maand langer moet werken om de oude norm van een vervangingsratio van $70 \%$ te bereiken (van het middelloon). Daarentegen kunnen werknemers die geboren zijn in 1949 (en eerder) en sinds I april 1997 continu hebben gewerkt bij een organisatie in de overheidssector of onderwijs, bij een 40-jarig dienstverband op een leeftijd van 62 jaar en 3 maanden tegen een vervangingsratio van $70 \%$ van hun middelloon met pensioen.

Ten tweede worden de effecten van de aanstaande verhoging van de AOW leeftijd, zoals deze is vastgelegd in het Pensioenakkoord, geanalyseerd op de verwachte pensioenleeftijd van de respondenten van de werknemersenquête die is verstuurd in 20 II naar een representatieve steekproef van alle werknemers van de overheid, onderwijs, de bouwsector en de woningcorporaties (in de leeftijd tussen 35 en 65 jaar).

Het pensioenakkoord houdt in dat de huidige pensioen- en AOW leeftijd van 65 jaar in 2020 wettelijk wordt verhoogd naar 66 jaar met waarschijnlijk in 2025 een verdere verhoging naar 67 jaar. Dit betekent dat wie in 1955 en later geboren is vanaf 2020 moet doorwerken tot 66 jaar. Eerder stoppen kan, maar dat kost jaarlijks wel 6,5\%. Doorwerken na 66 jaar wordt beloond met $6,5 \%$ per jaar. Voor degenen die geboren zijn in 1960 of later geldt dat zij waarschijnlijk moeten doorwerken tot 67 jaar. $^{18}$

\subsection{Impact afschaffing FPU op de verwachte pensioenuitkering}

Tabel 3.I laat het effect zien van de afschaffing van de FPU-regeling op de verwachte pensioenuitkering van werknemers die geboren zijn in 1949 of 1950 . Het betreft hier het antwoord op de vraag hoe hoog hun pensioenuitkering zou zijn (t.o.v. hun huidige salaris) als zij met pensioen zouden gaan op 62-jarige leeftijd. Uit de tabel valt af te lezen dat mensen die geboren zijn in 1950 een beduidend lagere uitkering verwachten

I8. Vanaf 2013 wordt de AOW jaarlijks opgehoogd met o,6 procent voor gehuwden. Dit wordt gedaan ter compensatie van dat mensen langer moeten werken. Daarnaast wordt om de vijf jaar bekeken of de pensioenleeftijd verder moet worden verhoogd vanwege de stijgende levensverwachting. Op grond van de huidige inzichten zal de AOW leeftijd in 2025 uitkomen op 67 jaar. Ook wordt er een mobiliteitsbonus geïntroduceerd die het aantrekkelijk moet houden voor werkgevers om oudere werknemers in dienst te houden. Wat betreft de aanvullende pensioenen impliceert het pensioenakkoord dat de pensioenuitkeringen in de toekomst in sterkere mate zullen afhangen van het succes van de beleggingsmix van de pensioenfondsen. 
indien zij op hun 62ste met pensioen zouden gaan, waarbij dit verschil ten opzichte van degenen die in 1949 zijn geboren in alle waarnemingsjaren statistisch significant is. Daarnaast blijkt dat het verschil in de verwachte pensioenuitkering tussen beide geboortejaren varieert over de tijd. In 2007 bedroeg het gemiddelde verschil 5,7\%punt. Dit verwachte verschil wijkt nauwelijks af van het feitelijke verschil in de pensioenrechten tussen de twee geboortejaren (6\%-punt). Daarentegen bedroeg het gemiddelde verschil in de verwachte pensioenhoogte tussen de beide leeftijdsjaren in 2008 slechts 3,7\%-punt. In de periode 2008-20II is het verschil tussen beide groepen echter weer toegenomen en vervolgens vrij stabiel gebleven op een realistisch niveau $(5,0 \%-$ punt in 2009, 5,8\%-punt in 2010 en $5,7 \%$-punt in $201 \mathrm{I}$ ).

Het effect van de financiële crisis die zich eind 2008 manifesteerde op de pensioenverwachtingen is substantieel. De tabel toont aan dat de verwachte pensioenuitkering voor beide geboortejaren substantieel gedaald is en dat deze dalende trend zich heeft doorgezet in 20II. Waarschijnlijk is dit een reactie is op de toegenomen onzekerheid over de pensioenuitkeringen. Zo heeft de financiële crisis en de toenemende levensverwachting geleid tot meer onzekerheid over de houdbaarheid van het huidige pensioenstelsel, zeker nu de kredietcrisis lijkt aan te houden door de slechte financiële positie van diverse Zuid-Europese landen. Bovendien heeft de financiële crisis geleid tot een daling van de dekkingsgraden van de pensioenfondsen in Nederland, met als gevolg dat pensioenen momenteel niet geïndexeerd worden, terwijl bovendien de kans bestaat dat pensioenfondsen extra moeten korten op de pensioenuitkeringen.

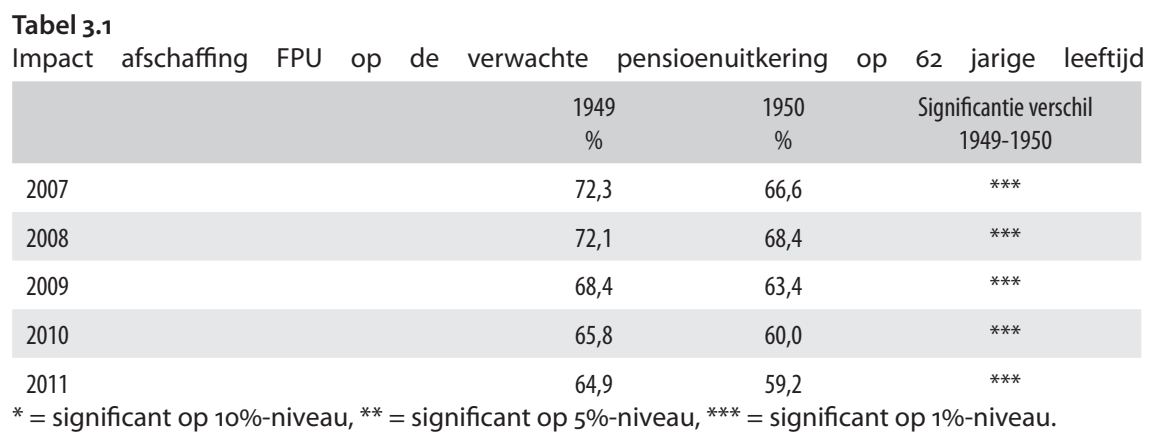

Tabel 3.2. laat de ontwikkeling zien van de verwachte pensioenuitkering als werknemers op 63- of 65-jarige leeftijd met pensioen zouden gaan. In overeenstemming met de feitelijke pensioenrechten, is de verwachte pensioenuitkering hoger naarmate de pensioenleeftijd hoger is. Zoals tabel 3.I liet zien denken werknemers die geboren zijn in 1950 een pensioenuitkering van 59,2\% te krijgen als zij met pensioen zouden gaan op 62-jarige leeftijd. Op 63- en 65-jarige leeftijd verwachten deze werknemers dat zij een pensioenuitkering zouden ontvangen van respectievelijk 66,I\% en $78,9 \%$. 
De mate waarin de verwachte pensioenuitkering stijgt met de pensioenleeftijd is ongeveer equivalent aan de feitelijke stijging van de pensioenuitkering. Dit duidt er op dat werknemers gemiddeld genomen goed op de hoogte zijn van de financiële prikkels die het pensioensysteem biedt om langer door te werken.

Tabel 3.2

Impact afschaffing FPU op de verwachte pensioenuitkering

$\begin{array}{cccc}1949 & 1950 & \text { Significantie verschil } \\ & \% & \% & 1949-1950\end{array}$

Stel u zou met 63 jaar met pensioen gaan

$\begin{array}{llll}2009 & 76,3 & 69,9 & * * * \\ 2010 & 74,2 & 66,7 & * * * \\ 2011 & 74,3 & 66,1 & * * *\end{array}$

Stel u zou met 65 jaar met pensioen gaan

$\begin{array}{lcc}2009 & 81,5 & 81,0 \\ 79,4 & 78,6 \\ 2010 & 78,7 & 78,9 \\ 2011 & * \\ * \text { = significant op 10\%-niveau, } & * * \text { = significant op 5\%-niveau, }{ }^{* * *}=\text { significant op 1\%-niveau. }\end{array}$

Dit blijkt ook uit het feit dat er geen verschil is in de verwachte uitkering op 65-jarige leeftijd voor beide groepen werknemers. Door de structuur van de financiële prikkels die het ABP Keuzepensioen biedt zullen werknemers die geboren zijn in 1949 en op 65-jarige leeftijd stoppen met werken geen andere uitkering moeten verwachten dan degenen die geboren zijn in 1950 en eveneens stoppen als zij 65 jaar zijn. Immers, de prikkels zijn zo ontworpen dat vervroegd pensioneren tot aan de leeftijd van 65 jaar duurder is voor degenen die geboren zijn in 1950.

\subsection{Impact afschaffing FPU op de verwachte pensioenleeftijd}

De vraag is vervolgens in hoeverre de werknemers die in 1950 zijn geboren hebben ingespeeld op de schok in hun pensioenrechten door het aanpassen van hun pensioneringsleeftijd. Tabel 3.3 laat de impact zien van de afschaffing van de FPU op de verwachte pensioenleeftijd. In 2007 verwachten beide groepen met pensioen te gaan op een leeftijd waarop zij gemiddeld genomen een vervangingsratio van $70 \%$ van hun bruto middelloon kunnen realiseren.

De tabel laat echter ook zien dat de financiële prikkels op de langere termijn minder groot zijn dan direct na de herziening van het pensioenstelsel. Zowel de werknemers die geboren zijn in 1949 als degenen die geboren zijn in 1950 hebben in 2008 de verwachte pensioenleeftijd naar beneden bijgesteld. Het verschil in de pensioenleeftijd tussen de mensen die geboren zijn in 1949 of 1950 bedroeg in dat jaar nog maar drie maanden. Vanaf 2009 is het verschil tussen beide groepen weer licht gestegen naar iets 
meer dan 5 maanden, maar dit blijft aanzienlijk minder dan het verschil direct na de herziening van het pensioenstelsel. Vanaf 2009 blijkt er overigens bij zowel degenen die in 1949 geboren zijn als het 1950-cohort dat de verwachte pensioenleeftijd weer stijgt, waarschijnlijk doordat de pensioenen niet worden geïndexeerd door de lage dekkingsgraden als gevolg van de financiële crisis. Het lijkt erop dat de kredietcrisis ertoe heeft geleid dat mensen ruim een jaar langer denken te moeten doorwerken. Ook valt te zien dat de verwachte pensioenleeftijd in $201 \mathrm{I}$ nog in beperkte mate verder is toegenomen. ${ }^{19}$

Tabel 3.3

Impact afschaffing FPU op de verwachte pensioenleeftijd

\begin{tabular}{|c|c|c|c|}
\hline & $\begin{array}{c}1949 \\
\%\end{array}$ & $\begin{array}{c}1950 \\
\%\end{array}$ & $\begin{array}{c}\text { Significantie verschil } \\
\quad 1949-1950\end{array}$ \\
\hline 2007 & 62,6 & 63,5 & *** \\
\hline 2008 & 61,8 & 62,1 & $* * *$ \\
\hline 2009 & 63,1 & 63,4 & $* * *$ \\
\hline 2010 & 63,4 & 63,9 & $* * *$ \\
\hline 2011 & 63,7 & 64,2 & $* * *$ \\
\hline
\end{tabular}

\subsection{Werkgever biedt alternatieve mogelijkheden voor vervroegde uittrede}

Tabel 3.4 laat zien dat de werknemers die geboren zijn in 1950 ook significant minder vaak alternatieve mogelijkheden krijgen aangeboden van hun werkgever om vervroegd uit te treden. Dit valt waar te nemen voor de hele periode 2007-20II. Na het uitbreken van de crisis in 2008 is het percentage werknemers dat aangeeft dat hun werkgever alternatieve mogelijkheden voor vervroegde uittrede aanbiedt, structureel toegenomen. Dit geldt specifiek voor degenen die geboren zijn in 1949 en dus eerder met pensioen kunnen. Het percentage werknemers met alternatieve mogelijkheden voor vervroegde uittrede is in deze groep gestegen met ruim 13,5\%-punt, tegenover slechts 5,0\%-punt voor het 1950 -cohort. Dit duidt erop dat een deel van de werkgevers in de overheids- en onderwijssector er kennelijk de voorkeur aan geeft hun personeelsbestand te verkleinen door werknemers met hogere pensioenrechten te bewegen tot vervroegde uittrede.

I9. De stijging van de verwachte pensioenleeftijd als gevolg van de financiële crisis kan verklaard worden door het achterblijven van de indexering van de pensioenen en de recentelijk aangekondigde versoberingen van de pensioenen als gevolg van dat de dekkingsgraden onvoldoende zijn herstelt. 
Tabel 3.4

Impact afschaffing FPU op aanbod van alternatieve mogelijkheden voor vervroegde uittrede

\begin{tabular}{lccc|} 
& 1949 & 1950 & Significantie verschil \\
& $\%$ & $\%$ & $* 49-1950$ \\
2007 & 8,7 & 7,4 & $* *$ \\
2008 & 8,7 & 6,8 & $* * *$ \\
\hline 2009 & 12,9 & 9,9 & $* * *$ \\
\hline 2010 & 21,6 & 14,9 & $* * *$ \\
\hline 2011 & 22,1 & 12,4 & $* *$ \\
\hline
\end{tabular}

$*$ significant op $10 \%$-niveau, ${ }^{* *}=$ significant op $5 \%$-niveau, ${ }^{* * *}=$ significant op $1 \%$-niveau.

Van de werknemers die geantwoord hebben dat hun werkgever alternatieve mogelijkheden aanbiedt voor vervroegde uittrede, geeft $67 \%$ in een open vraag aan welke mogelijkheden hen worden aangeboden (tabel 3.5). Het vaakst wordt genoemd dat de werkgever hun oudere werknemers dringend verzoekt om met FPU te gaan, een extra premie of een aanvulling biedt als zij met FPU gaan (ruim 27,2\% noemt deze optie). Ook de mogelijkheid tot deeltijdpensioneren wordt relatief vaak genoemd (I7,7\%). Daarbij gaat het vaak om de mogelijkheid in deeltijd te gaan werken met behoud van het fulltime salaris en om een aanvullende pensioenpremie bij deeltijdwerk. Daarnaast worden leeftijdsregelingen $(5,6 \%)$ en een stimulans om te participeren in de levensloopregeling $(5,3 \%)$ genoemd. De overige genoemde regelingen hebben meestal betrekking op de persoonlijke situatie van een werknemer, of zijn gerelateerd aan herstructureringen van de werkplek.

Tabel 3.5

Alternatieve mogelijkheden voor vervroegde uittrede (percentages)

FPU (dringend verzoek van werkgever om met FPU te gaan, premie om met FPU te gaan, aanvulling FPU regeling)

Deeltijdpensionering (mogelijkheid tot deeltijdpensionering/werk, deeltijdpensionering met behoud fulltime salaris, deeltijdwerk met correctie overschot vakantie uren, aanvulling pensioenpremie bij deeltijdwerk)

Leeftijdsregeling (werkgever hanteert regeling die eerder uitreden mogelijk maakt, aanvulling van bestaande pensioenregelingen)

Levensloopregeling (werkgever stimuleert levensloopregeling)

\subsection{Verhoging AOW leeftijd en pensioenverwachtingen}

In het kader van het onlangs afgesloten pensioenakkoord is het relevant om te kijken in hoeverre werkenden op de hoogte zijn van de aanstaande verhogingen van de AOW leeftijd. Als het gaat om het inschatten van de mogelijke gedragseffecten van de verhoging van de AOW leeftijd is het goed te beseffen dat het hierbij overigens vooral een inkomenseffect teweegbrengt: wie geboren is in 1955 of later moet I jaar langer doorwerken om hetzelfde vervangingsinkomen te krijgen. ${ }^{20}$ Echter, de verhoging van de

20. De verhoging van de pensioenleeftijd kan echter ook leiden tot een intertemporele substitutie van vrije tijd in verschillende perioden van de levenscyclus. 
AOW leeftijd gaat ook gepaard met de introductie van een prijs van vrije tijd prikkel: wie na zijn 66e (67e vanaf 2025) doorwerkt krijgt 6,5\% meer AOW. Dat laatste betekent overigens dat de pensioenleeftijd meer flexibel wordt: gegeven de prikkelstructuur kan men zelf kiezen wanneer men stopt met werken.

Kolom I van tabel 3.6 laat zien dat werknemers die geboren zijn in de periode I955I960 inderdaad significant later met pensioen denken te gaan. Gemiddeld genomen denkt deze groep vier maanden langer te moeten doorwerken dan degenen die geboren zijn in andere cohorten. Uit kolom 2 blijkt dat degenen die geboren zijn in I960 of later niet significant later denken uit te reden. Hiervoor bestaan twee mogelijke verklaringen: Allereerst kan dit worden toegeschreven aan het betrekkelijk lage aantal respondenten dat na 1959 is geboren. Daarnaast bleek al in hoofdstuk 2 dat de spreiding in de verwachte pensioenleeftijd bij jongere werknemers veel groter is dan bij oudere werknemers. De langere periode tot aan hun pensioen zorgt ervoor dat de pensioenleeftijd met meer onzekerheden is omgeven. Bovendien zijn jongere medewerkers nog minder geïnteresseerd in hun pensionering, waardoor zij ook mogelijk ook minder goed geïnformeerd zijn over de implicaties van de aankomende veranderingen in het pensioenstelsel. Het is derhalve ook niet verrassend dat het effect van de veranderde pensioenrechten op de verwachte pensioenleeftijd voor degenen die geboren zijn in 1960 of later relatief klein is. Daarentegen laten kolommen 3 en 4 zien dat het percentage werknemers dat verwacht op 66 en 67 jaar met pensioen te gaan respectievelijk bijna $20 \%$ en $11 \%$ hoger ligt voor degenen die geboren zijn in de periode 1955 -I959 en 1960-1975.

Tabel 3.6

Verhoging AOW leeftijd en pensioenverwachtingen

\begin{tabular}{|c|c|c|c|c|}
\hline & $\begin{array}{c}\text { (1) } \\
\text { Verwachte } \\
\text { pensioen- } \\
\text { leeftijd }\end{array}$ & $\begin{array}{l}\quad(2) \\
\text { Verwachte } \\
\text { pensioen- } \\
\text { leeftijd }\end{array}$ & $\begin{array}{c}\text { (3) } \\
\text { Percentage } \\
\text { werknemers dat } \\
\text { verwacht op } 66 \\
\text { jaar met pensioen } \\
\text { te gaan }\end{array}$ & $\begin{array}{c}\text { (4) } \\
\text { Percentage } \\
\text { werknemers dat } \\
\text { verwacht op } 67 \\
\text { jaar met pensioen } \\
\text { te gaan }\end{array}$ \\
\hline Verhoging tot 66 jaar (geboortejaar 1955-1959) & $0,357^{* *}$ & & $0,188^{* * *}$ & \\
\hline Verhoging tot 67 jaar (geboortejaar 1960-1975) & & 0,443 & & $0,107^{* * *}$ \\
\hline Leeftijd & $0,076^{* *}$ & 0,038 & 0,003 & $-0,002$ \\
\hline Aantal contributiejaren & $-0,033^{* * *}$ & $-0,035^{* * *}$ & $-0,000$ & $-0,003^{* *}$ \\
\hline Deeltijdfactor & $2,314^{* * *}$ & $3,145^{* * *}$ & $0,132^{* * *}$ & $0,248^{* * *}$ \\
\hline Geslacht & $0,519^{* * *}$ & $0,384^{* *}$ & 0,006 & 0,014 \\
\hline Inkomen & $-0,578^{* * *}$ & $-1,047^{* * *}$ & $-0,047^{* *}$ & $-0,079^{*}$ \\
\hline Constante & $62,693^{* * *}$ & $67,521^{* * *}$ & 0,207 & 0,818 \\
\hline $\mathrm{N}$ & 2.588 & 1.437 & 2.588 & 1.437 \\
\hline
\end{tabular}


Om een beter beeld te krijgen van de effecten van de verhoging van de AOW leeftijd op de verwachte pensioenleeftijd geeft figuur 3.I grafisch weer hoe hoog het percentage werknemers is dat met pensioen verwacht te gaan op 65-, 66- en 67-jarige leeftijd. Op basis van het pensioenakkoord kan verwacht worden dat het percentage werknemers dat met pensioen denkt te gaan op 65-jarige leeftijd lager zou zijn voor degenen die geboren zijn in 1955 of later, het percentage werknemers dat met pensioen denkt te gaan op 66-jarige leeftijd uitsluitend hoger moet liggen voor degenen die geboren zijn in de periode 1955-1959, en dat het percentage dat met pensioen denkt te gaan op 67 -jarige leeftijd hoger ligt voor degenen die geboren zijn in 1960 of later.

De figuur laat zien dat de afwijkingen in de percentages overeenkomen met onze verwachtingen. Er is een duidelijke daling zichtbaar in het percentage werknemers dat met 65 jaar met pensioen denkt te gaan bij degenen die geboren zijn tussen 1955 en I960. Voor degenen die geboren zijn in 1954 was dit percentage $45,6 \%$, terwijl voor degenen die geboren zijn in 1955 dit maar $26,2 \%$ is. Daarentegen is het percentage werknemers dat met pensioen denkt te gaan op 66-jarige leeftijd substantieel hoger voor het 1955 -1959 cohort (stijging van $13,4 \%$ in 1954 naar $20,0 \%$ in 1955 ).

Figuur 3.1

Verhoging AOW leeftijd en pensioenverwachtingen

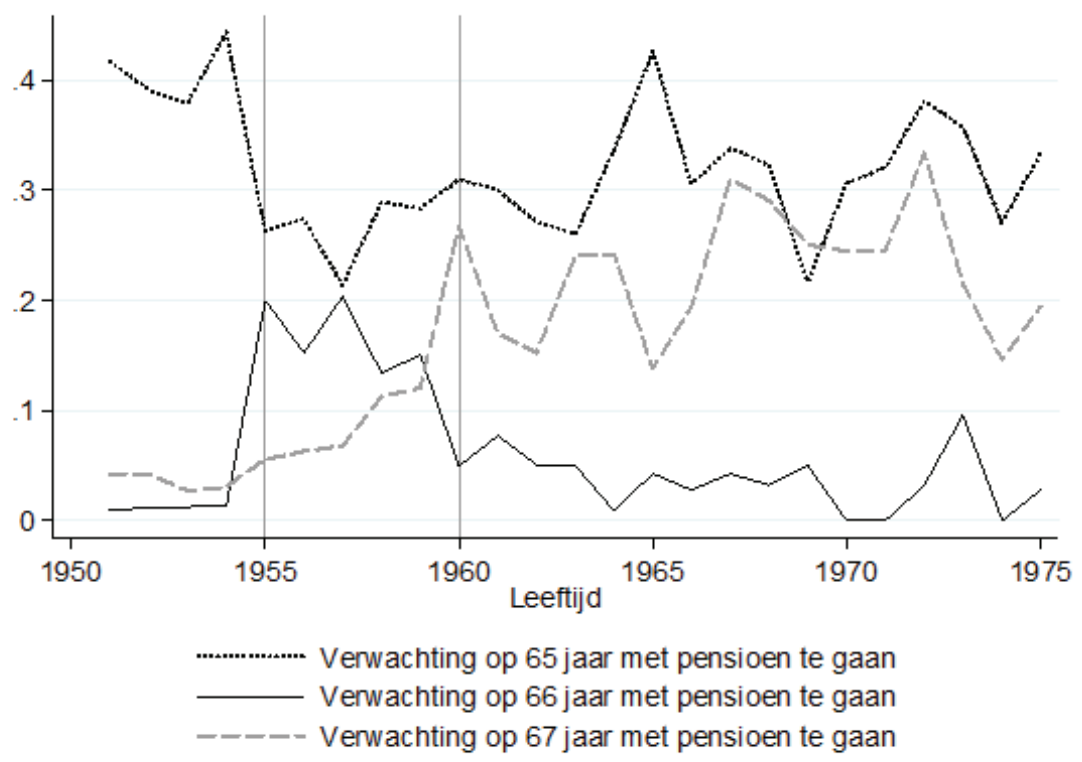

Ook de effecten van het verschuiven van de AOW leeftijd naar 67 jaar zijn enigszins zichtbaar, hoewel deze effecten duidelijk minder sterk zijn dan die van de versobering naar 66 jaar. Het percentage werknemers dat denkt door te werken tot 66 jaar is in het cohort dat in 1960 of later is geboren substantieel lager (daling van $\mathrm{I6,I} \%$ in 1959 
naar $4,9 \%$ in 1960). Daarentegen is er een kleine stijging zichtbaar in het percentage werknemers dat denkt door te werken tot 67 jaar. Verder valt af te lezen dat het percentage sterk schommelt met het geboortejaar voor degenen die geboren zijn in 1960 of later. Deze uitschieters kunnen worden verklaard door het relatief kleine aantal respondenten in dit cohort. 



\section{Werknemersinzet en percepties van het gevoerde personeelsbeleid}

Vanaf 2006 is de feitelijke pensioenleeftijd gestegen als gevolg van de invoering van wetswijzigingen en regelgeving gericht op de inperking van vervroegde pensioenregelingen. Het aantal werknemers dat vóór het 6oste levensjaar met pensioen ging, is daardoor in 2007 sterk afgenomen. In 2009 en 2010 liep de pensioenleeftijd nog verder op. ${ }^{21}$ Verwacht kan worden dat deze trend zich zal doorzetten als gevolg van de afschaffing van de FPU, de dalende dekkingsgraden van de pensioenfondsen en de geplande verhoging van de ingangsleeftijd van de AOW. Werknemers zullen zich moeten instellen op een verlenging van hun arbeidsloopbaan met op zijn minst een aantal jaren en moeten zich afvragen hoe ze dat op een plezierige, gezonde en productieve wijze kunnen doen bij hun huidige werkgever, of elders.

Werkgevers zullen zich eveneens moeten beraden op de vraag hoe zij uiteenlopende groepen werknemers tot op hogere leeftijd gemotiveerd, gezond en productief aan het werk kunnen blijven houden, dan wel naar ander werk kunnen toeleiden. Een belangrijke vraag hierbij is natuurlijk of oudere werknemers minder gemotiveerd voor hun werk zijn en in hoeverre hun productiviteit-beloningsverhouding ongunstiger is dan bij jongere medewerkers. Vanuit dit perspectief is het ook belangrijk om een goed beeld te krijgen van de HR instrumenten die werkgevers inzetten om de inzetbaarheid van hun oudere medewerkers op peil te houden. Daarbij richten we ons in dit hoofdstuk op het beeld dat werknemers hebben van de HR instrumenten die hun werkgever momenteel inzetten om hun functioneren en loopbaanontwikkeling te bevorderen, en in hoeverre deze percepties van invloed zijn op hun werkinzet en pensioenverwachtingen.

\subsection{Werknemersinzet}

Neemt de inzetbaarheid van medewerkers af met hun leeftijd? Binnen de literatuur bestaat hierop geen eenduidig antwoord. Enerzijds is bekend dat oudere werknemers veel kennis en ervaring met zich mee brengen die nuttig is voor werkgevers,

2I. CBS, (20II), Pensioenleeftijd werknemers weer hoger, Web Magazine, 03-06-20II. 
en dat zij worden geacht loyaler en betrouwbaarder te zijn. ${ }^{22}$ Anderzijds heerst het beeld dat ouderen minder goed in staat zijn om een bijdrage te leveren aan nieuwe ontwikkelingen, en dat de kennis van ouderen meer onderhevig zou zijn aan erosie dan de kennis van jongeren en dat oudere werknemers minder gemotiveerd zijn. ${ }^{23}$ Psychologen maken een onderscheid tussen aan de ene kant fluid intelligence dat bijvoorbeeld betrekking heeft op het goed kunnen onthouden en het oplossen van nieuwe problemen en aan de andere kant crystallized intelligence dat betrekking heeft op de kennis en vaardigheden die iemand opdoet in het onderwijs of door werkervaring. Uit verschillende studies blijkt dat fluid intelligence afneemt naarmate iemand ouder wordt, terwijl de aan werkervaring gerelateerde crystallized intelligence vaak groter is bij oudere werknemers. ${ }^{24}$

Onze dataset makkt het mogelijk om de werkmotivatie van oudere werknemers te vergelijken met die van jongere werknemers. Iemands werkmotivatie wordt daarbij gemeten aan de hand van twee indicatoren: het percentage onbetaalde overuren en de bevlogenheid van werknemers. Tabel 4.I laat zien dat het percentage werknemers dat overuren maakt in de leeftijdsgroep van 35 tot en met 44 jaar 54,I\% bedraagt, terwijl dit percentage in de leeftijdsgroep van 55 tot en met 64 jaar beduidend lager is: $47,0 \%$. Het is echter, opvallend dat het percentage werknemers met onbetaalde overuren tussen de verschillende leeftijdsgroepen niet afwijkt. Dit duidt erop dat de motivatie van oudere werknemers voor hun baan niet per definitie lager ligt. Het lijkt er op dat het verschil in het percentage medewerkers dat overuren verricht vooral wordt veroorzaakt doordat jongere cohorten gevoeliger zijn voor financiële prikkels.

\section{Tabel 4.1}

Percentage werknemers dat overuren maakt naar leeftijdsgroep

\begin{tabular}{lccc} 
& $35-44$ & $45-54$ & $55-64$ \\
& $\%$ & $\%$ & $\%$ \\
\hline Overuren & 54,1 & 53,1 & 47,0 \\
Overuren onbetaald & 38,3 & 38,7 & 38,6 \\
\hline Overuren betaald & 15,8 & 14,4 & 8,4
\end{tabular}

Figuur 4.I laat zien dat vooral jongere werknemers in de sector woningcorporaties meer overuren maken. Werknemers in de bouw en bij de overheid en onderwijs maken relatief minder (geregistreerde) overuren. In de sector overheid en onderwijs is het verschil in het percentage jongeren en ouderen dat overwerkt veel minder groot dan in de bouw en woningcorporaties. Een leeftijdsverschil van één jaar zorgt voor

22. Zie P. Visser, K. Henkens en J. Schippers (2003), Beeldvorming en stereotypering van oudere werknemers in organisaties. Gedrag \& Organisatie, 16, 2-22.

23. Zie J.G. Boerlijst en B.I.J.M. van der Heijden (2003), Leeftijdsdiversiteit in arbeidsorganisaties, in: J.J.F. Schroots (red.), Handboek psychologie van de volwassen ontwikkeling \& veroudering, Van Gorcum, Assen.

24. Zie bv. R. J. Willis (2007), "Cognitive Economics and Human Capital," Presidential Address Society of Labor Economists, Chicago, May 4-5. 
een $0,3 \%$ lagere kans om overuren te maken, tegenover een I,4\% lagere kans voor werknemers in de bouw en woningcorporaties.

\section{Figuur 4.1}

Percentage werknemers dat overuren maakt

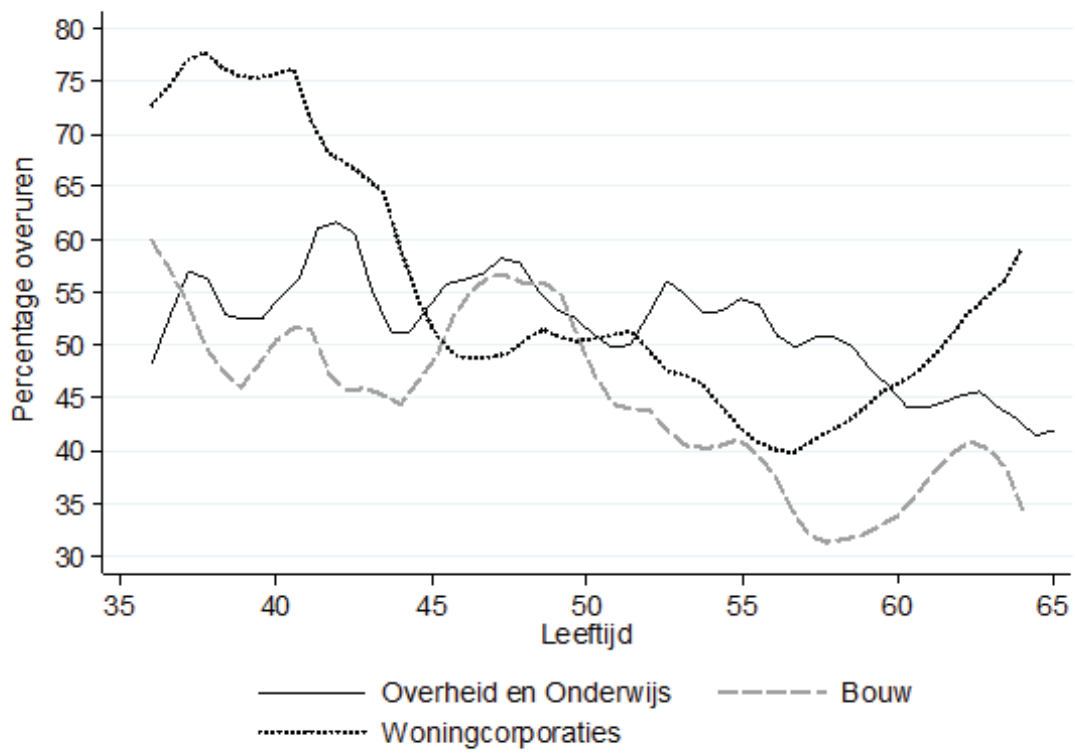

Figuur 4.2 laat zien hoe bevlogen werknemers zijn. Het begrip bevlogenheid ('engagement') komt uit de arbeidspsychologie en heeft betrekking op een positieve gevoelsmatige toestand die werknemers motiveert om hun werkdoelen beter en sneller te bereiken en daarmee het belang te dienen van de organisatie waarin zij werken. Bevlogenheid wordt ook wel beschouwd als de tegenhanger van burn-out en gedefinieerd als 'een positieve, werkgerelateerde psychische toestand die gekarakteriseerd wordt door vitaliteit, toewijding en absorptie. ${ }^{25}$ Vitaliteit wordt daarbij gekenmerkt door een hoog niveau van energie, mentale veerkracht tijdens werk, inspanningsbereidheid en doorzettingsvermogen. Toewijding wordt gekenmerkt door een sterke betrokkenheid bij het werk, enthousiasme, trots en een gevoel van inspiratie en uitdaging. Als laatste wordt absorptie gekenschetst door het moeilijk los kunnen laten van het werk en het volledig er in opgaan waardoor de tijd voorbij vliegt. Deze drie aspecten van bevlogenheid liggen ten grondslag aan de korte versie van de Utrecht Work Engagement Schaal (UWES) die uitvoerig is getest op betrouwbaarheid en validiteit en is toegevoegd aan de vragenlijst. De schaal bestaat uit negen vragen:

25. Zie W.B. Schaufeli, M. Salanova, V. Gonzélez-Romá en A.B. Bakker (2002), The measurement of Engagement and burnout: A confirmative analytic approach, Journal of Happiness Studies, 3, 7I-92. 
Hoe vaak hebt u de volgende gevoelens over uw werk?

- $\quad$ Als ik werk bruis ik van energie

- Ik voel mij sterk en fit wanneer ik aan het werk ben

- Ik ben enthousiast over de inhoud van mijn werk

- Mijn werk inspireert mij

- Als iks 'ochtends opsta heb ik zin om naar mijn werk te gaan

- Wanneer ik intensief aan het werk ben, voel ik mij gelukkig

- Ik ben er trots op dat ik dit werk doe

- Ik ga helemaal op in mijn werk

- Ik laat me meeslepen door het werk waar ik mee bezig ben

De respondenten dienden vervolgens antwoord te geven op een 7-puntsschaal die loopt van I (nooit) tot 7 (altijd).

\section{Figuur 4.2}

Bevlogenheid voor het werk

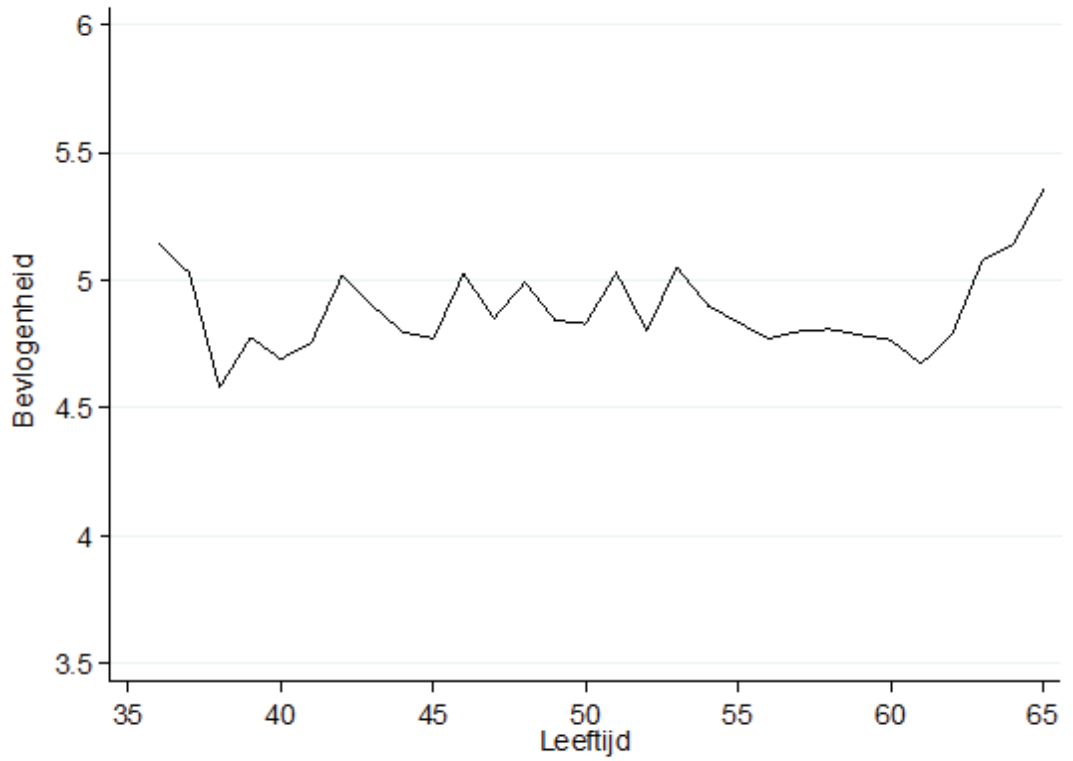

Duidelijk blijkt uit de figuur dat er tussen jongere en oudere werknemers geen significant verschil bestaat in hun bevlogenheid voor het werk. De stijging vanaf 60 wordt veroorzaakt doordat de meest gemotiveerde werknemers later met pensioen gaan. Als we deze leeftijdsgroep buiten onze analyses laten, dan vinden wij nog steeds dat de bevlogenheid voor het werk van jongere en oudere werknemers niet verschilt. Dit 
versterkt het beeld dat werknemers niet minder gemotiveerd raken voor hun baan als zij ouder worden. ${ }^{26}$

Een andere belangrijke vraag is of oudere werknemers ongezonder zijn dan jongere werknemers. Veelal wordt verondersteld dat de gezondheid afneemt met het ouder worden. Het is bekend dat mensen fysiek achteruit gaan naarmate men ouder wordt en dat de kans op ziekten zoals kanker en hart- en vaatziekten toeneemt naarmate iemand ouder wordt. ${ }^{27}$

Tabel 4.2 laat zien dat oudere werknemers inderdaad minder vaak aangeven in goede gezondheid te zijn. Terwijl in de leeftijdsgroep van $35-44$ jaar $83,6 \%$ van de werkenden aangeeft een goede gezondheid te hebben, geeft $75,3 \%$ van de werkenden in de leeftijd van $55-65$ jaar aan dat dit het geval is. Interessant is echter dat dit verschil betrekkelijk klein is. Het overgrote deel van ouderen ondervindt geen gezondheidsproblemen. De vraag is derhalve in hoeverre de gezondheid voor de meeste werknemers een belemmering zal vormen om door te kunnen werken.

Tabel 4.2

Gezondheid werknemers

\begin{tabular}{lccc} 
& $35-44$ & $45-54$ & $55-65$ \\
\hline Werknemer beoordeelt zijn gezondheid als goed of zeer goed & $83,6 \%$ & $81,4 \%$ & $75,3 \%$ \\
\hline Percentage werknemers dat zich niet ziek meldt & $36,7 \%$ & $45,1 \%$ & $46,0 \%$ \\
\hline Aantal ziektedagen als men zich ziek heeft gemeld & 8,6 & 10,9 & 15,4
\end{tabular}

Het is opmerkelijk dat het percentage oudere werknemers dat zich ziek meldt maar liefst 13,3\%-punt lager ligt dan bij jongere medewerkers. Daarentegen duurt het verzuim langer als oudere werknemers zich ziek melden. Werknemers in de leeftijd van 35-44 jaar zijn gemiddeld genomen 8,6 werkdagen ziek, terwijl de 55 tot 65 jarigen gemiddeld 15,4 dagen opnemen. Het verschil in de mediaan is echter een stuk kleiner (3 versus 5 dagen). Dit duidt erop dat het verschil in het aantal opgenomen ziektedagen vooral wordt veroorzaakt door een zeer kleine groep oudere werknemers met gezondheidsproblemen die tot langdurig ziekteverzuim leiden. Voor het overgrote deel van de oudere werknemers geldt echter dat zij gezond zijn.

26. Regressieanalyses op de relatie tussen bevlogenheid en leeftijd tonen eveneens aan dat de bevlogenheid van werknemers niet afhangt van leeftijd.

27. Zie M. Peeters, A. Nauta, J. de Jonge, R. Schalk (2005), 'De toekomst van oudere werknemers: de revival van een 'oud' thema in de arbeids- en organisatiepsychologie', Gedrag \& Organisatie 2005-18, nr. 6, 297-308. 
Figuur 4.3

Ziektedagen

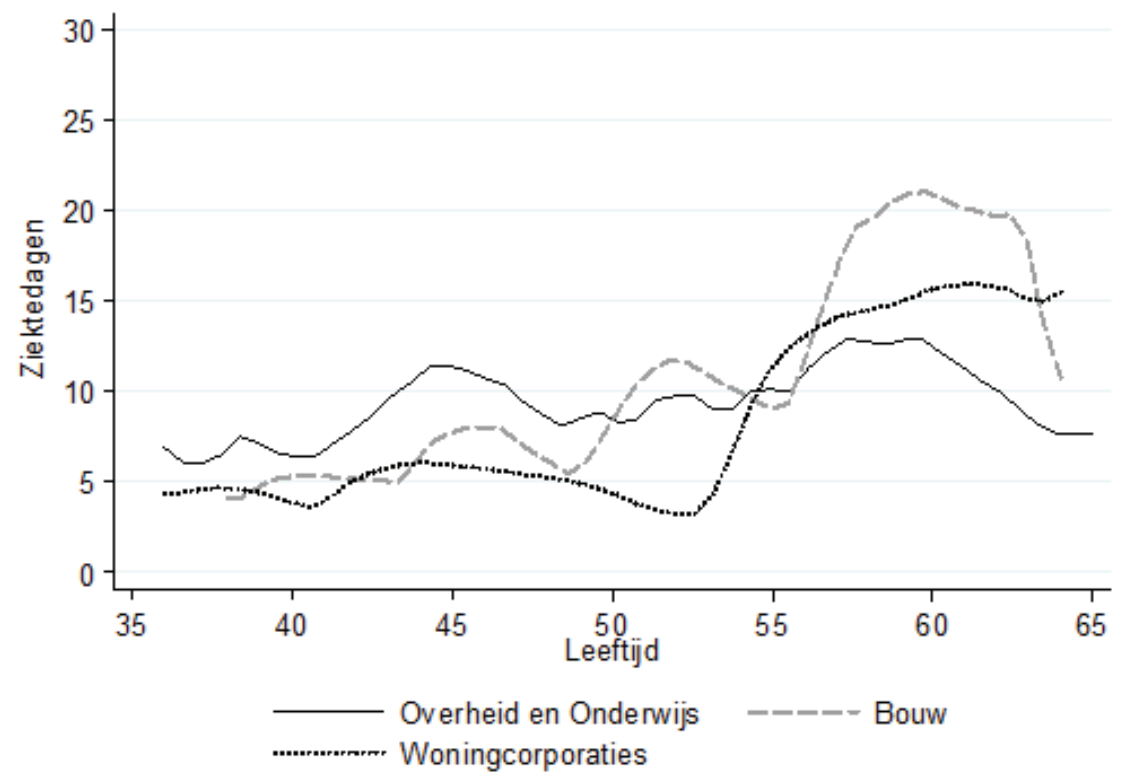

Doordat ouderen minder snel ziekteverlof opnemen, bestaat zelfs de mogelijkheid dat de kosten door gezondheidsproblemen voor de werkgever van een grote groep oudere werknemers lager zullen zijn dan van jongere werknemers. Deze analyses geven aan dat de gezondheid van de meeste oudere werknemers geen barrière zou moeten vormen voor werkgevers om te investeren in het menselijk kapitaal van oudere medewerkers, om daarmee hun arbeidsloopbaan te kunnen verlengen. Dit geldt specifiek voor de sector overheid en onderwijs.

Figuur 4.3 toont aan dat het aantal ziektedagen in deze sector nauwelijks stijgt met het oplopen van de leeftijd. Daarentegen vinden we in de bouw wel een sterk significant effect van leeftijd op het aantal ziektedagen. Vooral vanaf een leeftijd van 55 jaar valt er een duidelijke stijging waar te nemen in het aantal ziektedagen, waarschijnlijk als gevolg van het feit dat werknemers in deze sector vanaf deze leeftijd moeite krijgen met de fysiek zware belasting van hun beroep.

\subsection{Personeelsbeleid: aandacht voor functioneren en loopbaanontwikkeling}

Om een goed beeld te krijgen van het personeelsbeleid van werkgevers is het relevant om een overzicht te krijgen van de HR instrumenten die volgens werknemers door hun werkgever op dit ogenblik worden ingezet ten bate van hun functioneren en loopbaanontwikkeling. 
De figuren $4.4-4.6$ geven een overzicht van de mate waarin HR instrumenten worden ingezet om het functioneren van werknemers te bevorderen. Uit de figuren blijkt dat veruit de meeste ingezette HR instrumenten gericht zijn op ontwikkeling en scholing. $76,5 \%$ en $45,2 \%$ van de werknemers geeft aan dat zij in het afgelopen jaar een functionerings- of beoordelingsgesprek hebben gehad. In totaal heeft 59,3\% het afgelopen jaar een cursus of training gevolgd, waarbij 3I,I\% aangeeft dat zij bij- of nascholing hebben gehad, die specifiek op hun functioneren en/of loopbaanontwikkeling was gericht. Het opstellen van een persoonlijk ontwikkelingsplan $(2 \mathrm{I}, 6 \%)$, persoonlijk opleidingsplan $(\mathrm{I} 3,4 \%)$ of loopbaanplan $(3,9 \%)$ en coaching $(\mathrm{I} 2,9 \%)$ worden daarentegen slechts door een kleine groep genoemd.

Figuur 4.5 laat zien dat maar een kleine groep werknemers aangeeft dat HR instrumenten worden ingezet op het gebied van beloning en detachering. Het vaakst worden prestatiebeloning $(8,9 \%)$ en bonussen ingezet $(7,1 \%)$. Detachering en demotie zijn vrij impopulaire maatregelen. Slechts I,2\% van alle werknemers heeft in het afgelopen jaar te maken gehad met demotie.

\section{Figuur 4.4}

Op welke wijze heeft de organisatie waar $u$ werkt in het afgelopen jaar aandacht besteed aan uw functioneren en / of loopbaanontwikkeling: Ontwikkeling en scholing

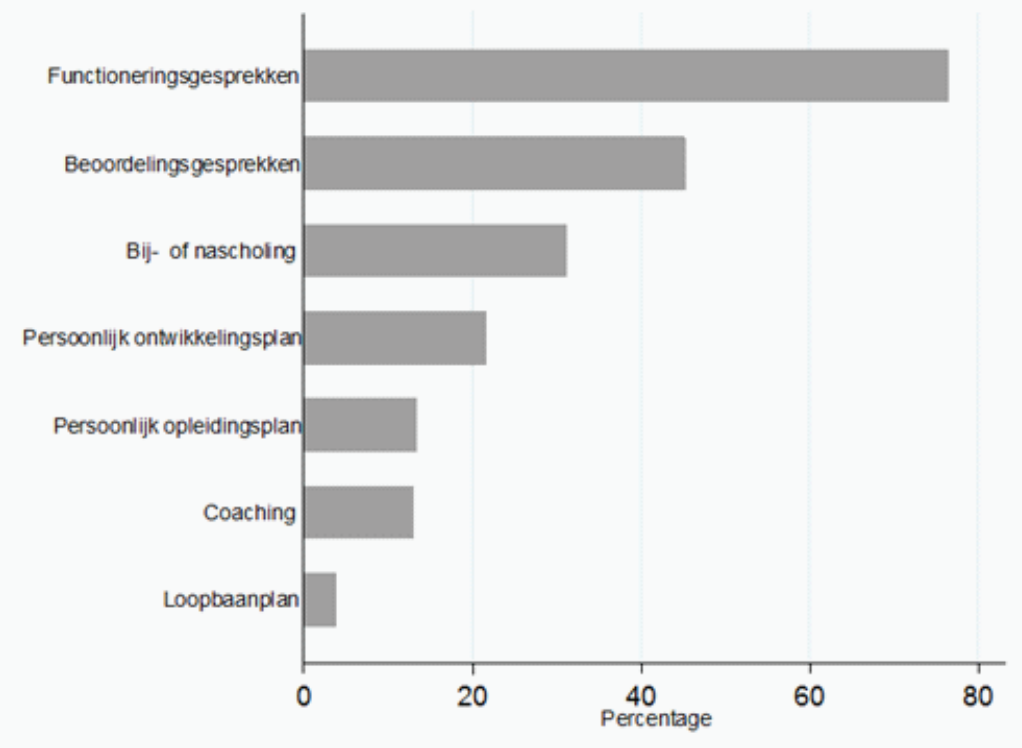




\section{Figuur 4.5}

Op welke wijze heeft uw organisatie waar u werkt in het afgelopen jaar aandacht besteed aan uw functioneren en / of loopbaanontwikkeling: Beloning en detachering

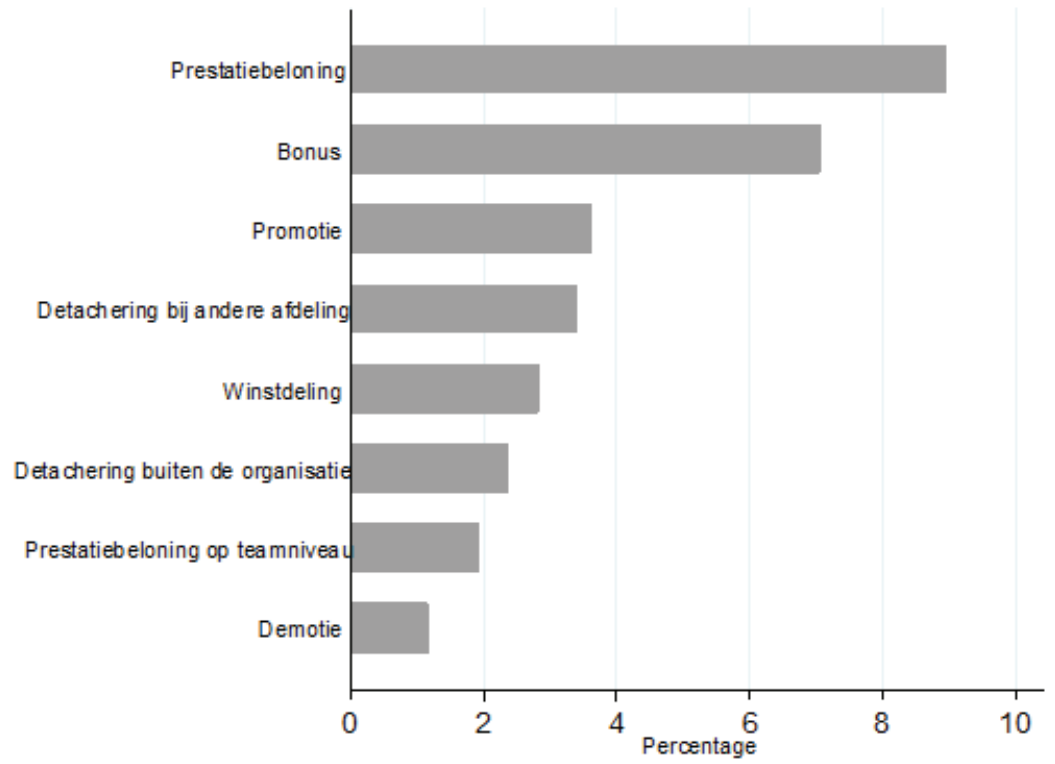

Figuur 4.6 laat zien dat er ook weinig werknemers in het kader van hun functioneren en / of loopbaanontwikkeling te maken hebben gekregen met een aanpassing van hun werkplek of werkdruk. Voor ruim I2,2\% van de werknemers is de werkplek verbeterd, terwijl II,O\% te maken kreeg met taakverbreding. Interessant is dat taak- en functieroulatie $(2,4 \%$ en $2,2 \%)$ maar in zeer beperkte mate worden toegepast. Opvallend is verder dat er geen HR instrumenten worden ingezet die gericht zijn op het verminderen van het aantal overuren en het vrijstellen van ongunstige werktijden, ondanks het feit dat ongeveer de helft van alle werknemers overuren maakt.

Figuur 4.7 laat zien op basis van stellingen hoe tevreden werknemers zijn over het personeelsbeleid van de organisatie waarin zij werkzaam zijn. Uit de figuur valt op te maken dat de meeste werknemers vrij negatief oordelen over het personeelsbeleid van hun werkgever. Slechts 32,0\% heeft hierover een positief oordeel. Daarentegen vindt $28,6 \%$ dat het personeelsbeleid van hun werkgever niet voldoet en $39,4 \%$ is neutraal. Op de bepaalde facetten van het personeelsbeleid scoort het personeelsbeleid echter beter. Ruim 73,2\% van alle werknemers geeft aan dat hun werkgever de mogelijkheid biedt om in deeltijd te gaan werken. Eveneens geeft $57,8 \%$ en $56,2 \%$ aan dat hun werkgever zorg en ondersteuning biedt indien dat nodig zou zijn en dat hun leidinggevende voldoende waardering voor hen heeft. 


\section{Figuur 4.6}

Op welke wijze heeft uw organisatie waar u werkt in het afgelopen jaar aandacht besteed aan uw functioneren en / of loopbaanontwikkeling: Werkplek en werkdruk

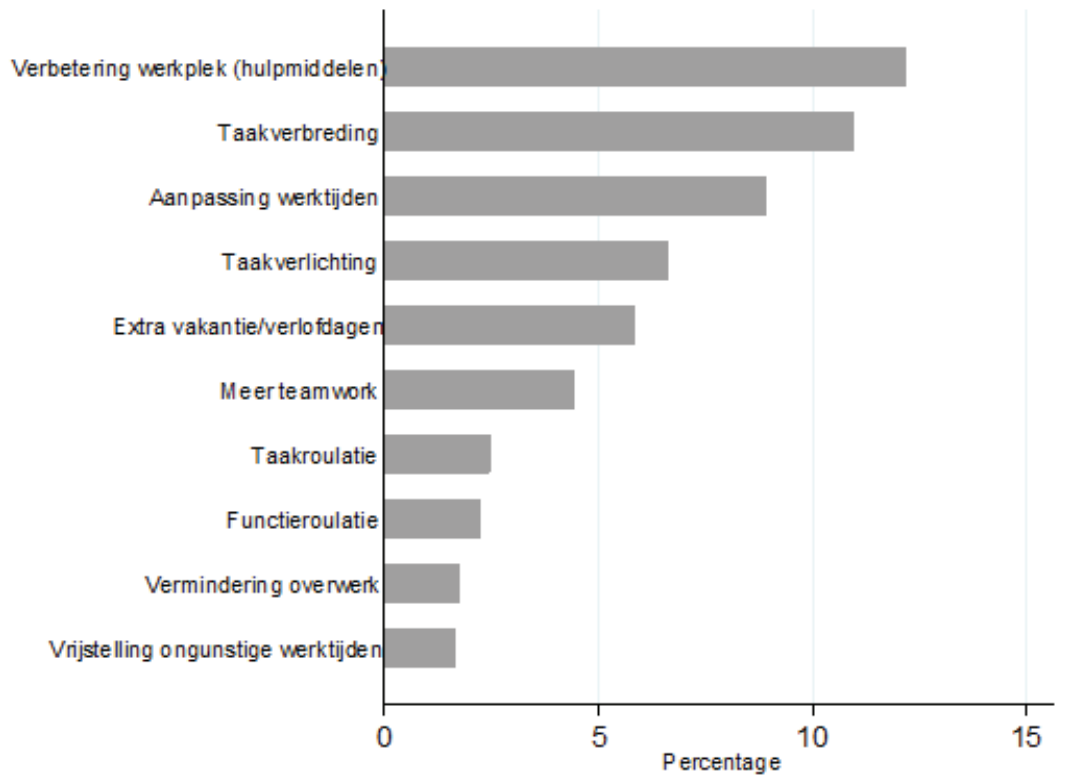

In overeenstemming met de resultaten uit figuur 4.6 blijkt uit figuur 4.7 dat weinig werknemers aangeven dat hun werkgever bereid is om hun taakbelasting aan te passen. Dit geldt zowel voor de geestelijke als fysische taakbelasting. Maar 34,5\% respectievelijk $37,8 \%$ is het eens met de stelling dat hun werkgever bereid zal zijn om hun geestelijke of fysische taakbelasting aan te passen als dat nodig. Ruim $26,1 \%$ en $20,9 \%$ geeft daarentegen aan dat hun werkgever hiertoe geenszins toe bereid is.

Het meest opvallend is echter dat werknemers vrij negatief oordelen over de stelling dat hun werkgever meer aandacht is gaan besteden om oudere werknemers langer in dienst te houden. Ruim 4I,4\% van alle werknemers geeft zelfs aan dat zij het (zeer) oneens zijn met deze stelling. Dit suggereert dat werkgevers niet in voldoende mate aandacht hebben besteed aan leeftijdsbewust personeelsbeleid, ondanks de veranderingen in het pensioenstelsel. Dit wordt verder onderstreept door het feit dat oudere werknemers ook vaker een alternatieve mogelijkheid tot eerder uittreden krijgen aangeboden door hun werkgever. Verder valt op dat oudere werknemers ook structureel negatiever oordelen over het personeelsbeleid dan jongere cohorten. Alleen wat betreft de waardering van hun leidinggevende zijn ze niet significant negatiever in hun oordeel. 

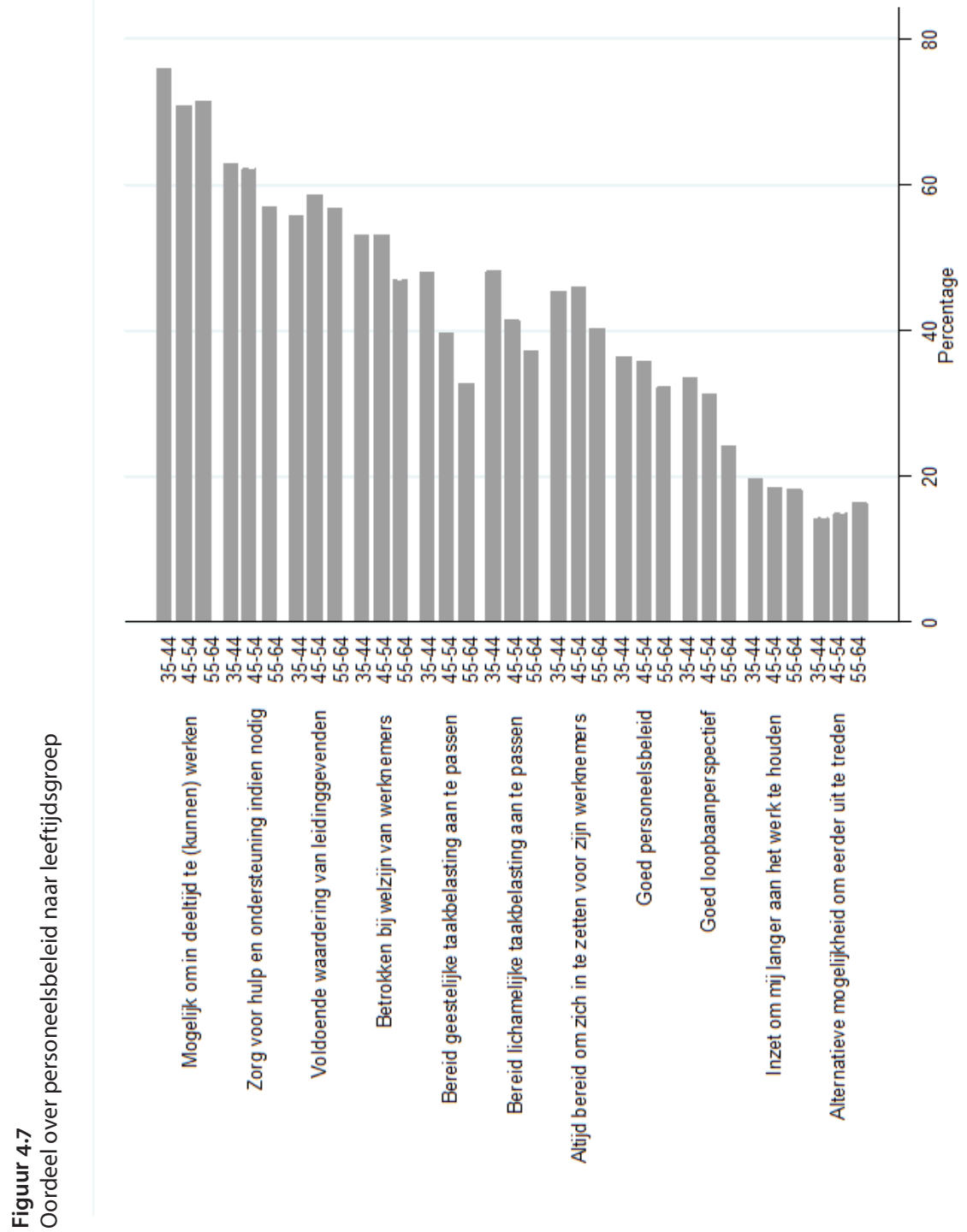

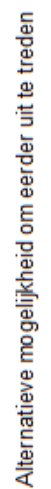


De ontevredenheid van werknemers, het blijven aanbieden van alternatieve uittredemogelijkheden en het feit dat oudere werknemers op bijna alle aspecten van het personeelsbeleid vrij negatief oordelen, duidt er op dat werkgevers nog niet voldoende aandacht besteden aan de employability van het oudere personeel en hun personeelsbeleid beter moeten afstemmen op de wensen van oudere werknemers. Bovendien blijkt uit de percepties van werknemers dat de micro-belangen van hun werkgever zwaarder wegen dan het macro-belang om oudere werknemers te stimuleren om door te werken.

Tabel 4.3

Percentage medewerkers dat tevreden is met personeelsbeleid naar sector

\begin{tabular}{|lll|}
\hline Rijk & $\%$ & $\begin{array}{c}\text { Sig verschil tussen } \\
\text { sectoren }\end{array}$ \\
\hline Defensie burgerpersoneel & 28,4 & 22,2 \\
\hline Provincies en Waterschappen & 42,2 & $* * *$ \\
\hline Gemeenten & 33,0 & $* *$ \\
\hline Politie & 19,5 & $* * *$ \\
\hline Primair onderwijs & 35,0 & $*$ \\
\hline Voortgezet onderwijs & 32,0 & \\
\hline Hoger beroepsonderwijs & 34,7 & $* * *$ \\
\hline Wetenschappelijk onderwijs, onderzoek en wetenschapsbeleid & 25,4 & \\
\hline Beroeps- en volwasseneneducatie & 21,8 & $*$ ** \\
\hline Universitaire medische centra & 33,6 & \\
\hline Water, energie en nutsbedrijven & 42,8 & \\
\hline Vrijwillige toetreders & 30,8 & 26,5 \\
\hline Overig & & \\
\hline
\end{tabular}

\begin{tabular}{|c|c|c|}
\hline Bouw & 39,8 & *** \\
\hline Woningcorporaties & 52,6 & $* * *$ \\
\hline $\begin{array}{l}\text { Totaal } \\
=\text { sianificant or }\end{array}$ & 32,0 & \\
\hline
\end{tabular}

Uit tabel 4.3 blijkt dat personeelsbeleid van de werkgever het best wordt beoordeeld door de werknemers in de sectoren woningcorporaties, water, energie en nutsbedrijven en provincies en waterschappen. Bij de woningcorporaties is zelfs een meerderheid van het personeel tevreden over het door hun werkgever gevoerde personeelsbeleid. Werknemers zijn daarentegen het minst positief bij de politie en de beroeps- en volwasseneneducatie. 
Tabel 4.4 laat zien dat werknemers in de bouwsector en de sectoren defensie en provincies en waterschappen significant vaker aangeven dat hun werkgever zich in de afgelopen jaar meer is gaan inzetten om werknemers langer aan het werk te houden. Echter, zelfs in de bouw gaat het maar om een minderheid van de werknemers die hierover positief oordeelt. Werknemers van woningcorporaties (II,2\%) en het wetenschappelijk onderwijs, onderzoek en wetenschapsbeleid (Io,6\%) geven het minst vaak aan dat hun werkgever zich meer is gaan inzetten om medewerkers langer aan het werk te houden.

\section{Tabel 4.4}

Werkgever is zich het afgelopen jaar meer gaan inzetten om werknemers langer aan het werk te houden, naar sector

\begin{tabular}{|c|c|c|}
\hline & $\%$ & $\begin{array}{l}\text { Sig verschil tussen } \\
\text { sectoren }\end{array}$ \\
\hline Rijk & 13,2 & \\
\hline Defensie burgerpersoneel & 21,3 & *** \\
\hline Provincies en Waterschappen & 20,4 & ** \\
\hline Gemeenten & 14,5 & \\
\hline Politie & 17,2 & \\
\hline Primair onderwijs & 16,2 & \\
\hline Voortgezet onderwijs & 15,5 & \\
\hline Hoger beroepsonderwijs & 12,7 & \\
\hline Wetenschappelijk onderwijs, onderzoek en wetenschapsbeleid & 10,6 & \\
\hline Beroeps- en volwasseneneducatie & 16,6 & \\
\hline Universitaire medische centra & 19,4 & * \\
\hline Water, energie en nutsbedrijven & 18,5 & * \\
\hline Vrijwillige toetreders & 17,7 & \\
\hline Overig & 13,2 & \\
\hline Bouw & 30,8 & $* * *$ \\
\hline Woningcorporaties & 11,2 & \\
\hline $\begin{array}{l}\text { Totaal } \\
=\text { significant op } 10 \% \text {-niveau } \\
* * \\
\text { * significant op }\end{array}$ & $\begin{array}{l}16,5 \\
\text { ifica }\end{array}$ & n-niveau \\
\hline
\end{tabular}

Een belangrijke vraag is natuurlijk in hoeverre er een relatie is tussen de hierboven in kaart gebrachte (on)tevredenheid van werknemers over het door hun werkgever gevoerde personeelsbeleid en de verwachte pensioenleeftijd en productiviteit van werknemers. Uit tabel 4.5 blijkt dat de tevredenheid over het personeelsbeleid in beperkte mate correleert met de verwachte pensioenleeftijd. Hierbij speelt vanzelfsprekend mee dat de verwachte pensioenleeftijd ook van de financiële prikkels in het 
pensioensysteem afhangt. Desalniettemin blijkt dat werknemers langer denken door te werken indien:

- zij de mogelijkheid hebben om in deeltijd te werken;

- zij ervaren dat hun werkgever betrokken is bij hun welzijn;

- de werkgever bereid is om hun geestelijke taakbelasting aan te passen als dat noodzakelijk zou zijn.

Het is weinig verrassend dat de kans om met deeltijdpensioen te gaan in sterke mate afhangt van de mogelijkheden die de werkgever biedt om in deeltijd te werken en met de alternatieve mogelijkheden die de werkgever biedt om eerder uit te treden. Zoals uit tabel 3.5 bleek wordt de mogelijkheid om deeltijdpensionering (met doorbetaling van de pensioenpremie op voltijdsbasis) vaak door werkgevers aan oudere medewerkers aangeboden om alsnog vervroegde uittrede te bewerkstelligen.

Voor wat betreft de werkinzet valt op dat de waardering van leidinggevenden een zeer belangrijke factor is. Een hoger gevoel van waardering leidt tot minder ziektedagen, en een hogere baantevredenheid en bevlogenheid. Daarnaast is er een sterk significant positief verband tussen het loopbaanperspectief en de gepercipieerde bereidheid van werkgevers om zich in te zetten voor hun werknemers en de baantevredenheid en bevlogenheid van de medewerkers. De mogelijkheid om in deeltijd te gaan werken en een goed oordeel over het personeelsbeleid dragen eveneens bij aan een hogere baantevredenheid.

Verder vinden wij een significante positieve relatie tussen de alternatieve mogelijkheden om eerder uit te treden en de bevlogenheid van werknemers. Aangezien bevlogen mensen juist gemiddeld genomen later met pensioen denken te gaan, is het opvallend dat het hebben van alternatieve mogelijkheden om eerder uit te treden positief gecorreleerd is aan de bevlogenheid. Een mogelijke verklaring zou kunnen zijn dat bevlogen werknemers wellicht door de alternatieve mogelijkheden om eerder uit te treden in staat worden gesteld om andere activiteiten op te zetten of als zelfstandig deskundige te kunnen worden ingehuurd. Een andere optie is dat bevlogen werknemers de vrijheid waarderen die zij hebben in het kiezen van hun pensioendatum, maar niet per definitie eerder met pensioen wensen te gaan. 


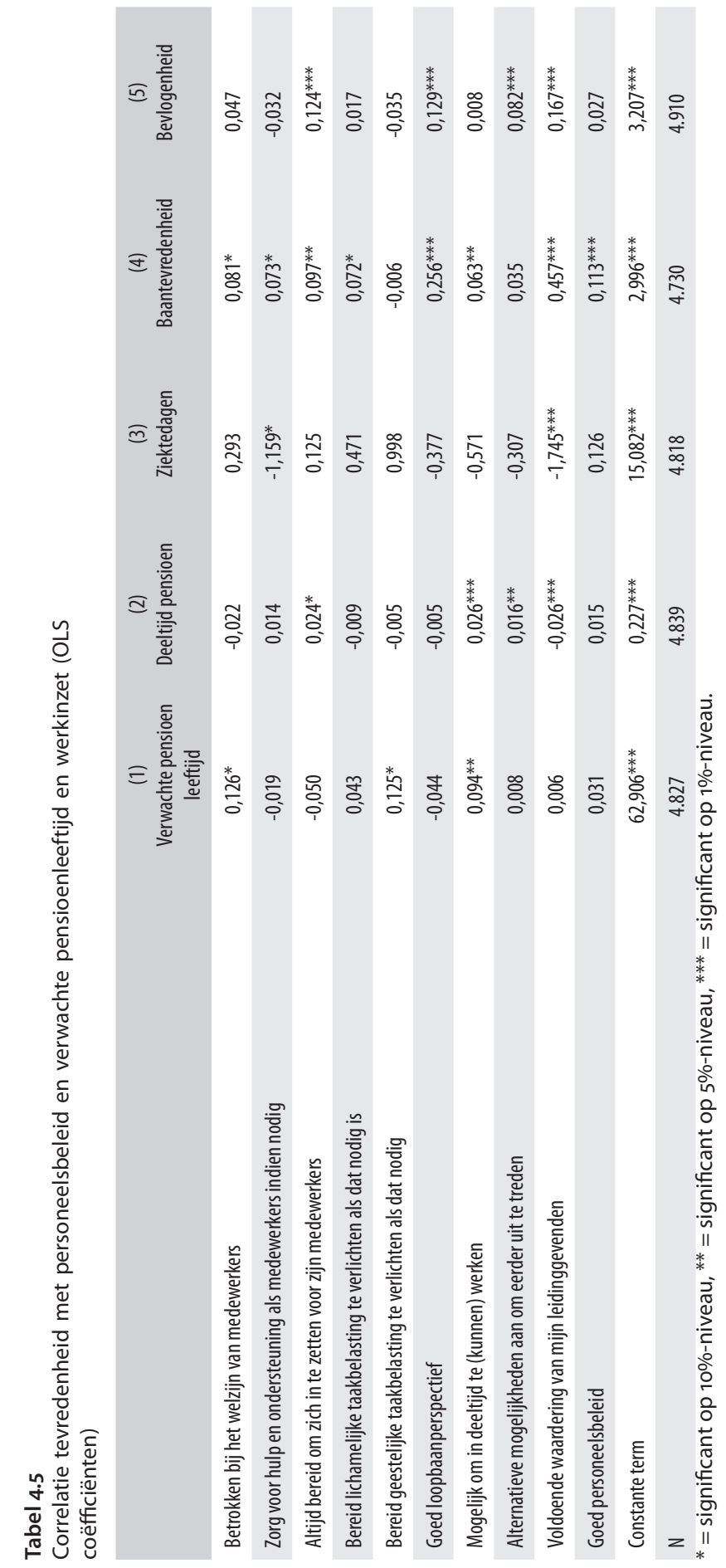




\subsection{Trainingsparticipatie}

In hoeverre hebben werkgevers in de publieke sector initiatieven ontwikkeld om mensen intrinsiek te motiveren om langer door te werken? Een van de belangrijkste faciliteiten die kan bijdragen tot het verhogen van de motivatie en productiviteit van werkenden is trainingsparticipatie. Van Loo et al. (2005) hebben reeds aangetoond dat trainingsparticipatie het plezier in het werk verhoogt, wat een positief effect kan hebben op de motivatie op het werk. ${ }^{28}$ Ook zal training de kennis en/of vaardigheden van werkenden vergroten, waardoor de productiviteit kan toenemen en vaste patronen in het werk die demotiverend werken voor werknemers doorbroken kunnen worden (Henkens en Tazelaar 1994). ${ }^{29}$

\section{Figuur 4.8}

Trainingsparticipatie in het afgelopen jaar

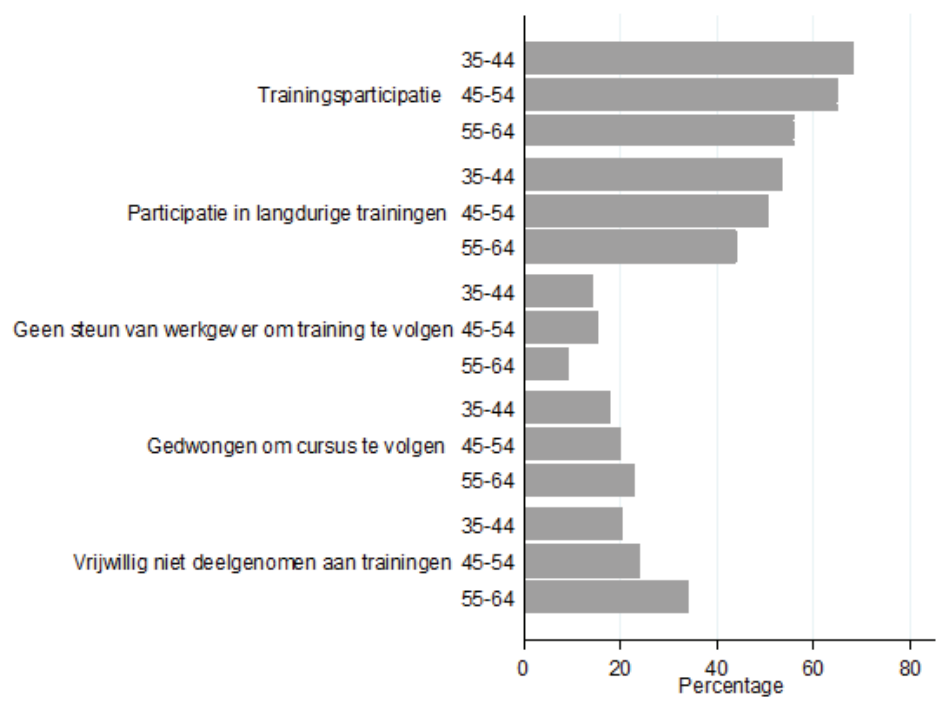

Uit figuur 4.8 blijkt dat er veel getraind wordt. Ruim 69,7\% van alle jongere werknemers heeft het afgelopen jaar een training gevolgd. Ruim 66,3 van deze jongeren heeft een langdurige training gevolgd die langer dan één werkweek duurde. Duidelijk is echter ook dat de trainingsparticipatie afneemt met leeftijd. Van de oudere werknemers heeft $56,8 \%$ het afgelopen jaar een training gevolgd. Bovendien volgen zij minder vaak een langere training $(44,3 \%)$.

28. J. van Loo., A. de Grip en R.. Montizaan (2005). Active aging bij Overheid-en Onderwijs, ROA/ABP, Maastricht/Heerlen.

29. K. Henkens en F. Tazelaar (1994), 'Early retirement of civil-servants in The Netherlands', Journal of Applied Social Psychology, vol. 24(21), pp. 1927-1943. 
De vraag is vervolgens waarom ouderen minder vaak trainingen volgen. Komt dit doordat ouderen minder gemotiveerd zijn om een training te volgen, of doordat hun werkgever niet gemotiveerd is om te investeren in oudere werknemers waarvoor de trainingsinvesteringen minder lang rendement afleveren. Figuur 4.8 laat zien dat de dalende trainingsparticipatie voornamelijk wordt veroorzaakt door een gebrek aan motivatie aan de kant van oudere werknemers. Hoewel niet uit te sluiten valt dat ook de werkgever minder bereid is om te investeren in de scholing van oudere werknemers, laat de figuur duidelijk zien dat oudere werknemers (9,3\%) minder vaak aangeven dan jongere werknemers ( $14,7 \%)$ dat zij beperkt werden om een training te volgen doordat zij geen steun van hun werkgever kregen. Daarentegen is het percentage werknemers dat aangeeft dat zij gedwongen werden door hun werkgever om een cursus te volgen significant groter bij de 55-plussers. Het is daarom weinig verrassend dat het percentage werknemers dat vrijwillig niet heeft deelgenomen aan een training significant groter is bij de oudere medewerkers.

Figuur 4.9 bevestigt het beeld dat vooral het gebrek aan motivatie de oorzaak is voor de lagere trainingsparticipatie van oudere werknemers. Jongere werknemers nemen zelf vaker initiatief om een cursus te volgen, terwijl bij ouderen het initiatief vaker van de werkgever komt.

\section{Figuur 4.9}

Initiatiefnemer training

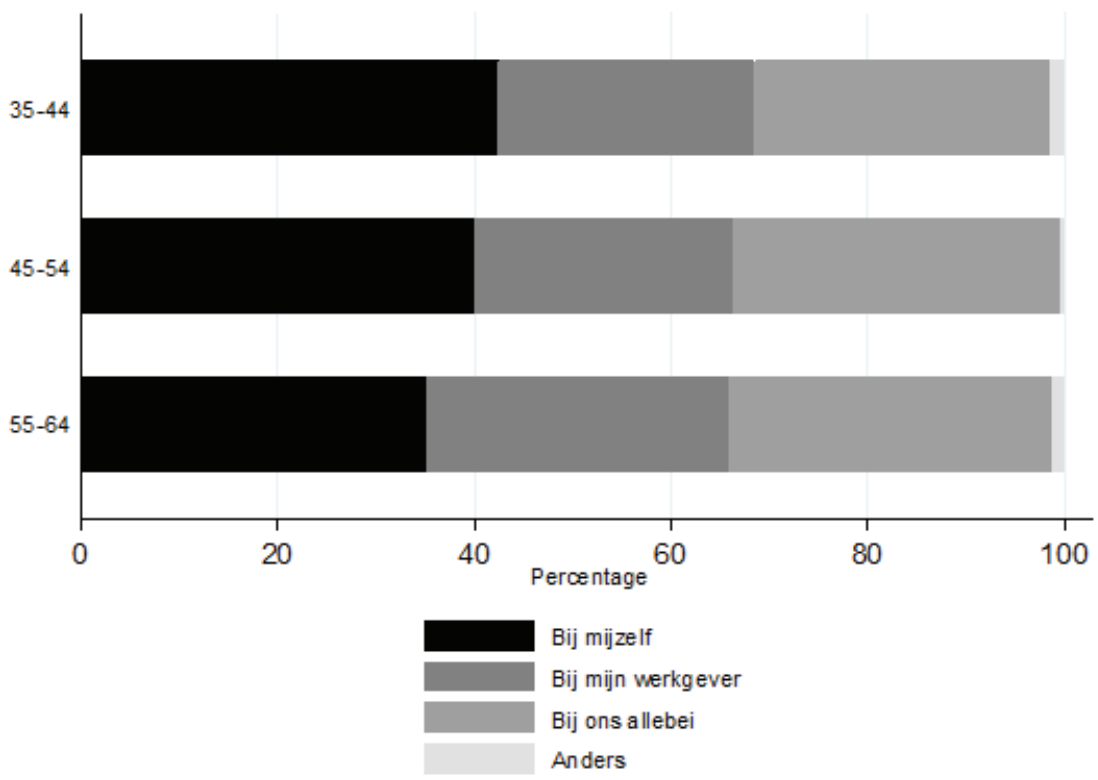


Tabel 4.6 laat ook zien dat er niet in alle sectoren evenveel wordt getraind. Positieve uitschieters zijn het primair onderwijs $(76,9 \%)$, woningcorporaties $(68,0 \%)$ en provincies en waterschappen $(63,9 \%)$. Er wordt daarentegen relatief weinig getraind in het wetenschappelijk onderwijs, onderzoek en wetenschapsbeleid (37,I\%), waarschijnlijk omdat in deze sector mensen vooral op informele wijze leren. Eenzelfde argument geldt voor de bouw $(43,2 \%)$. Daarnaast wordt in de bouwsector de mogelijkheid geboden om vanaf 55 jarige leeftijd één dag per week minder te werken tegen inlevering van o.a. trainingsuren.

\section{Tabel 4.6}

Trainingsparticipatie naar sector

\begin{tabular}{|c|c|c|}
\hline & $\%$ & $\begin{array}{l}\text { Sig verschil tussen } \\
\text { sectoren }\end{array}$ \\
\hline Rijk & 54,6 & \\
\hline Defensie burgerpersoneel & 47,0 & * \\
\hline Provincies en Waterschappen & 63,9 & ** \\
\hline Gemeenten & 58,9 & * \\
\hline Politie & 55,5 & \\
\hline Primair onderwijs & 76,9 & $* * *$ \\
\hline Voortgezet onderwijs & 58,6 & \\
\hline Hoger beroepsonderwijs & 62,1 & ** \\
\hline Wetenschappelijk onderwijs, onderzoek en wetenschapsbeleid & 37,1 & $* * *$ \\
\hline Beroeps- en volwasseneneducatie & 62,6 & ** \\
\hline Universitaire medische centra & 62,6 & * \\
\hline Water, energie en nutsbedrijven & 60,8 & \\
\hline Vrijwillige toetreders & 64,6 & ** \\
\hline Overig & 46,3 & \\
\hline Bouw & 43,2 & $* * *$ \\
\hline Woningcorporaties & 68,0 & $* * *$ \\
\hline $\begin{array}{l}\text { Totaal } \\
=\text { sianificant op } 10 \% \text {-niveau } * *=\text { sianificant op }\end{array}$ & 59,2 & $\sqrt{2}$ \\
\hline
\end{tabular}





\section{Loon en productiviteit}

In dit hoofdstuk wordt ingegaan op de relatie tussen loon en productiviteit en het belang van het doorwerken vanuit het werkgeversperspectief. Daartoe wordt gebruik gemaakt van een enquête onder werkgevers. ${ }^{30}$ Eerst gaan wij in op de verhouding tussen loonkosten en productiviteit naar de leeftijd van werknemers. In paragraaf 5.2 gaan wij in op relatie tussen leeftijd en ander productieve vaardigheden van werknemers. Het belang van langer werken voor de werkgevers komt aan bod in paragraaf 5.3. Wij sluiten het hoofdstuk af met een bespreking van de rol van leeftijd bij het wervingsgedrag van werkgevers.

\subsection{Loonkosten en productiviteit}

In de enquête onder werkgevers is aan de respondenten gevraagd aan de hand van een cijfer tussen I (zeer slecht) en Io (uitmuntend) een waardering te geven voor de prestaties van werknemers in verschillende leeftijdsgroepen (35-44 jaar, 45-54 jaar en 55-64 jaar). De prestaties waarover een oordeel gevraagd wordt dekken een breed terrein van vaardigheden en hebben betrekking op, bijvoorbeeld, productiviteit, kennis, omgaan met technologische veranderingen, en probleemoplossend vermogen. Daarnaast is ook gevraagd om een oordeel te geven over de relatieve loonkosten van werknemers in de betreffende leeftijdsgroepen op eenzelfde schaal lopend van I (zeer laag) tot Io (zeer hoog).

Op basis van administratieve data van het salaris dat organisaties in de overheids- en onderwijssectoren aan hun werknemers betalen (het pensioengevend inkomen) kan een vergelijking worden gemaakt tussen de beloning en de subjectieve waardering van de loonkosten. Figuur 5.I laat zien dat er een positief verband is tussen het betaalde loon en de subjectieve waardering van de loonkosten voor de verschillende leeftijdsgroepen. De elasticiteit van het cijfer voor loonkosten voor de 55-64 jarigen t.o.v. $35-44$ jarigen bedraagt $38 \%$. Voor de feitelijke loonkosten is de elasticiteit $35 \%$. Hierbij dienen echter twee kanttekeningen geplaatst te worden. Ten eerste zijn de verschillen in de gepercipieerde loonkosten van 55-64 jarigen t.o.v. 35-44 jarigen binnen organisaties niet significant gecorreleerd met de feitelijke verschillen in de loonkosten. In

30. Bij elke organisatie is een persoon benaderd. Doorgaans gaat het om de directeur (vooral bij kleine organisaties) of de leidinggevende op het terrein van HR (vooral bij grotere organisaties). Het aantal deelnemende werkgevers per sector is weergegeven in tabel B.r in de bijlage. 
veel bedrijven zijn de loonkosten van oudere werknemers niet veel hoger dan die van jongere werknemers, maar de werkgever geeft wel aan dat hij deze kosten relatief hoog vindt. In andere bedrijven zijn de loonkosten van oudere werknemers relatief hoog terwijl de werkgever niet aangeeft dat hij de kosten hoog vindt. Ten tweede, lijkt het er op dat werkgevers de loonkosten voor de oudste leeftijdsgroep naar verhouding hoger inschat dan de feitelijk loonkosten. ${ }^{3 \mathrm{I}}$ Voorzichtigheid is dus geboden bij het interpreteren van de subjectieve waardering van de relatieve loonkosten.

\section{Figuur 5.1}

Relatie tussen de subjectieve waardering van de loonkosten en het feitelijke loon voor verschillende leeftijdsgroepen

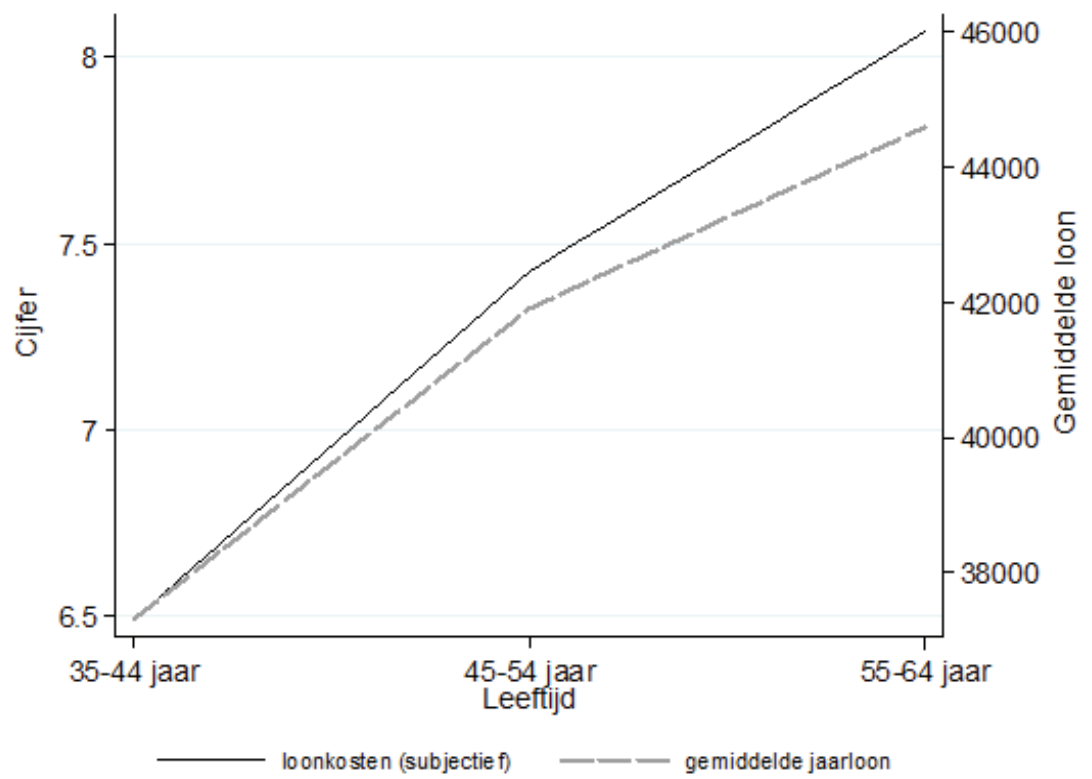

In figuur 5.2 vergelijken wij de perceptie van de loonkosten met de waardering van de productiviteit per leeftijdsgroep. De productiviteit in de leeftijdsgroepen 35-44 jaar en 45-54 jaar wordt op ongeveer hetzelfde niveau gewaardeerd (respectievelijk 7,6 en 7,7 ). De productiviteit van 55-plussers wordt daarentegen met een 7,2 significant lager gewaardeerd. Vooral werkgevers in de bouw $(6,9)$, provincies en waterschappen $(6,9)$, de beroeps- en volwasseneneducatie $(6,9)$, de politie $(6,8)$ en de schoonmaak- en glazenwassersbedrijven $(6,8)$ geven gemiddeld een lage waardering voor de productiviteit van werknemers in de leeftijdsgroep van 55-64 jaar.

3I. Het is interessant om op te merken dat recent onderzoek heeft laten zien dat het loon op latere leeftijd nauwelijks verschilt tussen openbaar bestuur en de marktsector (zie A. Deelen, R. Euwals en I. Specker, 20II, De mobiliteit van ouderen ambtenaren, ESB, $96(4622): 682-683)$. 
Omdat de gemiddelde loonkosten oplopen naarmate mensen ouder zijn, verschuift de verhouding tussen de productiviteit en loonkosten voor opeenvolgende leeftijdsgroepen van een positieve verhouding voor de leeftijdsgroep 35-44 jaar in een negatieve verhouding voor de leeftijdsgroep 55-64 jaar. Zoals hierboven werd opgemerkt, moet men kan zich echter afvragen of de respondenten een goed beeld hebben van de feitelijke loonkosten.

Figuur 5.2

Subjectieve waardering van productiviteit en loonkosten (op schaal van 1 tot 10) per leeftijdsgroep

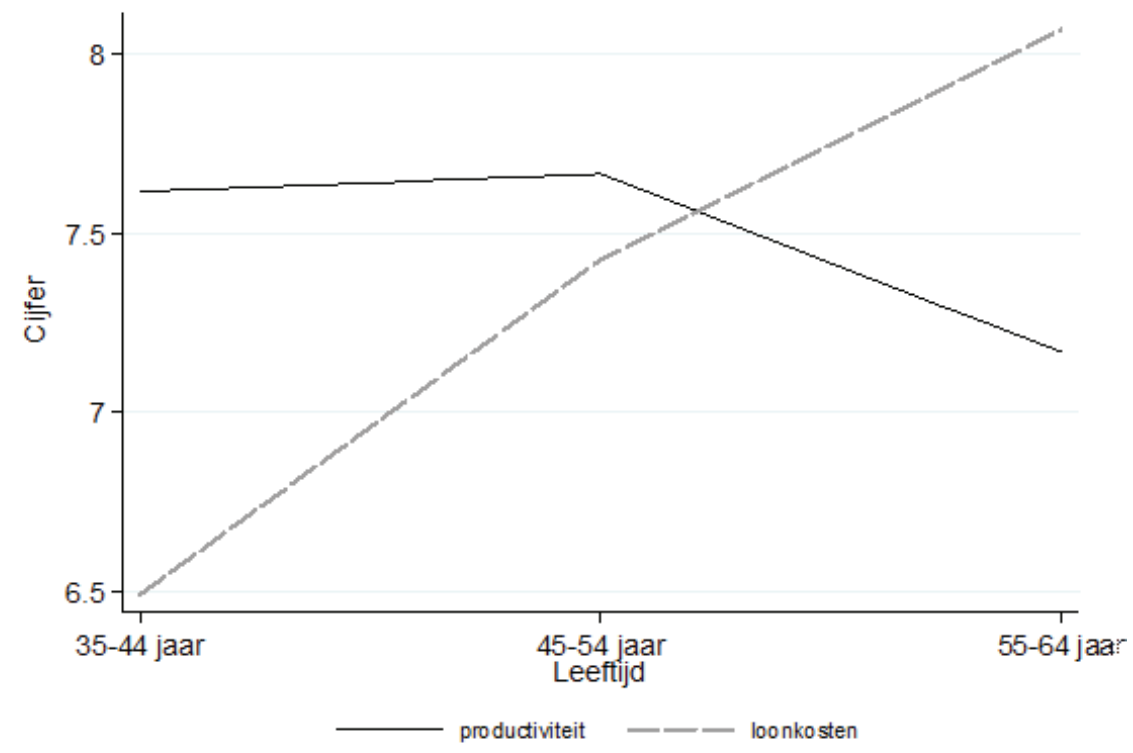

Tabel 5.I laat de resultaten zien van een analyse van het verschil tussen de gepercipieerde productiviteit en loonkosten voor de drie leeftijdsgroepen in de verschillende sectoren. In alle sectoren pakt het verschil tussen productiviteit en loonkosten positief uit voor de jongste leeftijdsgroep. Voor de groep 35-44 jarigen is het cijfer die werkgevers voor de productiviteit geven I, I punt hoger dan het cijfer die zij geven voor de loonkosten. Dit betekent dat voor deze leeftijdsgroep de baten (productiviteit) hoger uitkomen dan de gepercipieerde kosten (loon). Voor de 45-54 jarigen is de productiviteit daarentegen over het algemeen min of meer in lijn met de loonkosten. Gemiddeld over alle sectoren bedraagt het verschil tussen de productiviteit en loonkosten slechts 0,3 op de schaal van I tot Io. Voor 4 sectoren (provincies en waterschappen, voortgezet onderwijs, beroeps- en volwasseneneducatie en woningcorporaties) is de waardering van de productiviteit van 45-54 jarigen nagenoeg gelijk (verschil in o,I punt of kleiner) aan de waardering van de loonkosten. Voor de leeftijdsgroep 55-64 jarigen, is de beoordeling van de productiviteit ten opzichte van de loonkosten 0,9 punt lager. Het verschil in waardering tussen productiviteit en loon van 55-64 jarigen is vooral groot 
bij de politie (-I,4 punt) en het beroeps- en volwassenenonderwijs (-I,4 punt). ${ }^{32}$ Het verschil is het kleinst bij het hoger beroepsonderwijs (-0,3 punt), de vrijwillige toetre$\operatorname{der}^{33}$ (-0,5 punt) en de groep overige (-0,5 punt). ${ }^{34}$ Opvallend is dat in de schoonmaak- en glazenwassersbedrijven de subjectieve waardering van de loonkosten van de 55-64 jarigen in evenwicht lijkt met de subjectieve waardering van de productiviteit.

\section{Tabel 5.1}

Verschil tussen subjectieve waardering van productiviteit en loonkosten (op schaal van 1 tot 10) tussen verschillende leeftijdsgroepen, naar sector*

\begin{tabular}{|lcccc} 
& $35-44$ jaar & $45-54$ jaar & $55-64$ jaar & N \\
\hline Rijk & 1,1 & 0,2 & $-1,0$ & 15 \\
\hline Provincies en waterschappen & 1,0 & 0,0 & $-1,1$ & 31 \\
\hline Gemeenten & 1,0 & 0,2 & $-0,8$ & 225 \\
\hline Politie & 0,8 & $-0,3$ & $-1,4$ & 8 \\
\hline Primair onderwijs & 1,3 & 0,3 & $-1,0$ & 241 \\
\hline Voortgezet onderwijs & 1,1 & 0,1 & $-1,2$ & 73 \\
\hline Hoger beroepsonderwijs & 1,5 & 0,7 & $-0,3$ & 15 \\
\hline Wetenschappelijk onderwijs, onderzoek en wetenschapsbeleid & 1,5 & 0,4 & $-0,8$ & 17 \\
\hline Beroeps- en volwasseneneducatie & 1,2 & 0,0 & $-1,4$ & 18 \\
\hline Universitaire medische centra & 1,0 & $-0,5$ & $-1,5$ & 2 \\
\hline Water, energie en nutsbedrijven & 1,0 & 0,1 & $-1,1$ & 25 \\
\hline Vrijwillige toetreders & 1,1 & 0,3 & $-0,5$ & 94 \\
\hline Overige & 1,3 & 0,4 & $-0,5$ & 16 \\
\hline Bouw & 1,0 & 0,3 & $-1,0$ & 81 \\
\hline Woningcorporaties & 0,5 & $-0,1$ & $-1,0$ & 37 \\
\hline Schoonmaak- en glazenwassersbedrijven & 1,0 & 0,7 & 0,0 & 26 \\
\hline *otaal & 1,1 & 0,3 & $-0,9$ & 924 \\
\hline
\end{tabular}

32. Bij de politie is het loonprofiel (subjectieve inschatting van de werkgevers) niet anders dan in andere sectoren. De waardering van de productiviteit van ouderen ligt wel lager dan in andere sectoren. In het beroeps- en volwassenenonderwijs is vooral sprake van een steiler lopend loonprofiel dan gemiddeld volgens de inschatting van de werkgevers.

33. De sector vrijwillige toetreders is vrij heterogeen. De grootste werkgevers in deze sector zijn Haven bedrijf Rotterdam, Dyade en Stichting APS. De groep 'overige' is eveneens heterogeen en omvat o.a. het Kadaster, HTM Personenvervoer, Schiphol Nederland als grootste werkgevers.

34. De sectoren universitaire medische centra (kleine aantallen) en overige zullen in het vervolg van dit hoofdstuk worden opgenomen in de tabellen, maar de resultaten worden niet in de tekst besproken. 


\subsection{Productieve vaardigheden}

Figuur 5.2 en tabel 5.I suggereren dat er voor het oudere personeel in de overheidsen onderwijssectoren een kloof bestaat tussen de productiviteit en de loonkosten. Op een aantal belangrijke productieve vaardigheden blijken oudere werknemers het echter niet slechter en soms zelfs beter te doen dan jongere werknemers. Zo blijkt uit tabel 5.2 dat 55-64 jarigen het beter doen dan werknemers in de leeftijd van 35-44 jaar voor wat betreft hun kennisniveau, deskundigheid, zelfstandigheid, nauwkeurigheid, planning van het werk, leidinggeven en het omgaan met verantwoordelijkheid. Ook doen oudere werknemers volgens de werkgevers het niet slechter als het gaat om hun probleemoplossend vermogen, communicatieve vaardigheden, klantgerichtheid, samenwerken met collegae en stressbestendigheid. Daar staat echter tegenover dat 55-64 jarigen wel slechter scoren dan 35-44 jarigen als het gaat om hum omgang met organisatorische veranderingen, omgang met technologische veranderingen, commerciële vaardigheden en flexibiliteit.

Tabel 5.2

Subjectieve waardering (op schaal van 1 tot 10) van productieve vaardigheden, naar leeftijdsgroep (gesorteerd naar verschil tussen 55-64 jarigen en 35-44 jarigen)

\begin{tabular}{|llll} 
& $35-44$ jaar & $45-54$ jaar & $55-64$ jaar \\
\hline Omgaan met verantwoordelijkheid & 7.2 & 7.7 & 7.8 \\
\hline Kennis & 7.3 & 7.7 & 7.8 \\
\hline Leidinggeven & 7.0 & 7.4 & 7.4 \\
\hline Zelfstandigheid & 7.3 & 7.7 & 7.7 \\
\hline Deskundigheid / professionaliteit & 7.3 & 7.7 & 7.6 \\
\hline Nauwkeurigheid & 7.2 & 7.5 & 7.5 \\
\hline Planning van het werk & 7.2 & 7.5 & 7.4 \\
\hline Probleemoplossend vermogen & 7.3 & 7.5 & 7.3 \\
\hline Klantgerichtheid & 7.2 & 7.3 & 7.2 \\
\hline Communicatieve vaardigheden & 7.3 & 7.4 & 7.2 \\
\hline Stressbestendigheid & 7.2 & 7.3 & 7.1 \\
\hline Omgang / samenwerken met collegae & 7.4 & 7.5 & 7.3 \\
\hline Commerciële vaardigheden & 6.9 & 6.7 & 6.5 \\
\hline Flexibiliteit & 7.4 & 7.3 & 6.7 \\
\hline Omgaan met organisatieveranderingen & 7.5 & 6.9 & 6.3 \\
\hline Omgaan met technologische veranderingen & 7.9 & 7.1 & 6.2 \\
\hline
\end{tabular}




\subsection{Het belang van langer doorwerken voor de organisaties}

In hoofdstuk I werd het maatschappelijk en economisch belang van het langer doorwerken onderstreept. In het licht van de zojuist besproken relatie tussen productieve vaardigheden en loonkosten kan men zich echter afvragen hoe belangrijk het eigenlijk is voor de personele bezetting van bedrijven dat oudere werknemers langer doorwerken. Figuur 5.3 laat zien dat slechts $17 \%$ van de werkgevers vindt dat het voor de personele bezetting belangrijk tot zeer belangrijk is dat oudere werknemers langer doorwerken. Maar liefst $43 \%$ van de organisaties vindt dit daarentegen onbelangrijk tot zeer onbelangrijk.

\section{Figuur 5.3}

Hoe belangrijk is het voor de organisatie dat oudere werknemers langer doorwerken?

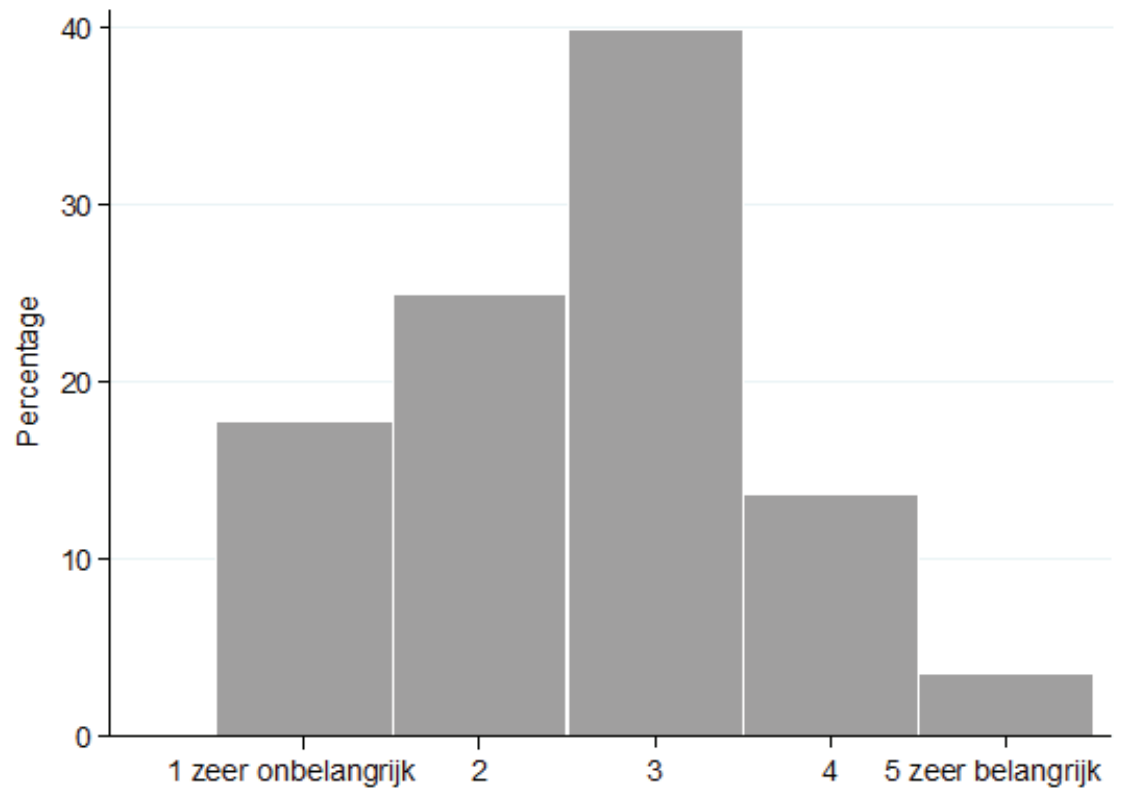

Figuur 5.4 laat zien dat het belang van het langer doorwerken door oudere werknemers voor de organisatie sterk verschilt naar sector. In het voortgezet onderwijs, bij water energie en nutsbedrijven en de politie vindt men het vaakst (zeer) belangrijk voor de personele bezetting van de organisatie dat oudere medewerkers langer doorwerken. Echter, in het primair onderwijs, onder de vrijwillige toetreders en bij de provincie en waterschappen vinden ruim $40 \%$ organisaties het (zeer) onbelangrijk dat ouderen langer doorwerken. Opmerkelijk is het feit dat er geen significant correlatie is tussen het aandeel 55-plussers in de organisatie (terwijl dit een teken van vergrijzing van het werknemersbestand is, waarbij de vervangingsvraag op niet al te lange termijn zal spelen) en het oordeel van de werkgevers over het belang van langer doorwerken. 
Figuur 5.4

Hoe belangrijk voor organisatie dat oudere werknemers langer doorwerken? (naar sector)

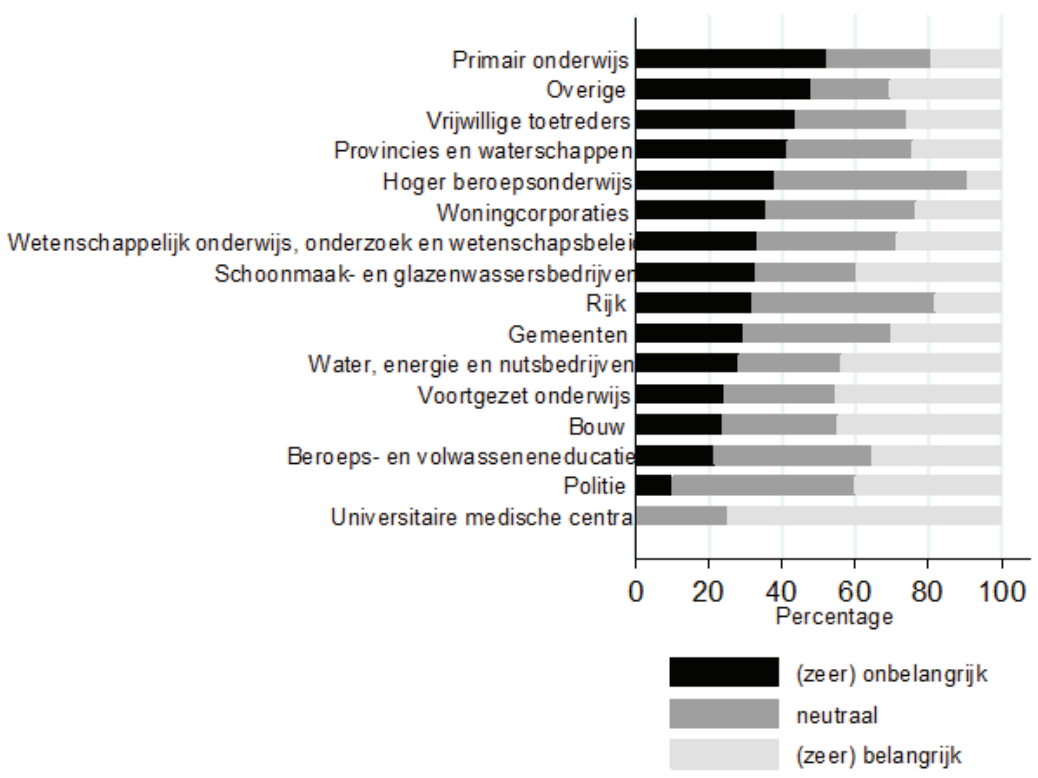

Het langer werken van oudere werknemers kan bepaalde voor- en nadelen hebben. Figuur 5.5 laat zien dat de meerderheid van de werkgevers de grotere vakkennis en ruimere ervaring van oudere werknemers noemt als voordelen van het langer in dienst te houden van oudere werknemers. Een ander aspect dat vaak wordt genoemd is de mentorfunctie die oudere werknemers kunnen vervullen. De ruimere ervaring van oudere medewerkers wordt echter minder vaak als voordeel genoemd in de schoonmaak- en glazenwassersbedrijven, maar verassend genoeg ook in het primair en voortgezet onderwijs en de sector vrijwillige toetreders (tabel B.2 in de bijlage). De grotere vakkennis speelt duidelijk een minder belangrijke rol in de schoonmaak- en glazenwassersbedrijven, het primair onderwijs en de beroeps- en volwasseneneducatie. In het primair onderwijs ziet zelfs een kwart van de scholen geen enkel voordeel in het langer in dienst houden van oudere werknemers. 


\section{Figuur 5.5}

Voordelen om oudere werknemers langer in dienst te houden

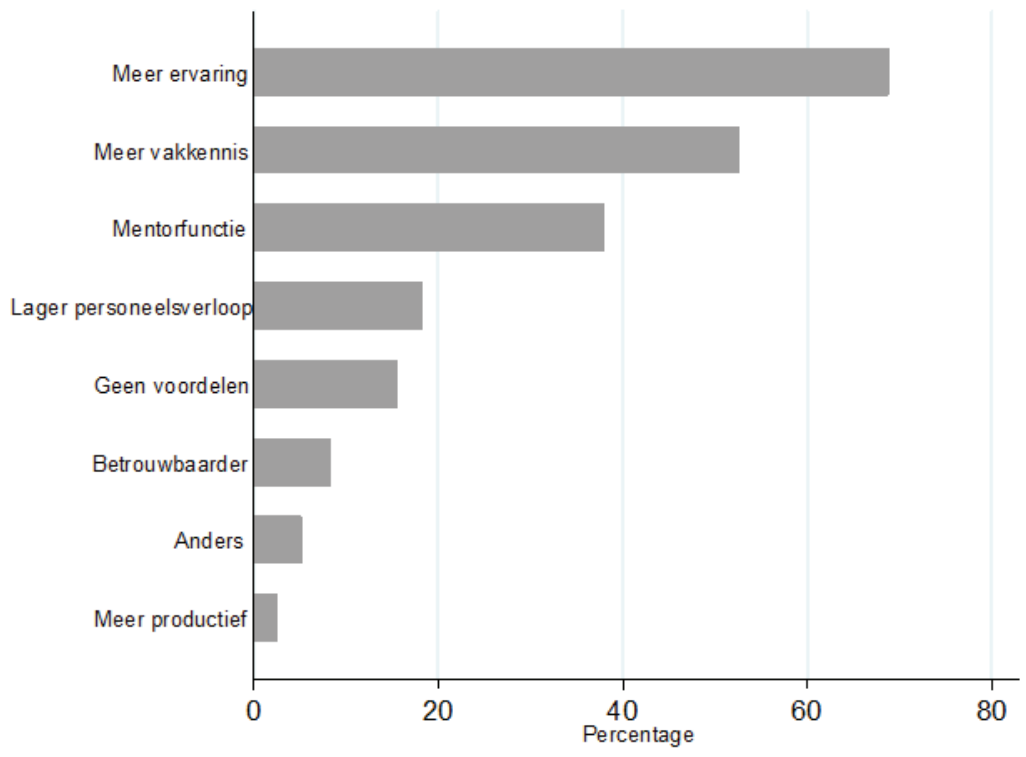

Uit figuur 5.6 blijkt dat slechts $15 \%$ van de werkgevers in de overheids- en onderwijssectoren geen enkele belemmering ziet om ouderen langer in dienst te houden. Dit percentage is hoger dan gemiddeld in het hoger beroepsonderwijs, bij de vrijwillige toetreders, maar ook bij woningcorporaties en de schoonmaak- en glazenwassersbedrijven (zie tabel B.3 in de bijlage). De hoge loonkosten worden het vaakst als belemmering genoemd om oudere werknemers langer in dienst te houden (zie ook figuur 5.I). Dat oudere werknemers duur zijn wordt het vaakst aangegeven door werkgevers in het voortgezet onderwijs, de beroeps- en volwasseneneducatie en bij water, energie en nutsbedrijven. Daarnaast wordt door de werkgevers vaak aangegeven dat oudere werknemers zelf niet langer willen doorwerken. Dat werknemers zelf niet langer door willen werken wordt vaak door water, energie en nutsbedrijven, het beroeps- en volwassenenonderwijs en de gemeenten als belemmering genoemd.

Gezondheidsrisico's worden door ongeveer een derde van de werkgevers genoemd als belemmering om oudere werknemers langer in dienst te houden. De politie, de bouw en water, energie en nutsbedrijven zijn op dit punt duidelijk uitschieters. Voor ruim I op de 5 organisaties speelt de gedachte dat ouderen minder productief zijn of dat hun basisvaardigheden niet up-to-date zijn een rol. 


\section{Figuur 5.6}

Belemmeringen om oudere werknemers langer in dienst te houden

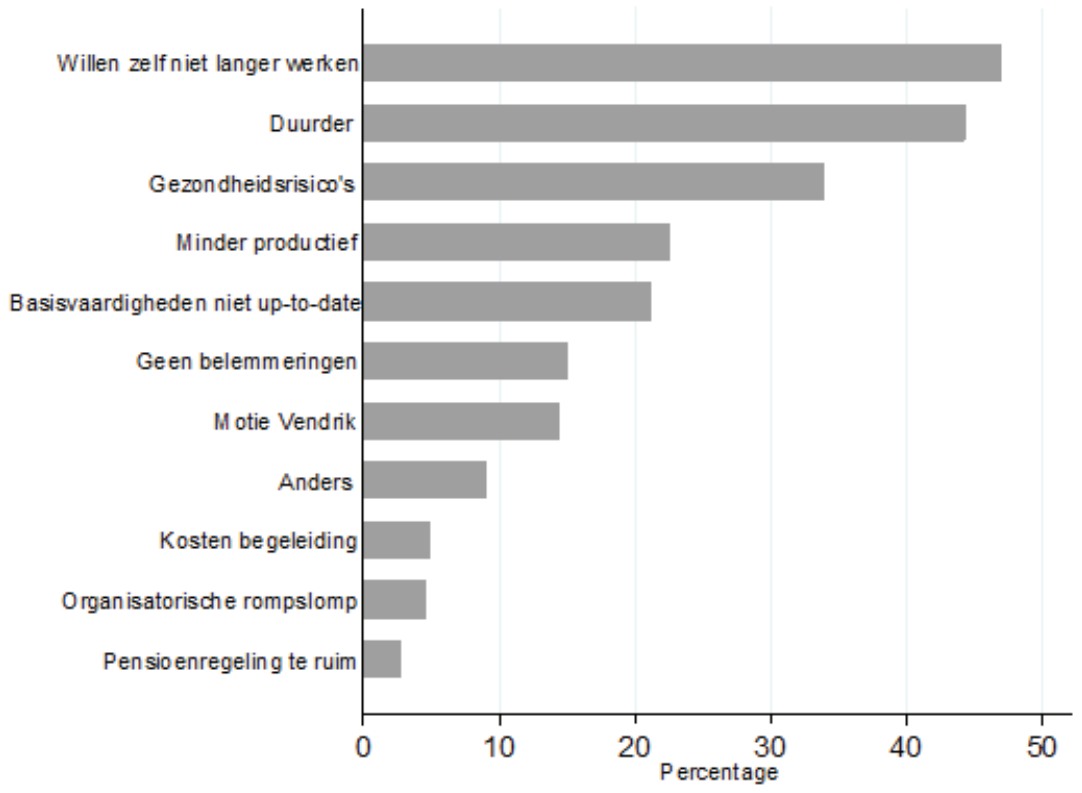

\subsection{Rol van leeftijd bij voorkeur voor sollicitanten}

Op grond van de verschillen in de door werkgevers gepercipieerde productieve vaardigheden tussen jongere en oudere medewerkers kan men zich afvragen in welke mate leeftijd een rol speelt bij het aannamebeleid van werkgevers. Om dit te onderzoeken is in een zogenaamd vignetonderzoek aan iedere organisatie zes keer gevraagd om een keuze te maken tussen twee sollicitanten, waarbij de kenmerken van de sollicitanten in een willekeurige volgorde zijn gepresenteerd. ${ }^{35}$ Deze sollicitanten verschillen op de volgende kenmerken: leeftijd ( 35 jaar, 45 jaar, 55 jaar of 60 jaar), jaren ervaring in een vergelijkbare baan (geen, 5 jaar, Io jaar of meer) en het niveau van hun kennis en vaardigheden (geen bijscholing nodig, korte bijscholing nodig om vaardigheden up-to-date te krijgen, aanzienlijke bijscholing nodig om vaardigheden up-to-date te krijgen).

Uit de analyses van de antwoorden blijkt dat iemands leeftijd en de noodzaak tot bijscholing een belangrijke rol spelen bij de kans om aangenomen te worden (tabel 5.3). Bij een keuze tussen twee sollicitanten heeft een sollicitant van 35 jaar $68 \%$ kans om aangenomen te worden, terwijl een 6o-jarige sollicitant slechts een kans van $27 \%$

35. De volgorde van de kenmerken op vignet heeft geen significante invloed op de keuze. 
heeft om de baan te krijgen. Voor een sollicitant die geen bijscholing nodig heeft is de kans $70 \%$ dat hij of zij zal worden aangenomen. Bij een sollicitant die aanzienlijke bijscholing nodig heeft is de kans slechts $20 \%$.

\section{Tabel 5.3}

Kans dat sollicitant de voorkeur krijgt, naar kenmerken van de sollicitant

\begin{tabular}{ll|}
\hline & Kans \%* \\
\hline Leeftijd & 68 \\
\hline 35 jaar & 61 \\
\hline 45 jaar & 44 \\
\hline 55 jaar & 27 \\
\hline 60 jaar & \\
\hline Ervaring & 33 \\
\hline Geen & 57 \\
\hline 5 jaar & 60 \\
\hline 10 jaar of meer & \\
\hline Bijscholing & 70 \\
\hline Geen bijscholing nodig & 60 \\
\hline Korte bijscholing nodig & 20 \\
\hline Aanzienlijke bijscholing nodig & 1139 \\
\hline Aantal organisaties & \\
\hline Marginale effecten uit probit model. Een kans van 1 betekent dat de sollicitant met het betref- \\
fende kenmerk zeker aangenomen wordt. Een kans van o betekent dat de sollicitant met het \\
betreffende kenmerk zeker niet aangenomen wordt.
\end{tabular}

Op basis van de in tabel 5.3 gepresenteerde uitkomsten, kan een beeld gegeven worden van de kansen van verschillende groepen oudere werknemers om een baan te krijgen ten opzichte van die van jongere werknemers. Een sollicitant van 35 jaar zonder ervaring, maar die geen bijscholing nodig heeft, heeft bij een keuze uit twee kandidaten een kans van $75 \%$ om de baan te krijgen (tabel 5.4; de resultaten zijn ook grafisch weergegeven in figuur 5.7). Deze kans daalt respectievelijk naar $44 \%$ en $23 \%$ voor sollicitanten van 55 jaar en 60 jaar met dezelfde kenmerken. Voor een sollicitant van 55 jaar blijken 5 jaar ervaring voldoende te zijn voor een vergelijkbare kans op de baan ten opzichte van de 35-jarige sollicitant zonder ervaring. Voor een 60-jarige wordt de kans om de baan te krijgen groter wanneer deze meer ervaringsjaren heeft, maar zelfs met Io jaar of meer ervaring is de kans om de baan te krijgen nog steeds aanzienlijk lager dan de kans voor de sollicitant van 35 jaar zonder ervaring. Deze modelschattingen maken duidelijk dat na 55 jaar iemands werkervaring de achterstand op de kans om aangenomen te worden niet meer kan compenseren wanneer men concurreert met een jongere sollicitant zonder ervaring. Dit betekent dat het voor oudere werknemers van groot belang is dat zij in hun huidige baan blijven werken. De kansen op een 
andere baan zijn immers klein. Dit betekent ook dat wanneer oudere werknemers werkloos worden, de kans erg klein is dat zij weer aan het werk komen.

\section{Tabel 5.4}

Geschatte kans dat sollicitant die geen bijscholing behoeft de voorkeur krijgt, naar leeftijd en jaren ervaring (procenten)

\begin{tabular}{lccc} 
& & Ervaring & \\
Leeftijd & Geen & 5 jaar & 10 jaar of meer \\
& $\%$ & $\%$ & 95 \\
\hline 5 jaar & 75 & 94 & 92 \\
\hline 40 jaar & 66 & 90 & 79 \\
\hline 55 jaar & 44 & 76 & 58 \\
\hline 60 jaar & 23 & 54 & 95 \\
\hline
\end{tabular}

\section{Figuur 5.7}

Geschatte kans dat sollicitant die geen bijscholing behoeft de voorkeur krijgt, naar leeftijd en jaren ervaring (procenten)

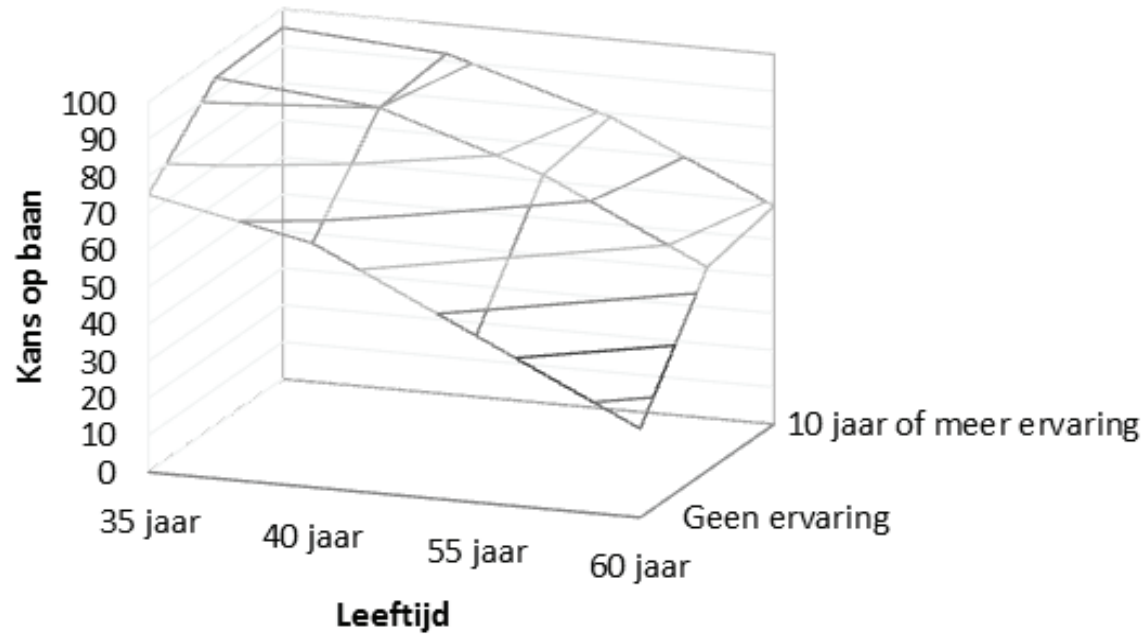

Uit de analyses blijkt dat sectorverschillen in het effect van leeftijd op de kans om de baan te krijgen klein zijn: alleen in het hoger beroepsonderwijs speelt de leeftijd een minder belangrijke rol dan in andere sectoren, maar zelfs daar blijkt de kans op de baan daalt met het stijgen van de leeftijd van de sollicitant. 
Het negatieve effect van iemands leeftijd op de kans om de baan te krijgen is groter naarmate de werkgever vindt dat er in het algemeen een groot verschil is tussen de productiviteit van oudere en jongere werknemers (zie ook figuur 5.2). Een positief oordeel over de kennis van oudere werknemers, één van de productieve vaardigheden waar ouderen beter op scoren dan jongeren (tabel 5.2), heeft daarentegen geen significante effect op de kans dat de werkgever een oudere sollicitant aanneemt. De kans dat een oudere sollicitant gekozen wordt hangt ook niet af van het percentage oudere werknemers (percentage 55-plussers in het personeelsbestand) in de organisatie. 


\section{Beoordeling van personeelsbeleid door werkgevers}

Uit onderzoek naar CAO's komt naar voren dat de thema's duurzame inzetbaarheid, langer doorwerken en levensfasebeleid duidelijk op de agenda staan. ${ }^{36} \mathrm{Er}$ zijn echter grote verschillen tussen sectoren. Bovendien zijn de CAO's op bepaalde punten slechts richtinggevend en het feitelijk beleid zal dan ook vaak op het niveau van organisaties definitief moeten worden vormgegeven. In dit hoofdstuk staat het gevoerde personeelsbeleid centraal. In paragraaf 6.I staan wij stil bij de ingezette HR instrumenten. Paragraaf 6.2 spitst zich toe op het personeelsbeleid gericht op oudere werknemers. Wij sluiten dit hoofdstuk af met een beschouwing van ingezette scholingsinstrumenten.

\subsection{HR instrumenten}

Figuur 6.I geeft een overzicht van de mate waarin verschillende HR instrumenten die betrekking hebben op de arbeidsvoorwaarden en leeftijdbewust personeelsbeleid door de organisaties worden toegepast. Prestatiebeloning op teamniveau of op organisatieniveau, winstdeling, bonussen en demotie worden door IO\% of minder van de organisaties toegepast. Prestatiebeloning op individueel niveau (24\%) en gratificaties (28\%) komen daarentegen vaker voor. Bij beide HR instrumenten vormt de sector provincies en waterschappen een uitschieter. In deze sector past $66 \%$ van de werkgevers prestatiebeloning op individueel niveau toe, terwijl $37 \%$ bepaalde medewerkers gratificaties toekent. Gratificaties worden bij water, energie en nutsbedrijven ook relatief vaak toegekend (65\%). De meest voorkomende vormen van personeelsbeleid op het terrein van arbeidsvoorwaarden zijn spaarloonregelingen (84\%) en levensloopsparen $(66 \%)$. Ongeveer $37 \%$ van de bedrijven geeft aan dat zij op het terrein van de arbeidsvoorwaarden een leeftijdbewust of levensfasebewust personeelsbeleid voeren. ${ }^{37}$

In veel organisaties wordt gebruik gemaakt van Persoonlijke opleidings- en ontwikkelingsplannen (POP) (zie figuur 6.2). Ongeveer 54\% van de organisaties hanteert dergelijke plannen, maar dit percentage is beduidend lager bij het rijk $(30 \%)$, de bouw

36. B. Lokhorst (20II). Duurzame inzetbaarheid en langer doorwerken in de CAO.

37. In hoofdstuk 7 leggen wij de link tussen aspecten van het HR beleid van werkgevers en uitkomsten uit de enquête onder werknemers. 
(31\%), het wetenschappelijk onderwijs, onderzoek en wetenschapsbeleid (37\%) en de schoonmaak- en glazenwassersbedrijven (21\%). Daarnaast wordt coaching (39\%) en het bevorderen van de zelfstandigheid van werknemers (42\%) ook vaak toegepast. Afgezien van loopbaanplanning (toegepast door $23 \%$ van de werkgevers) worden HR instrumenten gericht op de mobiliteit van werknemers (functie- en taakroulatie, periodiek loopbaanadvies en het bevorderen van de externe mobiliteit) slechts weinig toegepast (door minder dan I5\% van de organisaties). Dit bevestigt het beeld dat naar voren komt uit eerder CAO onderzoek (Lokhorst 20II). Functie- en taakroulatie worden overigens het vaakst toegepast in het primair onderwijs ( $24 \%$ van de werkgevers).

\section{Figuur 6.1}

Mate waarin HR instrumenten op het terrein van de arbeidsvoorwaarden en leeftijdbewust personeelsbeleid worden toegepast (percentage vaak of altijd toegepast)

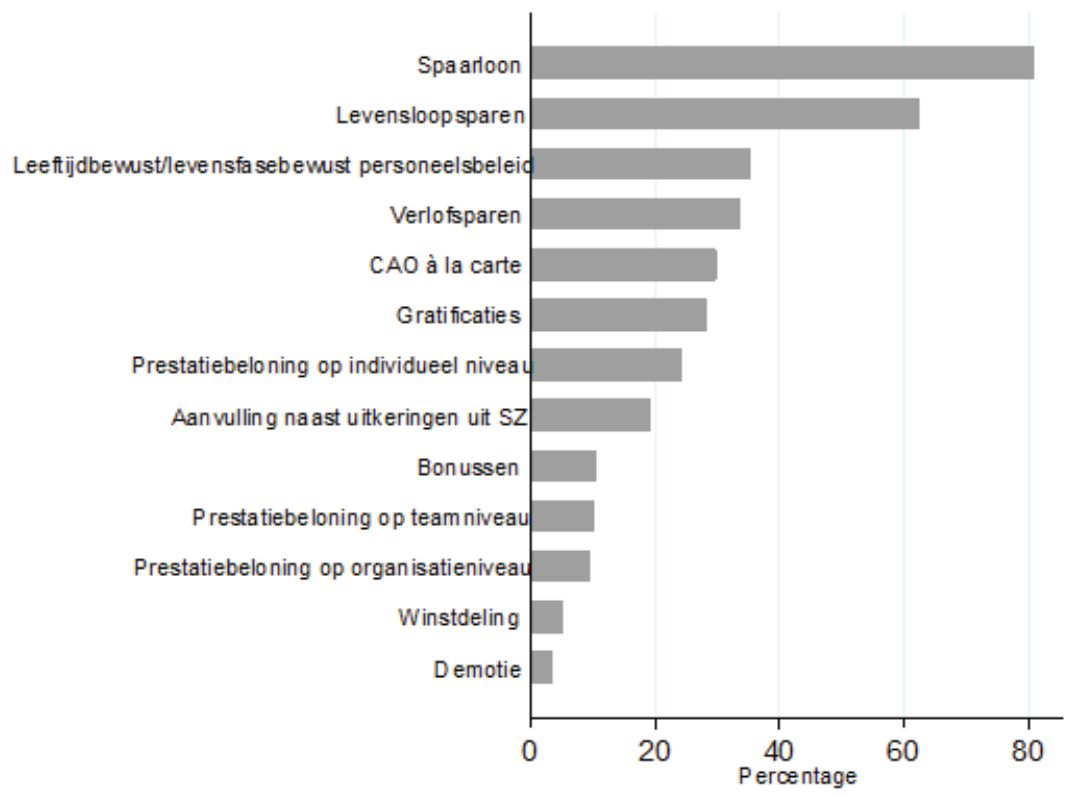

Als het gaat om HR instrumenten op het gebied van gezondheid en belastbaarheid blijkt dat ruim $73 \%$ van de organisatie een arbobeleid heeft (figuur 6.3). Daarnaast geeft ongeveer de helft van de organisaties aan dat zij HR instrumenten inzetten die gericht zijn op de aanpassing van het werk aan de belastbaarheid van de werknemers. Uit CAO onderzoek weten wij dat maar in een beperkt aantal CAO's het onderwerp van belastbaarheid expliciet een plek krijgt in de functioneringsgesprekken (Lokhorst 20II). Het personeelsbeleid lijkt op dit punt dus verder te reiken dan de CAO afspraken. Ondersteuning van de werknemers bij het zoeken naar ander werk bij te zware functies wordt door iets meer dan $40 \%$ van de organisaties gedaan. Vrijstelling 
van diensten (nachtdiensten, bereikbaarheidsdiensten, beschikbaarheidsdiensten, en overwerk) wordt minder vaak toegepast. Dit geldt overigens ook voor onderzoek naar werkvermogen en vitaliteit.

\section{Figuur 6.2}

Mate waarin HR instrumenten op gebied van loopbaanbegeleiding worden toegepast (percentage vaak of altijd toegepast)

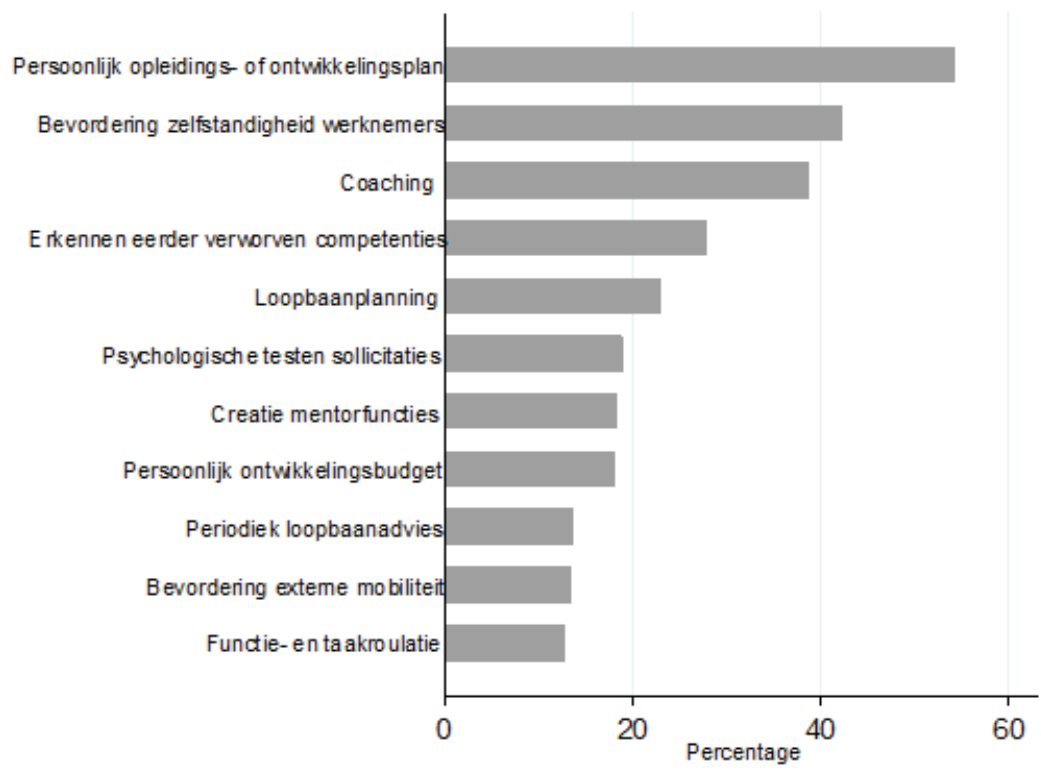




\section{Figuur 6.3}

Mate waarin HR instrumenten op gebied van gezondheid worden toegepast (percentage vaak of altijd toegepast)

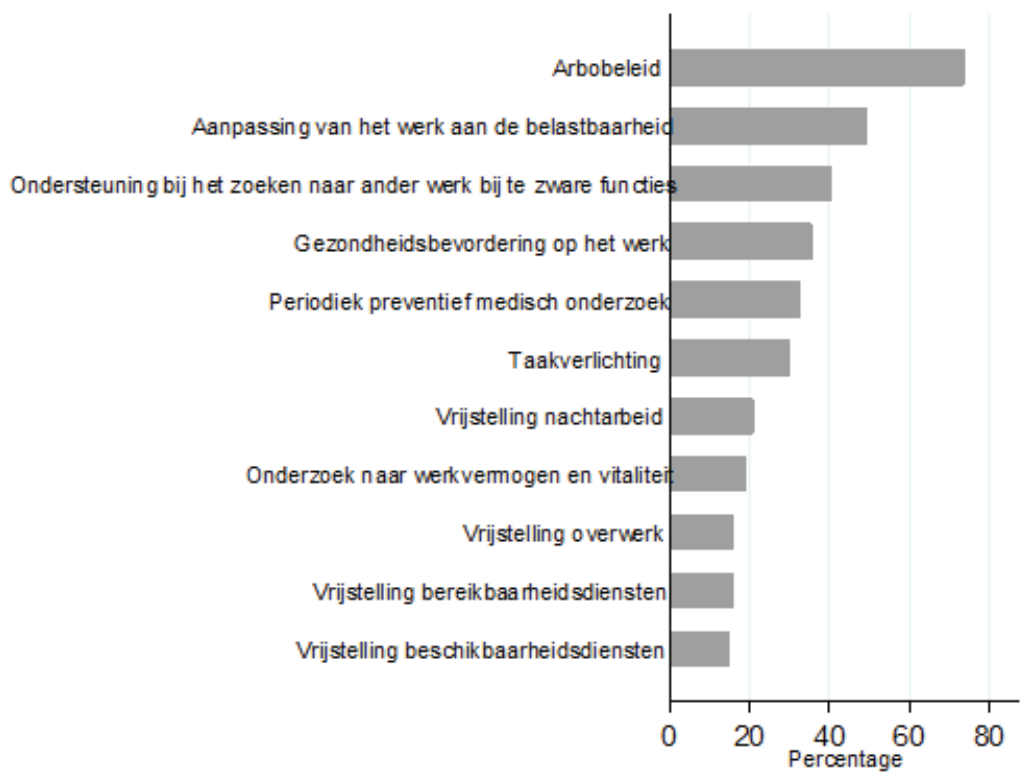

Figuur 6.4 laat zien welke vormen van flexibele werkarrangementen door de organisaties worden ingezet. De helft van de werkgevers kent flexibele begin- en eindtijden van de werkdag. Dit percentage is overigens hoger bij het rijk, de provincies en waterschappen en het hoger beroepsonderwijs en het wetenschappelijk onderwijs, onderzoek en wetenschapsbeleid. In de bouw, het primair en voortgezet onderwijs worden flexibele begin- en eindtijden van de werkdag nauwelijks toegepast. Er wordt ook veel in teamverband gewerkt (40\%). Daarbij is in $36 \%$ van de organisaties sprake van zelfverantwoordelijke teams. Verrassend is dat thuiswerken slechts bij $30 \%$ van de bedrijven mogelijk is. Overigens zijn ook hier het rijk, de provincies en waterschappen, het hoger beroepsonderwijs en het wetenschappelijk onderwijs, onderzoek en wetenschapsbeleid koploper, met ongeveer de helft van de werkgevers die thuiswerken toepast. Thuisweken is ook mogelijk bij ruim de helft van de bedrijven in de sectoren overige en vrijwillige toetreders. Flexibele en gecomprimeerde werkwerken worden toegepast door $27 \%$ van de organisaties. In de bouw, het primair en secundair onderwijs en de beroeps- en volwasseneneducatie komen deze vormen van flexibiliteit echter beduidend minder vaak voor. 


\section{Figuur 6.4}

Mate waarin HR instrumenten op gebied van flexibiliteit worden toegepast (percentage vaak of altijd toegepast)

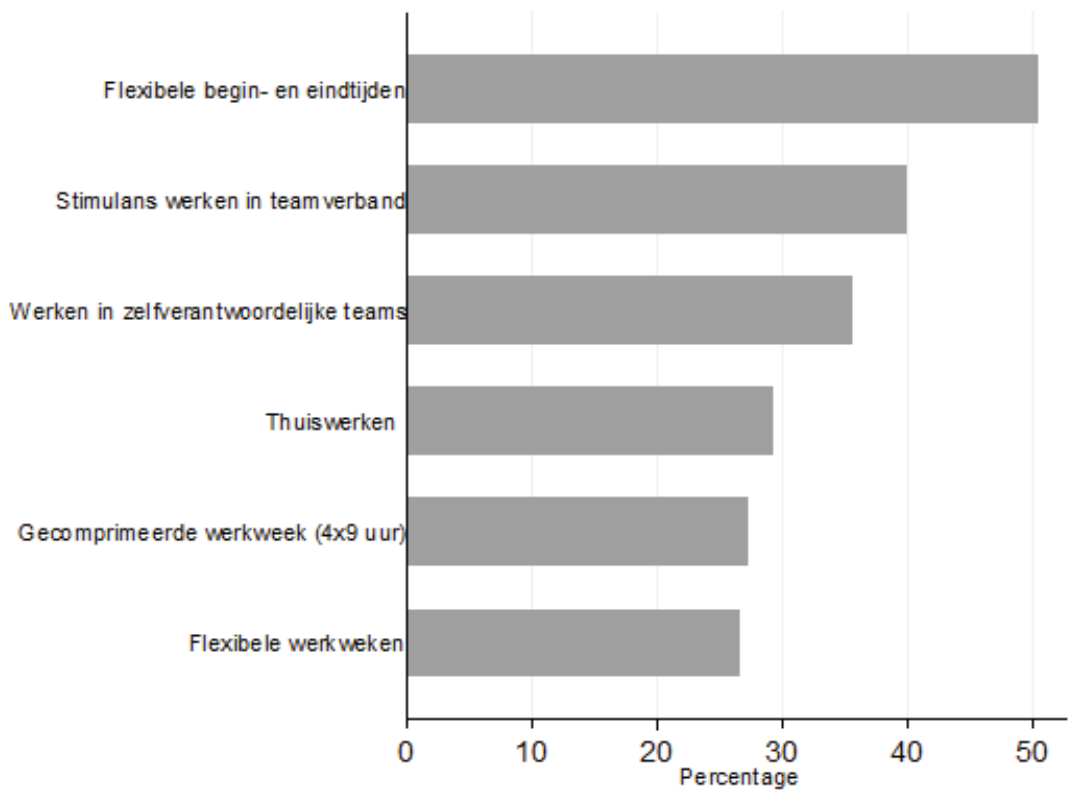

$\mathrm{Al}$ met al is $80 \%$ van de organisaties het eens met de stelling dat 'mijn organisatie zorgt voor hulp en ondersteuning als werknemers dat nodig hebben', terwijl ongeveer $77 \%$ het eens is met de stelling 'mijn organisatie is echt betrokken bij het welzijn van haar werknemers' en met de stelling 'mijn organisatie is altijd bereid om zich in te zetten voor haar werknemers'. 6I\% van de organisaties vindt dat de leiding van de organisatie een goed personeelsbeleid voert.

\subsection{HRM beleid gericht op oudere werknemers}

Oudere werknemers zijn kwetsbaar op de arbeidsmarkt. Hun kennis en vaardigheden zijn niet altijd up-to-date en eenmaal werkloos komen zij weer moeilijk aan werk. Uit de in hoofdstuk 5 (tabel 5.3) gepresenteerde analyses bleek ook dat jongere werknemers altijd de voorkeur genieten boven oudere werknemers. Uit eerder CAO onderzoek blijkt dat het onderwerp van inzetbaarheid en vitaliteit van oudere werknemers wel vaak op de agenda staat (Lokhorst 20II), maar de vraag is in hoeverre het HR beleid in organisaties in de praktijk voldoende gericht is op de oudere werknemers.

Het blijkt dat de ontwikkeling van een dergelijk beleid in veel organisaties stagneert. Slechts $28 \%$ van de bedrijven geeft aan dat ze in het afgelopen jaar zich meer zijn gaan inzetten om hun werknemers tot op een hogere leeftijd aan het werk te houden. Wel 
blijkt dat $69 \%$ van de organisaties het mogelijk maakt voor oudere werknemers om in deeltijd te gaan werken.

\section{Figuur 6.5}

Mate waarin HR instrumenten gericht oudere werknemers worden toegepast (percentage vaak of altijd toegepast)

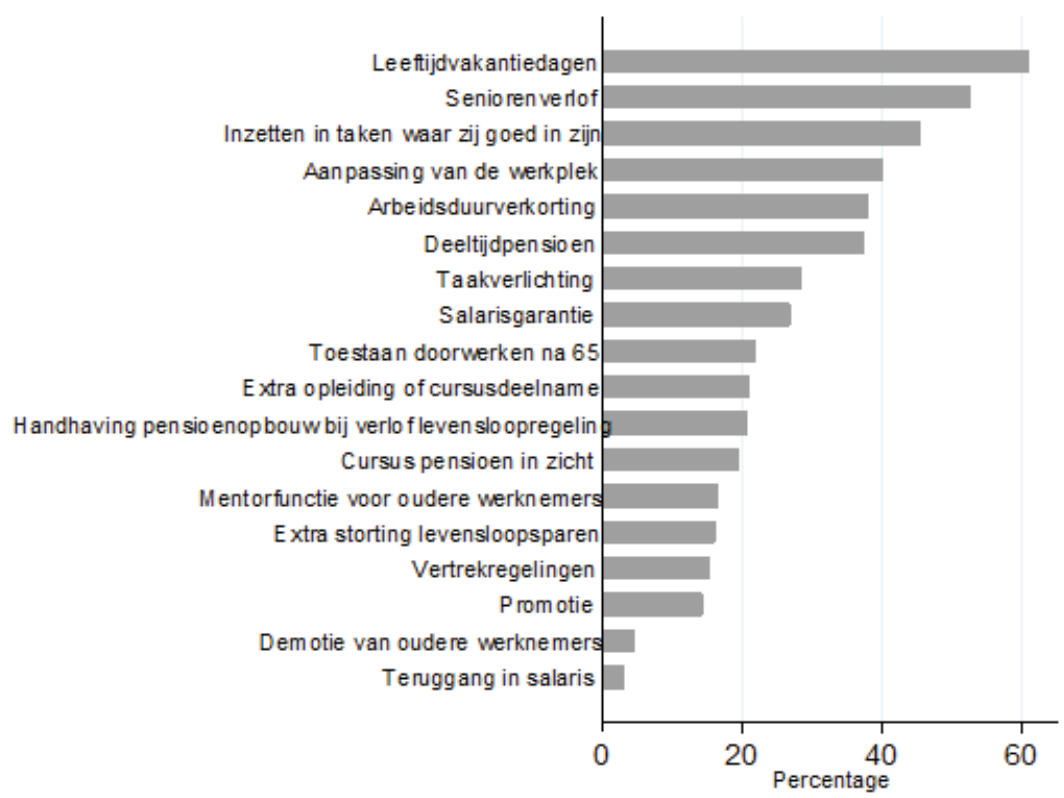

Figuur 6.5 laat zien welke HR instrumenten worden ingezet die specifiek gericht zijn op oudere werknemers. Maatregelen als demotie en teruggang in salaris worden slechts zeer zelden toegepast. De maatregelen die het vaakst worden toegepast zijn er vooral op gericht om de oudere werknemers te ontzien op het werk door middel van leeftijdvakantiedagen en seniorenverlof (dit komt overeen met de bevindingen van Lokhorst 20II). Naast dit ontziebeleid worden slechts enkele actieve maatregelen vaker toegepast, zoals het inzetten van oudere werknemers in taken waar zij goed in zijn $(45 \%)$ en het aanpassen van de werkplek (40\%).

Op basis van een factoranalyse zijn de op oudere medewerkers gerichte HR maatregelen in figuur 6.5 gegroepeerd naar het type beleid:

- Ontziebeleid: bijvoorbeeld leeftijd vakantiedagen en arbeidsduurverkorting;

- Beloningsprikkels: bijvoorbeeld promotie of demotie;

- Pensioenbeleid: bijvoorbeeld deeltijdpensioen en vertrekregelingen;

- Taakaanpassing en scholing: bijvoorbeeld inzetten in mentorfunctie of extra opleiding. 
Ontziebeleid wordt relatief vaak toegepast bij het rijk, de politie, het voortgezet onderwijs, het hoger beroepsonderwijs en het wetenschappelijk onderwijs, onderzoek en wetenschapsbeleid. De laatste drie sectoren zijn ook sectoren waar taakaanpassing en scholing met betrekking tot oudere werknemers relatief vaak wordt toegepast. Ontziebeleid wordt daarentegen significant minder vaak toegepast in het primair onderwijs en vrijwillige toetreders. Beloningsprikkels gericht op ouderen worden vaker gebruikt bij de politie en in universitaire medische centra. Het wordt significant minder vaak toegepast in het primair onderwijs.

Er zijn ook grote sectorale verschillen in het gebruikt van pensioenbeleid. Dergelijk beleid wordt vaker gebruikt bij de politie, in het hoger beroepsonderwijs, bij universitaire medische centra en water, energie en nutsbedrijven. Daarentegen wordt dergelijk beleid minder vaak toegepast in het primair onderwijs, in de bouw, bij woningcorporaties, bij vrijwillige toetreders en vooral de schoonmaak- en glazenwassersbedrijven.

\section{Tabel 6.1}

Sectorverschillen in specifiek op ouderen gerichte HR beleid

\begin{tabular}{|c|c|c|c|c|}
\hline & $\begin{array}{l}\text { Ontzie- } \\
\text { beleid }\end{array}$ & $\begin{array}{c}\text { Belonings- } \\
\text { prikkels }\end{array}$ & $\begin{array}{c}\text { Pensioen- } \\
\text { beleid }\end{array}$ & $\begin{array}{l}\text { Taakaan- } \\
\text { passing en } \\
\text { scholing }\end{array}$ \\
\hline Rijk & 0 & 0 & 0 & 0 \\
\hline Provincies en waterschappen & 0 & 0 & 0 & 0 \\
\hline Gemeenten & 0 & 0 & 0 & 0 \\
\hline Politie & + & + & + & 0 \\
\hline Primair onderwijs & - & - & - & 0 \\
\hline Voortgezet onderwijs & + & 0 & 0 & + \\
\hline Hoger beroepsonderwijs & + & 0 & + & + \\
\hline Wetenschappelijk onderwijs, onderzoek en wetenschapsbeleid & 0 & 0 & 0 & 0 \\
\hline Beroeps- en volwasseneneducatie & + & 0 & 0 & + \\
\hline Universitaire medische centra & 0 & + & + & 0 \\
\hline Water, energie en nutsbedrijven & + & 0 & + & 0 \\
\hline Vrijwillige toetreders & - & 0 & - & 0 \\
\hline Overige & 0 & 0 & 0 & 0 \\
\hline Bouw & 0 & 0 & - & 0 \\
\hline Woningcorporaties & 0 & 0 & - & 0 \\
\hline Schoonmaak- en glazenwassersbedrijven & - & - & - & - \\
\hline
\end{tabular}

Ter afsluiting van deze paragraaf bespreken wij kort een aantal stellingen met betrekking tot specifieke aandacht die ouderen krijgen binnen de organisatie (tabel 6.2). De helft van de organisaties is er (helemaal) mee eens met de stelling dat er tijdens functioneringsgesprekken gekeken wordt naar de gezondheidssituatie van oudere werk- 
nemers. Echter, slechts $8 \%$ van de organisaties geeft aan extra functie- of taakroulatie toe te passen op oudere werknemers om ze scherp te houden. Ook geeft slechts $14 \%$ van de organisaties er rekening mee te houden dat de taken van oudere werknemers niet routinematig of eentonig zijn. Op dit terrein lijkt het erop dat meer gedaan zou kunnen worden om oudere werknemers langer inzetbaar te houden op het werk. Zo heeft het onderzoek van Borghans e.a. (2OII) laten zien dat substantiële veranderingen in het werk positieve effecten op de kennisontwikkeling van oudere werknemers. ${ }^{38}$

Ondanks het feit dat langer werken sterk in de belangstelling staat, geeft toch nog $38 \%$ van de organisaties aan dat er in persoonlijke gesprekken informatie gegeven wordt over de mogelijkheden om met vervroegd pensioen te gaan. Dit zou er op kunnen duiden dat voor sommige organisaties de oudere werknemer als een kostenpost wordt ervaren. Het aanpassen van de taakbelasting van oudere werknemers is een onderwerp waar $28 \%$ van de organisaties zich mee bezig houdt. Dit is in lijn met de bevinding uit figuur 6.5 waar bleek dat taakverlichting van oudere werknemers wordt toegepast door iets minder dan $30 \%$ van de organisaties.

Tabel 6.2

Stellingen rond aandacht die oudere werknemers krijgen in de organisatie

$\begin{array}{lc} & \% \text { (helemaal) } \\ \text { mee eens }\end{array}$

\subsection{Scholing}

Tabel 6.3 laat zien dat de meeste bedrijven in 2011 een trainingsbudget hebben gereserveerd. In het beroeps- en volwassenenonderwijs en bij de vrijwillige toetreders, maar vooral ook in de bouw en schoonmaak- en glazenwassersbedrijven is dit echter minder vaak het geval. Gemiddeld genomen heeft $45 \%$ van de werknemers in 20 Io een interne bedrijfsopleiding of cursus gevolgd, terwijl $35 \%$ een externe opleiding of cursus heeft gevolgd. Interne cursussen komen vaker voor bij water, energie en nutsbedrijven, politie, het primair onderwijs en vooral bij woningcorporaties. Medewerkers bij het rijk, hoger beroepsonderwijs en wetenschappelijk onderwijs, onderzoek en wetenschapsbeleid en het beroeps- en volwassenenonderwijs volgen minder vaak interne

38. L. Borghans, D. Fouarge en A. de Grip (20II), Een leven lang leren in Nederland, ROA-R-20II/5, Maastricht. 
cursussen. In de schoonmaak- en glazenwassersbedrijven wordt weinig deelgenomen aan interne of extern cursussen. Externe cursussen komen daarentegen vaker voor bij woningcorporaties, water, energie en nutsbedrijven, het rijk, provincies en waterschappen en het primair onderwijs en minder vaak bij beroeps- en volwasseneneducatie en de politie.

Het mediane scholingsbudget voor het jaar $201 \mathrm{I}$ bedraagt $€ 30.000$ per organisatie, of te wel ongeveer $€ 430$ per werknemer. ${ }^{39}$ Hoewel er geen significante relatie is tussen de hoogte van het trainingsbudget per werknemer en de bedrijfsgrootte, blijkt wel dat het gemiddelde loon in het bedrijf samengaat met een hoger trainingsbudget per werknemer.

\section{Tabel 6.3}

Deelname aan interne of externe scholing, en aanwezigheid van specifiek trainingsbudget, naar sector

\begin{tabular}{|lccc|}
\hline & $\begin{array}{c}\text { Deelname interne } \\
\text { scholing }\end{array}$ & $\begin{array}{c}\text { Deelname externe } \\
\text { scholing }\end{array}$ & $\begin{array}{c}\text { Heeft budget } \\
\text { voor scholing }\end{array}$ \\
\hline Rijk & 33 & 37 & 100 \\
\hline Provincies en waterschappen & 41 & 37 & 94 \\
\hline Gemeenten & 43 & 32 & 94 \\
\hline Politie & 53 & 24 & 100 \\
\hline Primair onderwijs & 57 & 37 & 96 \\
\hline Voortgezet onderwijs & 39 & 35 & 99 \\
\hline Hoger beroepsonderwijs & 29 & 32 & 95 \\
\hline Wetenschappelijk onderwijs, onderzoek en wetenschapsbeleid & 35 & 32 & 89 \\
\hline Beroeps- en volwasseneneducatie & 34 & 25 & 84 \\
\hline Universitaire medische centra & 37 & 15 & 100 \\
\hline Water, energie en nutsbedrijven & 51 & 42 & 100 \\
\hline Vrijwillige toetreders & 43 & 34 & 80 \\
\hline Overige & 32 & 29 & 99 \\
\hline Bouw & 41 & 37 & 58 \\
\hline Woningcorporaties & 65 & 51 & 56 \\
\hline Schoonmaak- en glazenwassersbedrijven & 24 & 20 & 95 \\
\hline Totaal & 45 & 35 & 96 \\
\hline
\end{tabular}

De meeste gevolgde cursussen (tabel 6.4) hebben betrekking op de bedrijfshulpverlening $(73 \%)$ en vakspecifieke kennis $(72 \%)$. Daarnaast bieden veel bedrijven hun

39. Dit is exclusief de sectoren bouw, woningcorporaties en schoonmaak- en glazenwassersbedrijven waarvoor het aantal werkenden per bedrijf niet bekend is. Wij gaan uit van het mediaan omdat et gemiddelde gevoelig is extreme waarden. 
personeel cursussen aan rond coaching (43\%) en leidinggeven (44\%). Cursussen op het gebied van communicatie sluiten de top af.

\section{Tabel 6.4}

Kennis en vaardigheden waarop de cursussen die in 2010 gevolgd zijn waren gericht

\begin{tabular}{|c|c|}
\hline Bedrijfshulpverlening (BHV) & 73 \\
\hline Vakspecifieke kennis & 72 \\
\hline Leiding geven & 44 \\
\hline Coaching & 43 \\
\hline Duidelijk communiceren & 33 \\
\hline Sociale vaardigheden & 29 \\
\hline Veiligheid & 29 \\
\hline Omgaan met mensen & 28 \\
\hline Werken met computers & 28 \\
\hline Technische kennis & 27 \\
\hline Time management & 23 \\
\hline Administratieve vaardigheden & 22 \\
\hline Schrijven & 16 \\
\hline Mensen beïnvloeden of overtuigen & 15 \\
\hline Organiseren & 14 \\
\hline Algemene kennis & 13 \\
\hline Presenteren & 13 \\
\hline Informatie verzamelen en verwerken & 12 \\
\hline Stressbestendigheid & 9 \\
\hline Onderhandelen & 8 \\
\hline Cijfermatig inzicht & 7 \\
\hline Commercieel inzicht & 7 \\
\hline Analytisch denken & 5 \\
\hline Buitenlandse talen & 5 \\
\hline Creativiteit & 5 \\
\hline Flexibiliteit & 4 \\
\hline Besluitvaardigheid & 4 \\
\hline Fysieke conditie en kracht & 3 \\
\hline Nauwkeurigheid & 2 \\
\hline Doorzettingsvermogen & 1 \\
\hline Overige cursussen & 17 \\
\hline
\end{tabular}


Het gebruik van trainingsinstrumenten wordt in figuur 6.6 weergegeven. Daaruit valt af te lezen dat $8 \mathrm{I} \%$ van de organisaties vaak of altijd gebruik maakt van bij- en nascholing. Dit is overigens vaker het geval bij het primair en voortgezet onderwijs en bij de woningcorporaties (tabel 6.5). $75 \%$ kent een regeling voor tegemoetkoming in de studiekosten en $74 \%$ kent een regeling voor functiegerichte training. Slechts $29 \%$ biedt cursussen aan die gericht zijn op de gezondheid en vergroting van de belastbaarheid. Het rijk en het hoger beroepsonderwijs zijn op dit punt duidelijke uitschieters in positieve zin (tabel 6.5).

\section{Figuur 6.6}

Mate waarin organisatie scholingsinstrumenten gebruikt (\% vaak of altijd)

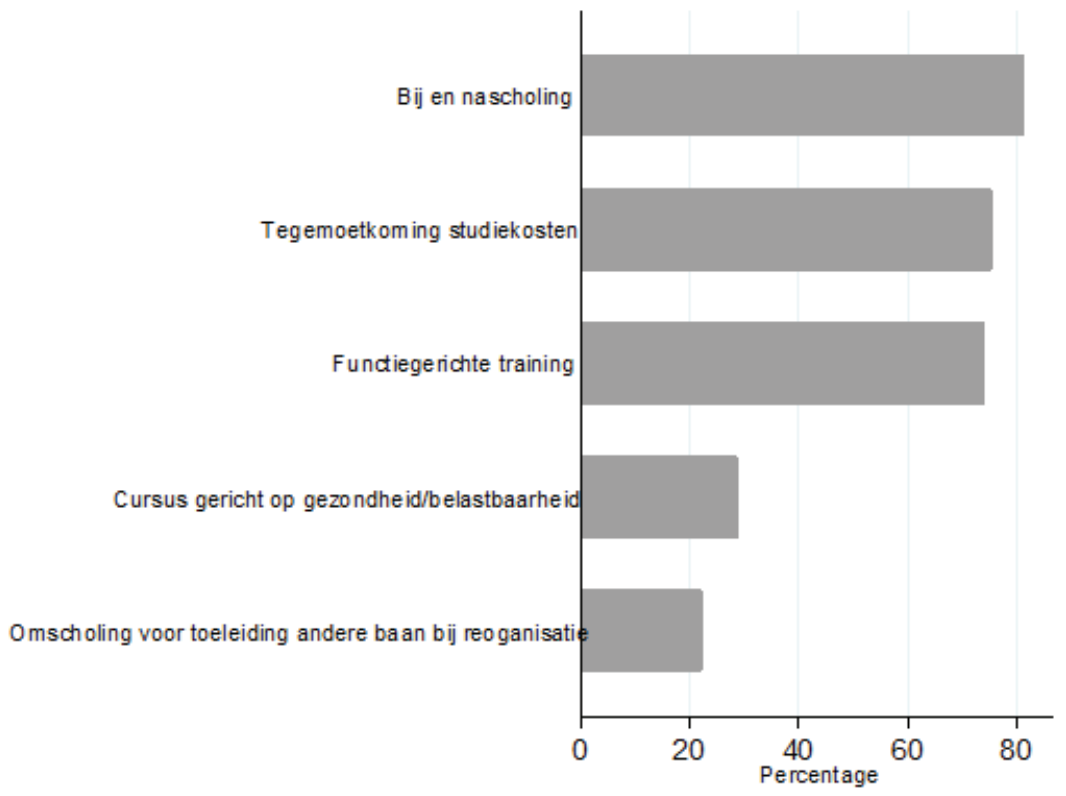

In het primair en voortgezet onderwijs en in de beroeps- en volwasseneneducatie wordt nauwelijks cursussen gericht op de gezondheid en vergroting van de belastbaarheid aangeboden. Iets meer dan een op de vijf organisaties (22\%) biedt omscholing voor toeleiding naar ander werk bij een reorganisatie. Daar valt echter bij op te merken dat niet alle organisatie te kampen krijgen met reorganisaties en dergelijke omscholing pas aangeboden wordt wanneer wel sprake is van een reorganisatie. 

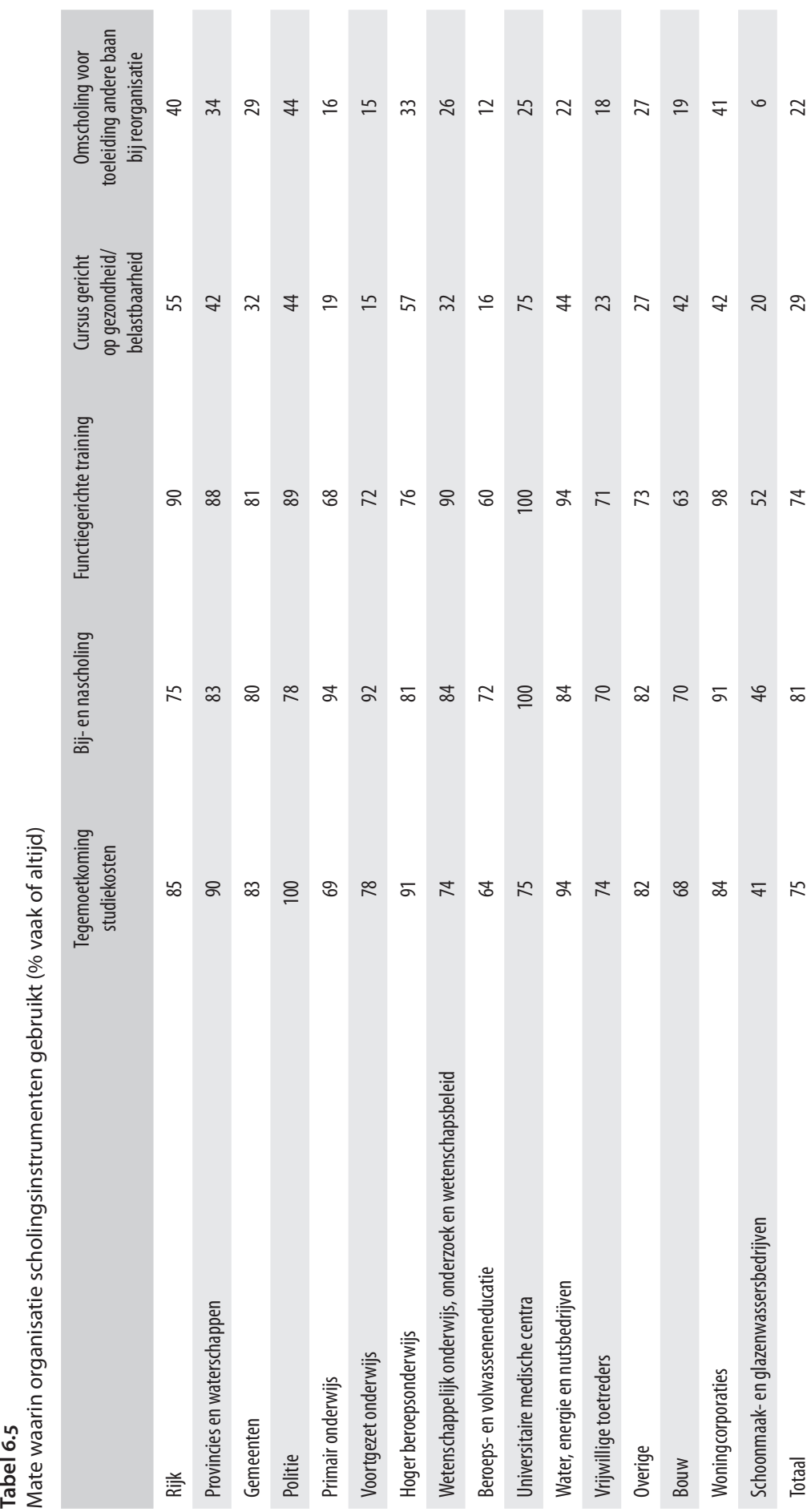


\section{Relatie tussen HR instrumenten en werknemersuitkomsten}

In de voorafgaande hoofdstukken is een overzicht gegeven van de werkinzet van werknemers, hun percepties van het gevoerde personeelsbeleid van hun werkgever, en de percepties van werknemers over de productiviteit van oudere werknemers. Daarop voortbouwend wordt in dit hoofdstuk in kaart gebracht in hoeverre de percepties over het personeelsbeleid van werkgevers en werknemers met elkaar overeenkomen en op welke aspecten van dit beleid de oordelen het meest uit elkaar lopen. Vervolgens wordt onderzocht welke HR instrumenten daadwerkelijk bijdragen aan de bevordering van de inzetbaarheid en de loopbaanontwikkeling van werknemers. Voor het beantwoorden van deze vraag wordt de werkgeversinformatie over het in hun organisatie gevoerde personeelsbeleid gerelateerd aan relevante uitkomstvariabelen op werknemersniveau.

\subsection{Vergelijking percepties van werkgevers en werknemers over personeelsbeleid}

Tabel 7.I laat zien hoe tevreden werknemers en werkgevers zijn over verschillende aspecten van het personeelsbeleid van de organisatie waarin zij werkzaam zijn. De eerste twee kolommen geven een overzicht van de tevredenheid over het personeelsbeleid van respectievelijk de werknemers en werkgevers. De kolommen 3 tot en met 5 laten zien in hoeverre werkgevers en werknemers op dit punt hetzelfde oordelen. Daarbij gaat het telkens om een vergelijking tussen het oordeel van de werknemers met die van hun eigen werkgever. ${ }^{40}$

Uit de eerste twee kolommen van de tabel valt op te maken dat werkgevers doorgaans positiever over het door hen gevoerde personeelsbeleid oordelen dan werknemers. Terwijl 58\% van de werkgevers aangeeft een goed personeelsbeleid te voeren, is dit percentage bij de werknemers een stuk lager (32\%). ${ }^{4 I}$ De grootste verschillen tussen het oordeel van werknemers en werkgevers doen zich voor bij het oordeel over de

40. Daartoe zijn de enquêtegegevens van de werknemers gekoppeld aan de enquêtegegevens van hun eigen werkgever.

4I. In hoofdstuk 6 (paragraaf 6.I) bleek dat 6r\% van de werkgevers aangeeft een goed personeelsbeleid te voeren. Het verschil met de hier gepresenteerde cijfers heeft te maken met het feit dat de analyses in dit hoofdstuk betrekking hebben op het gekoppeld werknemers-werkgeversbestand. 
betrokkenheid van de werkgevers bij het welzijn van werknemers, het personeelsbeleid in het algemeen, de bereidheid om zich in te zetten voor werknemers en het bieden van zorg en ondersteuning indien nodig. In alle gevallen zijn werkgevers positiever over het gevoerde personeelsbeleid dan hun werknemers. Wel moet worden geconcludeerd dat zowel werknemers (58\%) als werkgevers (75\%) over het bieden van zorg en ondersteuning als dat nodig is in het algemeen vrij positief zijn. Daarnaast valt op dat zowel werknemers als werkgevers vrij positief oordelen over de mogelijkheid om in deeltijd te (kunnen) gaan werken.

Tabel 7.1

Vergelijking van het oordeel van werkgevers en werknemers over het gevoerde personeelsbeleid (percentages)

\begin{tabular}{|c|c|c|c|c|c|}
\hline & \multicolumn{5}{|c|}{ Verschil in perceptie } \\
\hline & $\begin{array}{l}\text { Werknemers } \\
\text { die hiermee } \\
\text { instemmen }\end{array}$ & $\begin{array}{l}\text { Percentage } \\
\text { werkgevers } \\
\text { die hiermee } \\
\text { instemmen }\end{array}$ & $\begin{array}{c}\text { Geen } \\
\text { verschil }^{*}, *\end{array}$ & $\begin{array}{l}\text { Werkgever } \\
\text { positiever** }^{* *}\end{array}$ & $\begin{array}{l}\text { Werknemer } \\
\text { positiever** }^{* *}\end{array}$ \\
\hline Betrokken bij welzijn van werknemers & 48 & 71 & 52 & 34 & 14 \\
\hline Zorg voor hulp en ondersteuning indien nodig & 58 & 75 & 57 & 28 & 15 \\
\hline $\begin{array}{l}\text { Altijd bereid om zich in te zetten voor } \\
\text { werknemers }\end{array}$ & 41 & 67 & 50 & 37 & 13 \\
\hline $\begin{array}{l}\text { Inzet om werknemers langer aan het werk te } \\
\text { houden }\end{array}$ & 17 & 32 & 65 & 25 & 10 \\
\hline Bereid om taakbelasting aan te passen & 38 & 48 & 53 & 28 & 19 \\
\hline Mogelijk om in deeltijd te (kunnen) werken & 71 & 77 & 64 & 19 & 17 \\
\hline Voldoende waardering leidinggevenden & 56 & 44 & 50 & 17 & 33 \\
\hline $\begin{array}{l}\text { Alternatieve mogelijkheden om eerder uit te } \\
\text { treden }\end{array}$ & 14 & 17 & 73 & 15 & 12 \\
\hline $\begin{array}{l}\text { Goed personeelsbeleid } \\
\text { Werkgever en werknemer hebben dezel } \\
\text { * De laatste drie kolommen tellen op tot }\end{array}$ & $\begin{array}{l}32 \\
\text { oerceptie va } \\
\text { \%. }\end{array}$ & $\begin{array}{l}58 \\
\text { het gevoerc }\end{array}$ & $\begin{array}{c}51 \\
\text { personeels }\end{array}$ & 35 & 14 \\
\hline
\end{tabular}

Opmerkelijk is dat werknemers positiever oordelen dan werkgevers over de waardering die zij krijgen van hun directe leidinggevenden. Maar $44 \%$ van de werkgevers vindt dat er in hun organisatie voldoende waardering is van hun leidinggevenden voor hun werknemers, terwijl $56 \%$ van de werknemers hierover een positief oordeel heeft.

Kolom 3 geeft het percentage werknemers dat op het desbetreffende punt hetzelfde oordeelt als hun eigen werkgever. Kolom 4 geeft het percentage werknemers dat negatief oordeelt over het personeelsbeleid, terwijl hun werkgever hierover een positief oordeel heeft, terwijl kolom 5 aangeeft welk percentage werknemers positief oordeelt over het gevoerde personeelsbeleid terwijl hun eigen werkgever negatief oordeelt.

De in tabel 7.I gepresenteerde cijfers bevestigen het beeld dat er een substantiële mismatch bestaat tussen de percepties van werknemers en werkgevers over bepaalde 
facetten van het personeelsbeleid. Gemiddeld genomen geven werkgevers vaker een positiever oordeel dan hun werknemers. De helft van de werknemers is het eens met het oordeel dat hun werkgever gaf over de bereidheid van de leidinggevenden om zich in te zetten voor werknemers, terwijl $37 \%$ van de werknemers op dit punt negatiever oordeelt dan hun werkgever. Ook over het gevoerde personeelsbeleid in het algemeen $(5 \mathrm{I} \%)$ en de betrokkenheid van de werkgever bij het welzijn van werknemers (52\%) heeft slechts iets meer dan de helft van de werknemers hetzelfde oordeel als hun eigen werkgever, terwijl respectievelijk $34 \%$ en $35 \%$ van de werknemers op deze punten minder positief oordeelt dan hun eigen werkgever. Opmerkelijk is ook dat de mening van werknemers en hun werkgever over de waardering die directe leidinggevenden hebben voor hun medewerkers sterk uiteenloopt. Op dit punt is $33 \%$ van de werknemers positiever dan hun werkgever, terwijl I7\% negatiever oordeelt dan hun werkgever.

Werknemers en werkgevers geven het vaakst hetzelfde oordeel over de alternatieve mogelijkheden om eerder uit te treden. Het overgrote deel van zowel de werkgevers als werknemers geeft aan dat er geen of nauwelijks alternatieve mogelijkheden worden geboden om eerder uit te treden. Daarnaast is er maar een beperkte mismatch in het oordeel over de inzet om werknemers langer aan het werk te houden $(65 \%$ oordeelt hetzelfde). Slechts een kleine minderheid van de werknemers en werkgevers geeft aan dat er in het personeelsbeleid sprake is van extra inzet om werknemers langer aan het werk te houden. Dit suggereert dat werkgevers, ondanks de veranderingen in het pensioenstelsel, zowel in de perceptie van hun werknemers als volgens henzelf onvoldoende aandacht hebben voor een leeftijdsbewust personeelsbeleid dat er op gericht is om hun werknemers langer te laten werken. Daarentegen zijn werkgevers en werknemers wel beide positief over de mogelijk om in deeltijd te (kunnen) werken. 7I\% van de werknemers geeft aan dat zij deze mogelijkheid hebben. Volgens de werkgever ligt dit percentage nog wat hoger $(77 \%)$. Voor de werknemers die hierover een ander oordeel hebben dan hun werkgever geldt dat zij niet significant vaker een negatief oordeel geven.

Tabel 7.2 laat zien in welke mate werkgevers in de verschillende sectoren significant vaker positiever oordelen over het door hen gevoerde personeelsbeleid dan hun werknemers. Het blijkt dat er vooral sprake is van een mismatch in het oordeel tussen werkgevers en werknemers in de sectoren universitaire medische centra, het wetenschappelijk onderwijs, onderzoek en wetenschapsbeleid en politie. In deze sectoren wordt de ontevredenheid van werknemers over het gevoerde personeelsbeleid door hun werkgever fors onderschat. Specifiek zijn werkgevers in deze sectoren duidelijk positiever over hun betrokkenheid bij het welzijn van hun werknemers, de zorg voor hulp en ondersteuning wanneer dat nodig is, de bereidbaarheid om zich in te zetten voor werknemers en de inzet om werknemers langer aan het werk te houden. Opvallend is ook dat voor $49 \%$ van de werknemers in de sector wetenschappelijk onderwijs, onderzoek en wetenschapsbeleid de werkgever aangeeft dat er alternatieve 
mogelijkheden worden aangeboden om eerder uit te treden terwijl hun werknemers zelf aangeven dat dit niet het geval is.

Ook blijkt dat in de universitaire medische centra $(60 \%)$ en de sector wetenschappelijk onderwijs, onderzoek en wetenschapsbeleid (55\%) meer dan de helft van de werknemers minder positief is over het gevoerde personeelsbeleid dan hun werkgever. Bij de politie is dit eveneens vaak het geval $(43 \%)$. Daarentegen is het percentage werkgevers dat positiever oordeelt over het gevoerde personeelsbeleid relatief laag in de sectoren rijk en hoger beroepsonderwijs.

Uit tabellen 7.I en 7.2 blijkt dat het oordeel van werknemers en werkgevers over het gevoerde personeelsbeleid nogal uiteen kan lopen. Daar zijn verschillende mogelijke verklaringen voor. In de eerste plaats kan het zo zijn dat werkgevers of werknemers een andere perceptie hebben van de in hun organisatie gevoerde personeelsbeleid. In de tweede plaats is het mogelijk dat werkgevers een bepaald beleid voeren, maar dat het slechts een kleine doelgroep treft. In de derde plaats kan het zijn dat werknemers niet over adequate informatie beschikken over het door hun werkgever gevoerd beleid; zij weten bijvoorbeeld niet of een bepaald beleid wel of niet wordt gevoerd. Het kan zelfs zo zijn dat sommige werkgevers niet goed weten wat voor beleid er in hun organisatie wordt gevoerd. Dergelijke informatieproblemen kunnen verband houden met de grootte van de organisatie. 


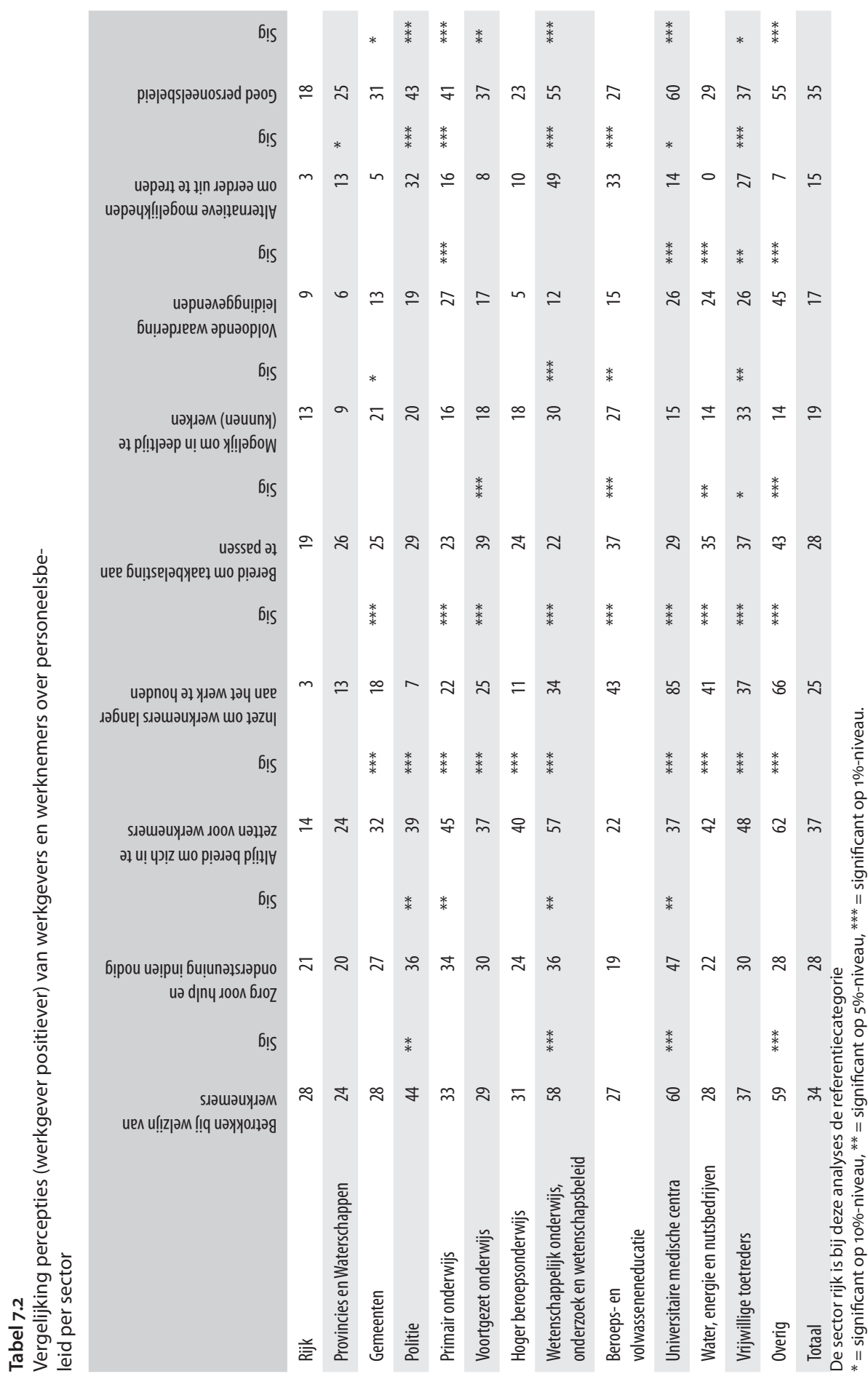




\subsection{Relatie tussen oordeel personeelsbeleid van de werkgever en pensioenverwachtingen}

Tabel 7.3 laat zien hoe het oordeel van werkgevers over het door hun gevoerde personeelsbeleid gerelateerd is aan de pensioenverwachtingen van hun werknemers. In overeenstemming met de resultaten in tabel 4.5 waarin de tevredenheid van werknemer werd gerelateerd aan de pensioenleeftijd en werkinzet van werknemers, vinden wij dat de tevredenheid over het personeelsbeleid in beperkte mate correleert met de pensioenverwachtingen. Alleen extra inzet om werknemers langer aan het werk te houden draagt bij tot een uitstel van het pensioen met twee maanden. Interessant is daarbij dat in tabel 4.5 geen significant effect op de verwachte pensioenleeftijd werd gevonden van de door de werknemer gepercipieerde inzet van de werkgever om hun langer in dienst te houden.

\section{Tabel 7.3}

Relatie tussen het oordeel van de werkgever over het gevoerde personeelsbeleid en de pensioenverwachtingen van werknemers (coëfficiënten uit OLS regressie)

\begin{tabular}{|c|c|c|c|}
\hline & $\begin{array}{l}\text { (1) } \\
\text { Verwachte pensioen } \\
\text { leeftijd }\end{array}$ & $\begin{array}{c}(2) \\
\text { Deeltijd } \\
\text { pensioen }\end{array}$ & $\begin{array}{c}\text { (3) } \\
\text { Levensloop }\end{array}$ \\
\hline \multicolumn{4}{|l|}{ Tevredenheid personeelsbeleid werkgever } \\
\hline Betrokken bij welzijn van werknemers & 0,145 & $-0,029$ & $-0,013$ \\
\hline Zorg voor hulp en ondersteuning indien nodig & 0,069 & 0,016 & 0,039 \\
\hline Altijd bereid om zich in te zetten voor werknemers & $-0,071$ & $-0,060^{*}$ & $-0,016$ \\
\hline Inzet om werknemers langer aan het werk te houden & $0,190^{* *}$ & 0,013 & $-0,024$ \\
\hline Bereid om taakbelasting aan te passen & 0,003 & 0,002 & 0,007 \\
\hline Mogelijk om in deeltijd te (kunnen) werken & $-0,072$ & 0,015 & 0,005 \\
\hline Voldoende waardering leidinggevenden & $-0,126$ & $-0,003$ & $0,037^{*}$ \\
\hline Alternatieve mogelijkheden om eerder uit te treden & $-0,051$ & 0,023 & $-0,005$ \\
\hline Goed personeelsbeleid & $-0,207$ & 0,025 & 0,009 \\
\hline \multicolumn{4}{|l|}{ Pensioen } \\
\hline Verwachte pensioenuitkering op 62 jarige leeftijd & $-0,017^{* * *}$ & 0,001 & 0,000 \\
\hline Aantal contributiejaren & $-0,023^{* *}$ & $0,003^{*}$ & $0,006^{* * *}$ \\
\hline Controle variabelen ${ }^{1)}$ & ja & ja & ja \\
\hline Constante term & $67,161^{* * *}$ & $0,672^{* *}$ & 0,052 \\
\hline $\begin{array}{l}\mathrm{N} \\
\text { Controle variabelen: geslacht, leeftijd, opleidir } \\
\text { activiteit. } \\
\text { = significant op } 10 \% \text {-niveau, }{ }^{*}=\text { significant o }\end{array}$ & $\begin{array}{l}1.036 \\
\text { veau, burgerlijke st } \\
\text {-niveau, }{ }^{* * *}=\text { signi }\end{array}$ & $\begin{array}{l}1.037 \\
\text { ezondheid, } \\
\text { op 1\%-nive }\end{array}$ & $\begin{array}{c}1.037 \\
\text { actor, sector }\end{array}$ \\
\hline
\end{tabular}

Opmerkelijk is verder dat de verwachte pensioenleeftijd van werknemers niet wordt beïnvloed door het oordeel van werkgevers over de mogelijkheid om in deeltijd te werken, de mate waarin de werkgever betrokken is bij het welzijn van werknemers en 
de bereidheid om de taakbelasting aan te passen. In tabel 4.5 bleek dat een positief werknemersoordeel over deze drie facetten van het personeelsbeleid wel gerelateerd is aan een hogere pensioenleeftijd. De divergentie in deze resultaten is waarschijnlijk het gevolg van de grote mismatch in het oordeel tussen werkgevers en werknemers en de structurele overschatting van de tevredenheid over het personeelsbeleid van medewerkers door werkgevers. Mogelijke oorzaken voor deze mismatch zijn in de vorige paragraaf aan bod gekomen.

\subsection{Relatie tussen oordeel van de werkgever over personeelsbeleid en de werkinzet van medewerkers}

Uit tabel 7.4 blijkt dat het oordeel van de werkgever over het gevoerde personeelsbeleid maar op enkele facetten van het personeelsbeleid is gerelateerd aan de werkinzet van werknemers.

\section{Tabel 7.4}

Relatie tussen het oordeel van de werkgever over het gevoerde personeelsbeleid en de werkinzet van medewerkers (coëfficiënten uit OLS regressie)

\begin{tabular}{|c|c|c|c|c|}
\hline & $\begin{array}{l}\text { (4) } \\
\text { Onbetaalde } \\
\text { overuren }\end{array}$ & $\begin{array}{c}\text { (5) } \\
\text { Aantal } \\
\text { ziektedagen }\end{array}$ & $\begin{array}{c}\text { (6) } \\
\text { Baan } \\
\text { tevredenheid }\end{array}$ & $\begin{array}{c}\text { (7) } \\
\text { Bevlogenheid }\end{array}$ \\
\hline \multicolumn{5}{|l|}{ Tevredenheid personeelsbeleid werkgever } \\
\hline Betrokken bij welzijn van werknemers & 0,042 & 0,850 & $-0,062$ & $-0,072$ \\
\hline Zorg voor hulp en ondersteuning indien nodig & $-0,080^{* *}$ & 0,627 & 0,100 & 0,033 \\
\hline Altijd bereid om zich in te zetten voor werknemers & 0,043 & $-2,692^{*}$ & 0,105 & 0,084 \\
\hline Inzet om werknemers langer aan het werk te houden & 0,013 & 0,716 & 0,041 & 0,023 \\
\hline Bereid om taakbelasting aan te passen & $-0,002$ & $-0,321$ & $-0,021$ & $-0,046$ \\
\hline Mogelijk om in deeltijd te (kunnen) werken & $-0,024$ & 0,160 & 0,005 & $-0,046$ \\
\hline Voldoende waardering leidinggevenden & 0,014 & 0,222 & $-0,073$ & $-0,043$ \\
\hline Alternatieve mogelijkheden om eerder uit te treden & 0,013 & $-1,401^{*}$ & $-0,028$ & 0,015 \\
\hline Goed personeelsbeleid & $-0,040$ & 0,750 & $-0,084$ & 0,068 \\
\hline \multicolumn{5}{|l|}{ Pensioen } \\
\hline Verwachte pensioenuitkering op 62 jarige leeftijd & 0,000 & $-0,026$ & $0,006^{*}$ & 0,002 \\
\hline Aantal contributiejaren & $-0,001$ & $-0,132$ & $-0,007$ & $-0,005$ \\
\hline Controle variabelen ${ }^{1)}$ & ja & ja & ja & ja \\
\hline Constante term & $-0,196$ & 12,212 & $7,400^{* * *}$ & $4,419^{* * *}$ \\
\hline $\begin{array}{l}\text { 1) Controle variabelen: geslacht, leeftijd, oplei } \\
\text { van activiteit } \\
{ }^{*}=\text { significant op } 10 \% \text {-niveau, }{ }^{* *}=\text { significant of }\end{array}$ & $\begin{array}{l}1.036 \\
\text { sniveau, bu } \\
\text {-niveau, *** }\end{array}$ & $\begin{array}{l}1.036 \\
\text { rlijke staat, }\end{array}$ & $\begin{array}{l}1.008 \\
\text { ondheid, dee } \\
\text { o-niveau. }\end{array}$ & $\begin{array}{l}1.024 \\
\text { ijdfactor, sector }\end{array}$ \\
\hline
\end{tabular}


Een hogere score op de zorg voor hulp en ondersteuning is negatief gecorreleerd met het aantal onbetaalde overuren. De mogelijkheid bestaat dat deze ondersteuning zich kenmerkt door een minder zware taakbelasting waardoor er minder overuren kunnen worden gemaakt. De bereidheid om zich in te zetten voor werknemers en de inzet van alternatieve mogelijkheden om eerder uit te treden reduceert het aantal ziektedagen. Er is daarentegen geen significante relatie tussen de tevredenheid over de verschillende facetten van het personeelsbeleid van werkgevers en de baantevredenheid en bevlogenheid van werknemers. Dit is opvallend omdat in tabel 4.5 wel significante verbanden werden gevonden tussen deze twee laatst genoemde variabelen en het hebben van een hoger gevoel van waardering, een beter loopbaanperspectief, de mogelijkheid om in deeltijd te werken, een goed oordeel over het personeelsbeleid en de door de werknemer gepercipieerde bereidheid van werkgevers om zich in te zetten voor hun medewerkers. Dit duidt erop dat de grote mismatch in het oordeel tussen werkgevers en werknemers en de structurele overschatting van de tevredenheid over het personeelsbeleid van medewerkers door werkgevers mogelijk een demotiverend werking zouden kunnen hebben.

\subsection{Relatie tussen de ingezette HR instrumenten volgens de werkgever en pensioenverwachtingen}

Tabel 7.5 laat zien wat het effect is van de door de organisatie ingezette HR instrumenten (volgens de werkgever) op de pensioenverwachtingen van de werknemers. Door middel van factoranalyses onderscheiden we zeven facetten van het personeelsbeleid:

- Gesprekscycli: bijvoorbeeld het houden van functionerings-, ontwikkel- of beoordelingsgesprekken en werkoverleg.

- Scholing: bijvoorbeeld bij- en na scholing, tegemoetkoming studiekosten of functiegerichte training.

- Loopbaanontwikkeling: bijvoorbeeld loopbaanplanning, periodiek loopbaanadvies, coaching, persoonlijk opleidings- of ontwikkelingsplan, bevorderen externe mobiliteit.

- Gezondheid en werkbelasting: bijvoorbeeld aanpassing van werk aan de belastbaarheid, gezondheidsbevordering op het werk, taakverlichting.

- Vrijstelling onregelmatig werk: bijvoorbeeld vrijstelling overwerk, vrijstelling van bereikbaarheids- en beschikbaarheidsdiensten en vrijstelling nachtarbeid.

- Flexibiliteit: bijvoorbeeld flexibele werktijden, thuiswerken, flexibele werkweken en stimulans werken in teamverband.

- Arbeidsvoorwaarden: bijvoorbeeld leeftijdsbewust of levensfasebewust personeelsbeleid, CAO à la carte, bonussen, spaarloon en verlofsparen.

Uit de analyses blijkt dat de door de organisatie ingezette HR instrumenten nauwelijks invloed hebben op de pensioenverwachtingen van de werknemers. Er zijn echter enkele uitzonderingen. Zo wordt de verwachte pensioenleeftijd negatief beïnvloed 
door het gevoerde scholingsbeleid. Daarbij is het echter opmerkelijk dat er sprake is van een negatieve relatie, wat impliceert dat werknemers die werkzaam zijn in een organisatie met een duidelijk scholingsbeleid ongeveer 2 maanden eerder met pensioen denken te gaan. Deze relatie wordt primair veroorzaakt door bij- en nascholing die wordt geboden en niet door functiegerichte trainingen of een tegemoetkoming in studiekosten. De mogelijkheid bestaat derhalve dat de hier waargenomen relatie tussen het scholingsbeleid en de pensioneringsleeftijd wordt veroorzaakt door de mate waarin kennis en vaardigheden depreciëren binnen organisaties, waarbij zowel het scholingsbeleid als de lagere verwachte pensioenleeftijd reacties zijn op deze depreciatie van menselijk kapitaal.

\section{Tabel 7.5}

Relatie tussen het volgens de werkgever gevoerde personeelsbeleid en de pensioenverwachtingen van werknemers (coëfficiënten uit OLS regressie)

\begin{tabular}{|c|c|c|c|}
\hline & $\begin{array}{c}\text { (1) } \\
\text { Verwachte pensioen } \\
\text { leeftijd }\end{array}$ & $\begin{array}{c}(2) \\
\text { Deeltijd } \\
\text { pensioen }\end{array}$ & $\begin{array}{c}\text { (3) } \\
\text { Levensloop }\end{array}$ \\
\hline \multicolumn{4}{|l|}{ Personeelsbeleid } \\
\hline Gesprekscycli & 0,044 & $0,039^{*}$ & 0,002 \\
\hline Scholing & $-0,176^{*}$ & $-0,023$ & $-0,013$ \\
\hline Loopbaanontwikkeling & 0,061 & $0,039^{*}$ & 0,012 \\
\hline Gezondheid en werkbelasting & $-0,073$ & 0,014 & $-0,005$ \\
\hline Vrijstelling overwerk & 0,023 & $-0,042^{*}$ & $-0,005$ \\
\hline Flexibiliteit & $-0,057$ & $-0,043$ & 0,015 \\
\hline Arbeidsvoorwaarden & $-0,008$ & $-0,019$ & 0,027 \\
\hline \multicolumn{4}{|l|}{ Pensioen } \\
\hline Verwachte pensioenuitkering op 62 jarige leeftijd & $-0,021^{* * *}$ & 0,000 & 0,000 \\
\hline Aantal contributiejaren & $-0,028^{* *}$ & $0,004^{*}$ & $0,004^{* *}$ \\
\hline Controle variabelen 1 ) & ja & ja & ja \\
\hline Constante term & $66,129^{* * *}$ & $0,885^{* * *}$ & 0,022 \\
\hline \multicolumn{4}{|c|}{$\begin{array}{l}\text { Controle variabelen: geslacht, leeftijd, opleidingsniveau, burgerlijke staat, gezondheid, deeltijdfactor, sector } \\
\text { van activiteit. } \\
=\text { significant op } 10 \% \text {-niveau, }{ }^{* *}=\text { significant op } 5 \% \text {-niveau, }{ }^{* * *}=\text { significant op } 1 \% \text {-niveau. }\end{array}$} \\
\hline
\end{tabular}

De kans om met deeltijdpensioen te gaan is gerelateerd aan verschillende facetten van het personeelsbeleid. Het wordt positief beïnvloed door het hanteren van gesprekscycli en beleid gericht op loopbaanontwikkeling en negatief beïnvloed door beleid dat gericht is op het vrijstellen van overwerk. Bij de gesprekscycli dragen vooral functioneringsgesprekken positief bij aan de kans om met deeltijdpensioen te gaan. Dit duidt erop dat functioneringsgesprekken een goede gelegenheid bieden om de mogelijkheden om met deeltijdpensioen te gaan te bespreken. Bij het beleid gericht op loopbaanontwikkeling blijkt vooral de functie- en taakroulatie de kans om met 
Anderzijds is de baantevredenheid en de bevlogenheid van medewerkers negatief gerelateerd aan het voeren van een personeelsbeleid dat gericht is op de gezondheid en werkbelasting van werknemers. Hierbij speelt waarschijnlijk mee dat dit beleid waarschijnlijk het gevolg is van een te hoge werkbelasting en werkzaamheden binnen de organisatie die de gezondheid van werknemers aantasten. In zoverre is het dus waarschijnlijk dat niet het beleid een negatieve invloed heeft op de baantevredenheid en de bevlogenheid, maar eerder de aard van de werkzaamheden die binnen de organisatie worden uitgevoerd.

Samenvattend kan op basis van deze analyses worden geconstateerd dat, met uitzondering van het effect van het beleid gericht op loopbaanontwikkeling op het aantal ziektedagen, het door werkgevers gevoerde personeelsbeleid niet lijkt bij te dragen aan de werkinzet van werknemers.

\subsection{Relatie tussen het volgens de werkgever gevoerde ouderenbeleid op de pensioenverwachtingen}

Oudere werknemers zijn kwetsbaar op de arbeidsmarkt. Bovendien kunnen zij te kampen hebben met een veroudering van hun kennis en vaardigheden en eenmaal werkloos komen zij weer moeilijk weer aan werk. Uit de in tabel 5.3 gepresenteerde analyses bleek dat jongere medewerkers bij het invullen van een vacature altijd de voorkeur genieten boven oudere arbeidskrachten. Dit roept de vraag op in hoeverre het personeelsbeleid in organisaties voldoende gericht is op de oudere werknemers en in hoeverre het HR beleid succesvol is om ouderen te stimuleren om langer door te werken.

Tabel 7.7 laat zien in hoeverre de door de werkgever ingezette HR instrumenten die specifiek gericht zijn op oudere werknemers van invloed zijn op de pensioenverwachtingen. Op dezelfde wijze als in paragraaf 6.2 zijn de op oudere medewerkers gerichte HR instrumenten gegroepeerd naar het type beleid:

- Ontziebeleid: bijvoorbeeld leeftijdsvakantiedagen, arbeidsduurverkorting en seniorenverlof.

- Beloningsprikkels: bijvoorbeeld demotie, promotie en teruggang salaris.

- Pensioenbeleid: bijvoorbeeld deeltijdpensioen, vertrekregeling en extra storting in de levensloopregeling.

- Taakaanpassing en scholing: het inzetten van werknemers in taken waar zij goed in zijn, aanpassing van de werkplek, taakverlichting en extra opleidingen.

Uit de tabel blijkt dat het volgens de werkgever gevoerde ouderenbeleid vrijwel niet gerelateerd is aan de pensioenverwachtingen van de werknemers. De richting van de effecten van de vier facetten van het ouderenbeleid is weliswaar telkens zoals men zou kunnen verwachten. Zo is taakaanpassing bijvoorbeeld gerelateerd aan een hogere 
verwachte pensioenleeftijd), maar in de meeste gevallen zijn de effecten niet significant. Alleen beloningsprikkels blijken significant gecorreleerd te zijn met de kans om met deeltijdpensioen te gaan. Ook blijkt dat medewerkers van organisaties die veel doen aan taakaanpassing en scholing een 8\%-punt hogere kans hebben om te participeren in een levensloopregeling.

Tabel 7.7

Relatie tussen het volgens de werkgever gevoerde ouderenbeleid en de pensioenverwachtingen van werknemers (coëfficiënten uit OLS regressie)

\begin{tabular}{|c|c|c|c|}
\hline & $\begin{array}{l}\text { (1) } \\
\text { Verwachte pensioen } \\
\text { leeftijd }\end{array}$ & $\begin{array}{l}(2) \\
\text { Deeltijd } \\
\text { pensioen }\end{array}$ & $\begin{array}{c}\text { (3) } \\
\text { Levensloop }\end{array}$ \\
\hline \multicolumn{4}{|l|}{ Ouderenbeleid } \\
\hline Ontziebeleid & $-0,313$ & 0,075 & $-0,093$ \\
\hline Beloningsprikkels & 0,201 & $0,086^{* *}$ & 0,018 \\
\hline Pensioenbeleid & $-0,327$ & $-0,055$ & $-0,034$ \\
\hline Taakaanpassing en scholing & 0,405 & $-0,070$ & $0,084^{*}$ \\
\hline \multicolumn{4}{|l|}{ Pensioen } \\
\hline Verwachte pensioenuitkering op 62 jarige leeftijd & $-0,017^{* * *}$ & 0,001 & 0,000 \\
\hline Aantal contributiejaren & $-0,024^{* * *}$ & $0,004^{* *}$ & $0,005^{* * *}$ \\
\hline Controle variabelen ${ }^{1)}$ & ja & ja & ja \\
\hline Constante term & $65,650^{* * *}$ & $0,814^{* * *}$ & 0,177 \\
\hline \multicolumn{4}{|c|}{$\begin{array}{l}\text { Controle variabelen: geslacht, leeftijd, opleidingsniveau, burgerlijke staat, gezondheid, deeltijdfactor, sector } \\
\text { van activiteit. } \\
=\text { significant op } 10 \% \text {-niveau, }{ }^{* *}=\text { significant op } 5 \% \text {-niveau, }{ }^{* *}=\text { significant op } 1 \% \text {-niveau. }\end{array}$} \\
\hline
\end{tabular}

\subsection{Relatie tussen het volgens de werkgever gevoerde ouderenbeleid en de werkinzet}

Tabel 7.8 laat zien in hoeverre het volgens de werkgever gevoerde ouderenbeleid gerelateerd is aan de inzet van werknemers. Ook hier blijkt dat het ouderenbeleid slechts in zeer beperkte mate gerelateerd is aan de werkinzet van werknemers.

Er is geen enkele significante relatie tussen de vier onderscheiden facetten van het ouderenbeleid en het aantal ziektedagen, de baantevredenheid en de bevlogenheid van de medewerkers in de organisatie. Wij vinden alleen een relatie tussen het bieden van beloningsprikkels en de kans om onbetaalde overuren te maken. Het hanteren van beloningsprikkels verhoogt de kans op onbetaalde overuren met 6,4\%-punt. Het is aannemelijk dat hier sprake is van een causaal verband, waarbij dergelijke prikkels werknemers stimuleren om meer in hun eigen tijd te werken, om te voorkomen dat 
zij te maken krijgen met een teruggang in hun salaris. Analyses op uitsluitend oudere werknemers tussen de leeftijd van 55 en 64 jaar leveren hetzelfde beeld op.

\section{Tabel 7.8}

Relatie tussen het volgens de werkgever gevoerde ouderenbeleid en de werkinzet (coëfficiënten uit OLS regressie)







\section{Conclusie}

\subsection{Samenvatting}

De situatie rond de arbeidsmarktuittrede van oudere werknemers is sinds een aantal jaren drastisch aan het veranderen. De financiële crisis en de lage rente hebben een grote impact gehad op de dekkingsgraden van de pensioenfondsen, terwijl de vergrijzing en ontgroening van de Nederlandse samenleving voortschrijdt. Daarom zijn er in de afgelopen decennia diverse veranderingen doorgevoerd in de sfeer van de werknemersverzekeringen, VUT en prepensioen en de loon- en inkomstenbelasting om het langer doorwerken te stimuleren. Het pensioenakkoord omvat de meest recente plannen, waarbij de ingangsleeftijd van de AOW in 2020 wordt verhoogd van 65 naar 66 jaar en daarna wordt gerelateerd aan de levensverwachting van de gepensioneerden.

Werknemers zullen zich daarom moeten instellen op een verlenging van hun loopbaan en zich moeten afvragen hoe ze dat op een plezierige, gezonde en productieve wijze kunnen doen bij hun huidige of een andere werkgever. Werkgevers moeten zich instellen op een situatie waarin er meer 55-plussers aan het werk zijn en er door de introductie van meer flexibele pensioenregelingen ook een grotere variatie komt in leeftijd waarop mensen met pensioen gaan. De vraag is daarbij hoe zij uiteenlopende groepen werknemers kunnen helpen om binnen het bedrijf gemotiveerd, gezond en productief aan het werk te blijven, dan wel naar ander werk toe kunnen leiden? Deze rol van de werkgever is tot op heden in het onderzoek met betrekking tot de arbeidsmarkt van ouderen sterk onderbelicht gebleven.

In dit rapport is verslag gedaan van de belangrijkste uitkomsten van het onderzoek dat wij gedaan hebben in I4 specifieke overheids- en onderwijs sectoren, de bouwsector en de woningcorporaties.. Voor het onderzoek is gebruik gemaakt van twee datasets, waarbij de eerste dataset betrekking heeft op de eerste enquête van een nieuw werkgevers-werknemerspanel voor de overheid- en het onderwijs, de bouwsector en de woningcorporaties. De eerste dataset bestaat uit een combinatie van surveydata met administratieve data en is gebaseerd op een enquête die gehouden is onder een representatieve steekproef van werknemers in de leeftijd van 35 tot 65 jaar, en een werkgeversenquête onder werkgevers. De tweede dataset maakte het mogelijk om het causale effect te analyseren van de afschaffing van de FPU regeling en de invoering van 
het ABP Keuzepensioen in 2006 op de pensioenverwachtingen, met als bijkomend voordeel dat de data voor dezelfde personen beschikbaar zijn in vijf opeenvolgende jaren waardoor eveneens gemonitord kan worden hoe individuele medewerkers over een aantal jaren hun pensioen plannen.

\section{Pensioenverwachtingen}

Vanwege de achtereenvolgende veranderingen in de pensioenrechten van werkenden die de afgelopen twee decennia zijn doorgevoerd, hebben wij eerst onderzocht in hoeverre werknemers in staat zijn om hun pensioenrechten en mogelijke uittredeleeftijd correct in te schatten. Uit deze analyses blijkt dat werknemers verwachtingen hebben ten aanzien van de hoogte van hun pensioenuitkering die niet stroken met het pensioen dat zij later zullen ontvangen. Dit geldt specifiek voor jongere werknemers in de sectoren overheid en onderwijs, die een hoger pensioen verwachten te ontvangen dan de oudere werknemers. ${ }^{42}$ Dit duidt er op dat het pensioenbewustzijn bij jongere cohorten werknemers in deze sectoren nog onvoldoende is ontwikkeld. Echter, ook het pensioenbewustzijn in de bouw en woningcorporaties is onvoldoende.

De hoge verwachtingen ten aanzien van hun pensioen vertaalt zich in een lagere verwachte pensioenleeftijd onder werknemers in de bouw. Werknemers in de bouw denken gemiddeld genomen op 63-jarige leeftijd met werken te stoppen. Problematisch is daarbij dat jongere werknemers in deze sector niet significant later met pensioen denken te gaan dan de oudere. Daarentegen verwachten werknemers van de overheid, het onderwijs of de woningcorporaties gemiddeld genomen op 64 jarige leeftijd volledig te zullen stoppen met werken, terwijl jongere medewerkers in deze sectoren wel later denken uit te treden dan de ouderen.

De hervormingen van het pensioenstelsel hebben er toe geleid dat volledige arbeidsmarktuittrede op relatief jongere leeftijd steeds duurder wordt. Ook hebben werknemers veel grotere keuzemogelijkheden gekregen in de leeftijd waarop ze met pensioen willen gaan. Daarbij kan deeltijdpensioen een aantrekkelijke optie zijn om alsnog gedeeltelijk een vervroegde arbeidsmarktuittrede te realiseren. Het blijkt dat jongere werknemers inderdaad vaker denken van deeltijdpensionering gebruik te gaan maken. Ook verwachten zij op jongere leeftijd gebruik te gaan maken van deeltijdpensioen dan oudere cohorten. Dit duidt er op dat deeltijdpensionering inderdaad wordt zien als een alternatieve route om alsnog gedeeltelijk vervroegd uit te treden. Opmerkelijk is echter dat jongeren verwachten slechts twee maanden later definitief te stoppen met werken dan de huidige 55-plussers. Dit roept de vraag op of jongeren niet te optimistisch zijn over de duur van de periode waarin zij deeltijdpensioen zullen opnemen.

De hoge verwachtingen van jongeren ten aanzien van hun pensioen zorgt er voor dat zij nauwelijks anticiperen op het feit dat zij lagere pensioenrechten hebben. Terwijl

42. Zie tabel B.4 in de bijlage voor een uitbreid overzicht van de scores van alle sectoren. 
de versoberingen van de pensioenrechten in de eerste en tweede pijler van het pensioensysteem vooral jongere werknemers zouden moeten stimuleren om hun pensioen individueel aan te vullen door middel van producten die onder de derde pijler van het pensioenstelsel vallen, blijkt dat deze groep juist significant minder vaak investeert in hun pensioen.

Analyses laten verder zien dat een tekortschietende financiële deskundigheid een belangrijke oorzaak is van te optimistische verwachtingen. Werknemers die financieel kundig zijn denken vier maanden langer door te werken en sparen meer voor hun pensioen.

\section{Anticiperen op langer doorwerken}

In dit rapport is eveneens ingegaan op de effecten van de afschaffing van de FPU in de ABP-regeling en de geplande verhoging van de AOW leeftijd op de verwachtingen die werknemers van hun pensioenuitkering en pensioenleeftijd hebben. Het blijkt dat de afschaffing van de FPU een sterk effect heeft gehad op de verwachtingen die werknemers met versoberde pensioenrechten van hun pensioen hebben. Het verschil in de verwachte pensioenuitkering tussen werknemers met versoberde en de werknemers die nog de oude pensioenrechten hebben komt goed overeenkomt met het feitelijke verschil in pensioenrechten. Daarentegen is de financiële prikkel die uitgaat van de afschaffing van het FPU op de verwachte pensioenleeftijd op de langere termijn minder groot dan direct na de herziening van het pensioenstelsel. Opmerkelijk is ook dat het effect van de financiële crisis, die zich eind 2008 manifesteerde, op de verwachte pensioenuitkering en uittredeleeftijd zeer groot is. Dit effect blijkt zelfs groter te zijn dan het effect van de afschaffing van de FPU regeling.

In het kader van het onlangs afgesloten pensioenakkoord zullen werknemers die geboren zijn in 1955 of later moeten doorwerken tot 66 jaar en degenen die geboren zijn in 1960 of later naar alle waarschijnlijkheid tot 67 jaar. Uit onze analyses blijkt dat werknemers die geboren zijn in de jaren I955-1959 vier maanden later met pensioen denken te gaan. Van degenen die geboren zijn in 1954 denkt $45,6 \%$ met 65 jaar met pensioen te gaan, terwijl van degenen die geboren zijn in 1955 nog maar $26,2 \%$ verwacht op die leeftijd met pensioen te gaan. Daarentegen is het percentage werknemers dat met pensioen denkt te gaan op 66-jarige leeftijd substantieel hoger voor het I955 cohort (20,0\%) dan het 1954 cohort $(13,4 \%)$.

\section{De inzet van werknemers en hun oordeel over het personeelsbeleid}

Uit dit rapport kan worden geconcludeerd dat de werkinzet van oudere werknemers niet lager hoeft te zijn dan de inzet van jongere werknemers. Oudere werknemers zijn niet minder bevlogen dan jongere medewerkers. Ook maken zij niet minder onbetaalde overuren. Het percentage werknemers dat overuren makt in de leeftijdsgroep van 35 tot en met 44 jaar is wel hoger, maar dit komt doordat medewerkers in deze 
groep vooral vaker betaalde overuren maken dan oudere medewerkers. Daarnaast vinden wij dat het aantal ziektemeldingen bij oudere werknemers een stuk lager ligt (I3,3\%-punt lager) dan bij jongere medewerkers. De oudere werknemers die zich ziek melden zijn echter wel veel langer ziek. Dit laat echter onverlet dat het overgrote deel van de oudere medewerkers geen gezondheidsproblemen ondervindt.

Naast de inzetbaarheid, is op basis van stellingen onderzocht hoe tevreden werknemers zijn over het personeelsbeleid van de organisatie waarin zij werkzaam zijn. Werknemers zijn vrij negatief over het personeelsbeleid, waarbij bepaalde facetten zoals de mogelijkheid om in deeltijd te werken, zorg en ondersteuning en voldoende waardering van leidinggevenden er positief uitschieten. Maar weinig werknemers geven aan dat hun werkgever bereid is om hun taakbelasting aan te passen en vooral oudere werknemers oordelen negatief over de stelling dat hun werkgever meer aandacht is gaan besteden om oudere werknemers langer in dienst te houden. De ontevredenheid van werknemers, het blijven aanbieden van alternatieve uittredemogelijkheden en het feit dat oudere werknemers op bijna alle aspecten van het personeelsbeleid negatiever oordelen duidt er op dat werkgevers nog onvoldoende aandacht besteden aan de inzetbaarheid van hun oudere medewerkers. Ook blijkt hieruit dat de kostenbaten afwegingen van werkgevers op micro niveau in de praktijk zwaarder wegen dan het macro-belang om oudere werknemers te stimuleren om door te werken.

Positief punt is het trainingsbeleid dat door werkgevers wordt gevoerd. De trainingsparticipatie van oudere werknemers is weliswaar lager dan bij jongere medewerkers, maar de trainingsdeelname van oudere medewerkers blijft substantieel. Het gebrek aan motivatie van oudere werknemers om training te volgen blijkt een belangrijke oorzaak voor hun lagere trainingsparticipatie. Jongere werknemers nemen zelf vaker initiatief om een cursus te volgen, terwijl bij ouderen het initiatief vaker van de werkgever komt.

\section{Loonkosten en productiviteit}

Omdat de gemiddelde loonkosten oplopen naarmate mensen ouder zijn, verschuift volgens de werkgevers de verhouding tussen de productiviteit en loonkosten voor opeenvolgende leeftijdsgroepen van een positieve verhouding voor de leeftijdsgroep 35-44 jaar in een negatieve verhouding voor de leeftijdsgroep 55-64 jaar. Dit kan echter het gevolg zijn van impliciete afspraken tussen werkgevers en werknemers, waarbij de inzet en loyaliteit van werknemers gestimuleerd wordt door de lonen aan het begin van de loopbaan lager te laten zijn dan de productiviteit en dit verschil later in de arbeidsloopbaan te compenseren door een loon dat hoger ligt dan de productiviteit. Het verschil in waardering tussen de productiviteit en het loon van 55-64 jarigen is vooral groot bij de politie en het beroeps- en volwassenenonderwijs. Het verschil is het kleinst bij het hoger beroepsonderwijs, de vrijwillige toetreders en de sector overige. Belangrijk daarbij is dat werkgevers echter de kosten van oudere werknemers flink overschatten. 
Oudere werknemers blijken overigens bepaalde productieve vaardigheden te bezitten die bij jongere werknemers nog minder aanwezig zijn. Zo geven de werkgevers aan dat 55-64 jarigen het beter doen dan werknemers in de leeftijd van 35-44 jaar voor wat betreft hun kennisniveau, deskundigheid, zelfstandigheid, nauwkeurigheid, planning van het werk, leidinggeven en het omgaan met verantwoordelijkheid. Ook doen 55-plussers het niet slechter als het gaat om hun probleemoplossend vermogen, communicatieve vaardigheden, klantgerichtheid, samenwerken met collegae en stressbestendigheid. Als het gaat om hun omgang met organisatorische veranderingen, omgang met technologische veranderingen, commerciële vaardigheden en flexibiliteit doen oudere werknemers het volgens de werkgevers echter relatief slechter dan jongere werknemers.

Ondanks het economisch en maatschappelijk belang van een hogere arbeidsmarktparticipatie van ouderen, blijkt slechts I $\%$ van de werkgevers het belangrijk tot zeer belangrijk te vinden voor de personele bezetting dat oudere werknemers langer doorwerken. Dat oudere werknemers relatief duurder zijn zien werkgevers als een belemmering om ouderen langer in dienst te houden. Daarnaast speelt ook het feit dat, volgens de werkgevers, oudere werknemers zelf niet langer willen doorwerken. De grotere ervaring van oudere werknemers wordt wel als voordeel gezien om ze langer in dienst te houden. De bereidheid van werkgevers om ouderen aan te nemen is echter gering.

\section{Personeelsbeleid volgens werkgevers}

Het personeelsbeleid van werkgevers is van belang om handen en voeten te geven aan in CAO's gemaakte afspraken. De meest voorkomende vormen van HRM beleid op het terrein van arbeidsvoorwaarden zijn spaarloonregelingen ( $84 \%$ van de organisaties) en levensloopsparen (66\% van de organisatie). Prestatiebeloning op individueel niveau $(25 \%)$ en gratificaties $(29 \%)$ worden soms toegepast, maar dit geldt veel minder voor andere vormen van prestatiebeloning. Een leeftijdbewust of levensfasebewust personeelsbeleid voeren kan van belang zijn om werknemers duurzaam inzetbaar te houden. Echter, slechts $37 \%$ van de organisaties voert een HR beleid op dit punt.

Van de HR instrumenten op het gebied van loopbaanbegeleiding wordt het POP het vaakst toegepast ( $55 \%$ van de organisaties). POPs worden echter minder vaak gebruikt bij de rijksoverheid, in de bouw en in het wetenschappelijk onderwijs. Coaching en het bevorderen van de zelfstandigheid van werknemers zijn HR instrumenten die ook vaak worden toegepast. Wat betreft het gebruikt van HR instrumenten op het gebied van gezondheid en belastbaarheid blijkt ongeveer driekwart van de organisatie een arbobeleid te hebben. Daarnaast zet de helft van de organisaties HR instrumenten in die gericht zijn op de aanpassing van het werk aan de belastbaarheid van de werknemers. 
De inzetbaarheid en vitaliteit van oudere werknemers verreist een personeelsbeleid dat meer specifiek gericht is op deze groep werknemers. Het blijkt echter dat werkgevers niet zo'n vaart zetten achter het ontwikkelen van een HR beleid dat er op gericht is om oudere werknemers langer te laten doorwerken. De HR instrumenten die het vaakst worden toegepast zijn voornamelijk gericht op het zogenaamde "ontziebeleid": leeftijdvakantiedagen en seniorenverlof. HR instrumenten die gericht zijn op taakaanpassing en opleiding van oudere werknemers komen ook relatief vaak voor: bijvoorbeeld het inzetten van oudere werknemers op taken waar zij goed in zijn en aanpassingen van de werkplek. Instrumenten rond pensioenbeleid worden wisselend toegepast: deeltijdpensioen wordt bijvoorbeeld relatief vaak toegepast terwijl vertrekregelingen door slechts $15 \%$ van de organisaties worden aangeboden. Beloningsprikkels zoals bijvoorbeeld promotie, demotie of teruggang in salaris worden zelden toegepast.

Scholing is een belangrijk instrument in het kader van de inzetbaarheid van werknemers. De meeste organisaties hebben dan ook een specifiek trainingsbudget. Het mediane budget voor het jaar 20 II bedraagt ongeveer $€ 430$ per werknemer. De top 5 van meest populaire cursussen wordt gevormd door cursussen rond: bedrijfshulpverlening, vakspecifieke kennis, coaching, leiding geven en communiceren.

\section{Beoordeling personeelsbeleid door werkgevers en werknemers en invloed op pensioen- verwachtingen en werkinzet}

Werkgevers oordelen doorgaans positiever over het door hen gevoerde personeelsbeleid dan hun werknemers. De grootste verschillen tussen het oordeel van werknemers en werkgevers doen zich voor bij het oordeel over de betrokkenheid van de werkgevers bij het welzijn van werknemers, het personeelsbeleid in het algemeen, de bereidheid om zich in te zetten voor werknemers en het bieden van zorg en ondersteuning indien nodig. Opmerkelijk is dat werknemers daarentegen positiever oordelen dan werkgevers over de waardering die zij krijgen van hun directe leidinggevenden.

De verschillen tussen het oordeel van werkgevers en werknemers over het gevoerde personeelsbeleid zijn vooral groot bij de universitaire medische centra, het wetenschappelijk onderwijs en de politie. In deze sectoren wordt de ontevredenheid van werknemers over het gevoerde personeelsbeleid door hun werkgever fors onderschat. Werkgevers in deze sectoren zijn vooral veel positiever dan hun werknemers over hun betrokkenheid bij het welzijn van de werknemers, de zorg voor hulp en ondersteuning wanneer dat nodig is, de bereidbaarheid om zich in te zetten voor werknemers en hun inzet om werknemers langer aan het werk te houden.

Een belangrijke vraag is vervolgens in hoeverre er een relatie is tussen de hierboven in kaart gebrachte (on)tevredenheid van werknemers over het door hun werkgever gevoerde personeelsbeleid en de verwachte pensioenleeftijd en productiviteit van werknemers. Het blijkt dat het oordeel van werknemers over verschillende aspecten van het door hun werkgever gevoerde personeelsbeleid gerelateerd is aan de verwachte 
pensioenleeftijd. Werknemers denken langer te werken indien zij de mogelijkheid hebben om in deeltijd te werken, zij ervaren dat hun werkgever betrokken is bij hun welzijn en bereid is om hun geestelijke taakbelasting aan te passen als dat noodzakelijk zou zijn.

Opmerkelijk is ook dat werknemers een hogere werkinzet hebben als ze meer waardering van hun leidinggevenden ervaren. Een hoger gevoel van waardering leidt tot minder ziektedagen, een hogere baantevredenheid en meer bevlogenheid op het werk. Ook is er een sterk significant positief verband tussen het loopbaanperspectief en de bereidheid van werkgevers om zich in te zetten voor hun werknemers en de baantevredenheid en bevlogenheid van de medewerkers. De mogelijkheid om in deeltijd te gaan werken draagt eveneens bij aan een hogere baantevredenheid.

Zoals verwacht kan worden op basis van het grote verschil in het beeld dat de werkgever en de werknemers hebben over het personeelsbeleid, is het volgens de werkgevers gevoerde personeelsbeleid nauwelijks van invloed op de pensioenverwachtingen van hun werknemers. Er is alleen een relatie tussen de kans om met deeltijdpensioen te gaan en het hanteren van gesprekscycli en beleid gericht op loopbaanontwikkeling. Ook blijkt de kans dat werknemers met deeltijdpensioen denken te gaan, lager te zijn wanneer er een beleid is dat oudere medewerkers vrijstelt van overwerk.

Ook blijkt het volgens de werkgever gevoerde ouderenbeleid slechts marginaal gerelateerd te zijn aan de pensioenverwachtingen en de werkinzet van werknemers. Alleen beloningsprikkels blijken significant gecorreleerd te zijn met de kans om met deeltijdpensioen te gaan. Deze prikkels vergroten ook de kans op onbetaalde overuren met 6,4\%-punt. Het is aannemelijk dat dergelijke prikkels werknemers stimuleren om meer in hun eigen tijd te werken, om te voorkomen dat zij te maken krijgen met een teruggang in hun salaris. Ook blijkt dat medewerkers van organisaties die veel doen aan taakaanpassing en scholing een $8 \%$-punt hogere kans hebben om te participeren in de levensloopregeling.

\subsection{Aanbevelingen}

I. Veel werknemers overschatten de hoogte van het pensioen dat zij zullen krijgen. Vooral bij jongere werknemers blijkt dat hun pensioenbewustzijn nog onvoldoende is ontwikkeld. Gebrekkige financiële kennis is een belangrijke oorzaak van te optimistische verwachtingen. Deze te rooskleurige verwachtingen leiden er toe dat jongeren minder investeren in hun pensioen, waardoor zij later zelfs als ze langer doorwerken relatief weinig pensioenrechten hebben. Het verdient derhalve aanbeveling om te investeren in het pensioenbewustzijn van jongeren.

2. Een aanzienlijk deel van de werkgevers geeft aan dat gezondheidsrisico's een belemmering vormen om oudere werknemers langer in dienst te houden. Het 
overgrote deel van ouderen ondervindt echter geen gezondheidsproblemen die hen belemmeren om te blijven werken. Het is daarom belangrijk om werkgevers te wijzen op het feit dat oudere werknemers minder vaak ziekteverlof opnemen dan jongeren, waardoor voor een grote groep oudere werknemers de ziekteverzuimkosten lager zijn dan bij jongere werknemers.

3. Werkgevers zijn van oordeel dat de loonkosten van oudere werknemers te hoog zijn ten opzichte van hun productiviteit. Oudere werknemers scoren echter beter dan jongeren op een aantal vaardigheden die van groot belang zijn in het productieproces en de levering van diensten: kennisniveau, deskundigheid, zelfstandigheid, nauwkeurigheid, planning van het werk, leidinggeven en het omgaan met verantwoordelijkheid. Tegen de achtergrond van de krapte die zich over enkele jaren op verschillende segmenten van de arbeidsmarkt zal gaan voordoen, verdient het aanbeveling om de bewustwording van de positieve productieve vaardigheden van oudere werknemers onder werkgevers te vergroten.

4. Ons vignetonderzoek onder werkgevers laat zien dat 55-plussers, ongeacht de werkervaring die ze hebben, niet meer aangenomen worden als ze in de sollicitatieprocedure concurreren met een jongere sollicitant, ook al heeft deze laatste geen enkele werkervaring. Dit betekent dat wanneer oudere werknemers werkloos worden, de kans erg klein is dat zij weer aan het werk komen. Vanuit beleidsperspectief kunnen hier twee lessen getrokken worden. Ten eerste is het in de huidige situatie van belang dat oudere werknemers zo lang mogelijk inzetbaar blijven in hun huidige baan of organisatie. De kansen op een andere baan zijn immers minimaal. Ten tweede zullen de arbeidsmarktkansen van werkzoekende ouderen alleen kunnen verbeteren als er verandering komt in de wijze waarop werkgevers hun afwegingen maken bij het aannemen van ouderen. Enerzijds oordelen zij negatief over de loon-productiviteitsverhouding van oudere werknemers, hetgeen negatief uitpakt voor ouderen in hun aannamebeleid. Anderzijds oordelen zij positief over een aantal productieve eigenschappen van ouderen, zoals bijvoorbeeld kennis, maar dit heeft geen invloed op hun aannamebeleid. Het is dan ook niet duidelijk in welke mate het oordeel van werkgevers over de loon-productiviteitverhouding voortkomt uit de feitelijke verschillen in kosten en productiviteit van ouderen, of gebaseerd is op een verkeerde perceptie daarvan. In dat laatste geval kan actief beleid gericht op het tegengaan van leeftijdsdiscriminatie soelaas bieden.

5. Werkgevers en werknemers verschillen sterk in hun oordeel over het in hun organisatie gevoerde personeelsbeleid. Werkgevers zijn hierover doorgaans een stuk positiever en onderschatten daarmee de ontevredenheid van hun eigen werknemers over gevoerde personeelsbeleid. Deze verschillen leiden er ook toe dat er geen relatie is tussen het volgens de werkgever gevoerde personeelsbeleid en het gedrag van werknemers. Het door de werknemers gepercipieerde personeelsbeleid is echter wel gerelateerd aan hun arbeidsmarktgedrag. Zo is er een significante relatie tussen het oordeel van werknemers over verschillende facetten van het in hun organisatie gevoerde personeelsbeleid en de 
leeftijd waarop zij met pensioen denken te gaan, maar nauwelijks een relatie tussen het volgens de werkgever gevoerde personeelsbeleid en de leeftijd waarop medewerkers met pensioen denken te gaan. Ook is er geen relatie tussen het volgens de werkgever gevoerde personeelsbeleid en de inzet van de werknemers. Werkgevers zullen daarom meer aandacht moeten besteden aan de communicatie over het door hen gevoerde personeelsbeleid naar hun medewerkers en daarbij oog moeten hebben voor de percepties van hun werknemers.

6. Om te bewerkstelligen dat hun medewerkers langer doorwerken kunnen werkgevers inzetten op het vergroten van de mogelijkheden om de laatste jaren van de arbeidsloopbaan in deeltijd te werken. Ook zullen werkgevers hun betrokkenheid bij het welzijn van hun werknemers moeten vergroten, als ook hun bereidbaarheid om de mentale taakbelasting aan te passen als dat noodzakelijk is om iemand langer te kunnen laten doorwerken.

7. Wanneer werknemers een positiever oordeel hebben over het door hun werkgever gevoerde personeelsbeleid, dan zijn ze ook meer tevreden over hun baan, meer bevlogen in hun werk en minder vaak ziek. Organisaties zouden de werkinzet van hun werknemers kunnen vergroten als ze (I) leidinggevenden aansporen om meer waardering te laten blijken voor het functioneren van hun medewerkers, (2) hun medewerkers een goed loopbaanperspectief bieden en (3) laten zien dat ze bereid zijn om zich in te zetten voor hun werknemers. 



\section{Bijlage}

Tabel B.1

Aantal werkgevers die de enquête (geheel of gedeeltelijk) hebben ingevuld, naar sector

\begin{tabular}{|lr|}
\hline Rijk & N \\
\hline Provincies en waterschappen & 22 \\
\hline Gemeenten & 41 \\
\hline Politie & 322 \\
\hline Primair onderwijs & 10 \\
\hline Voortgezet onderwijs & 329 \\
\hline Hoger beroepsonderwijs & 90 \\
\hline Wetenschappelijk onderwijs, onderzoek en wetenschapsbeleid & 21 \\
\hline Beroeps- en volwasseneneducatie & 21 \\
\hline Universitaire medische centra & 28 \\
\hline Water, energie en nutsbedrijven & 4 \\
\hline Vrijwillige toetreders & 32 \\
\hline Overige & 140 \\
\hline Bouw & 23 \\
\hline Woningcorporaties & 159 \\
\hline Schoonmaak- en glazenwassersbedrijven & 51 \\
\hline Totaal & 58 \\
\hline
\end{tabular}




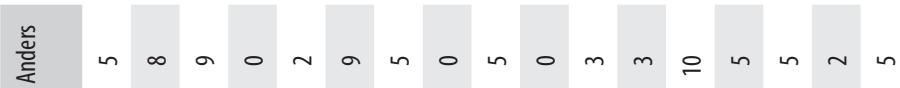
岕 旁

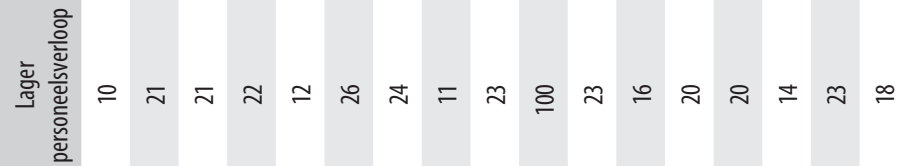
壱 离 离

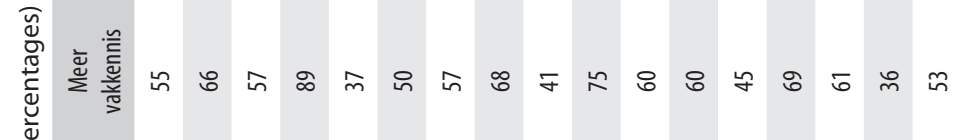
竞离

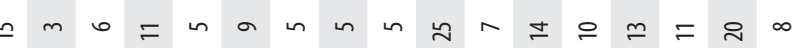
章

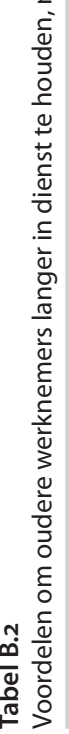
- 


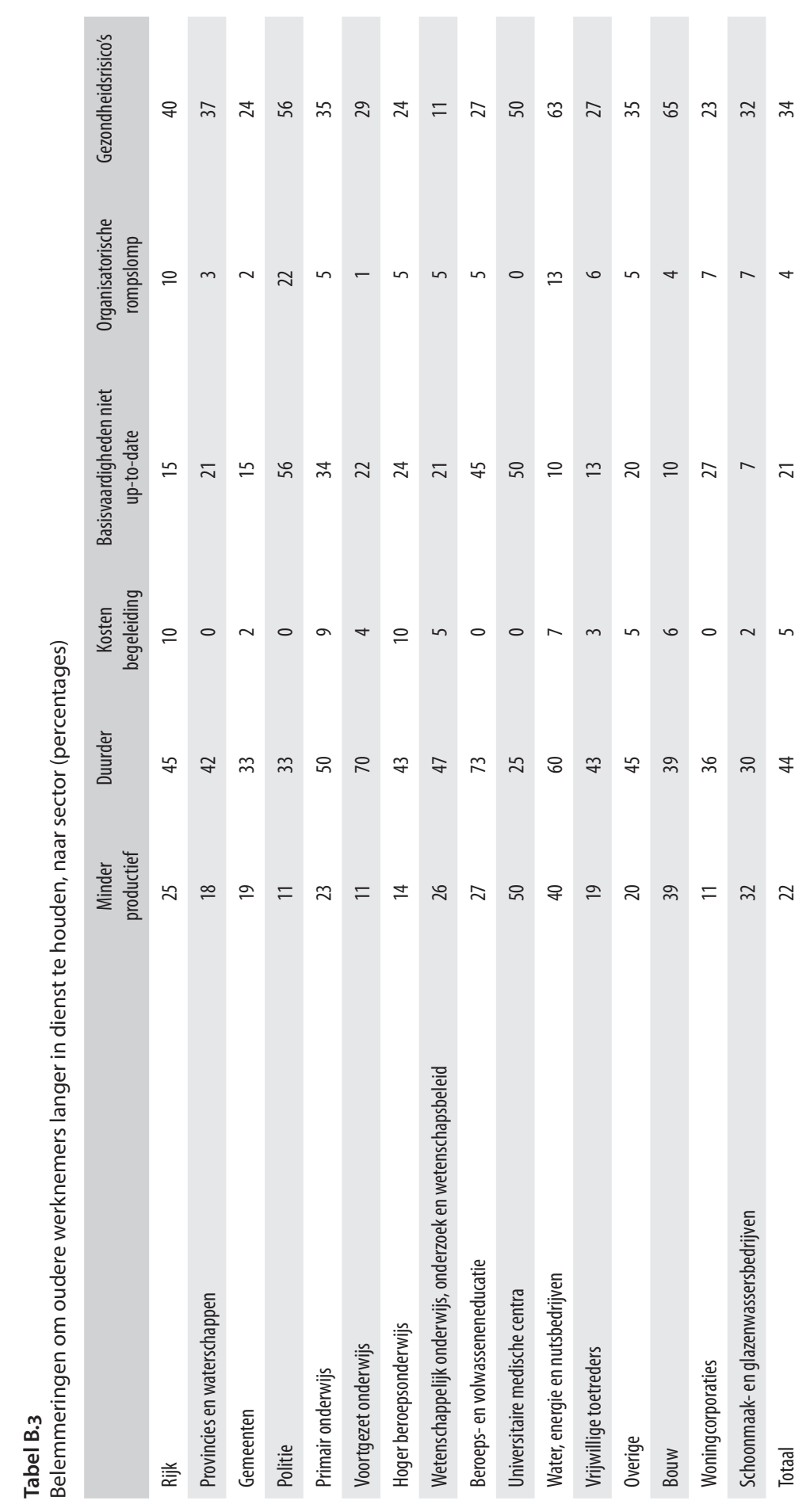




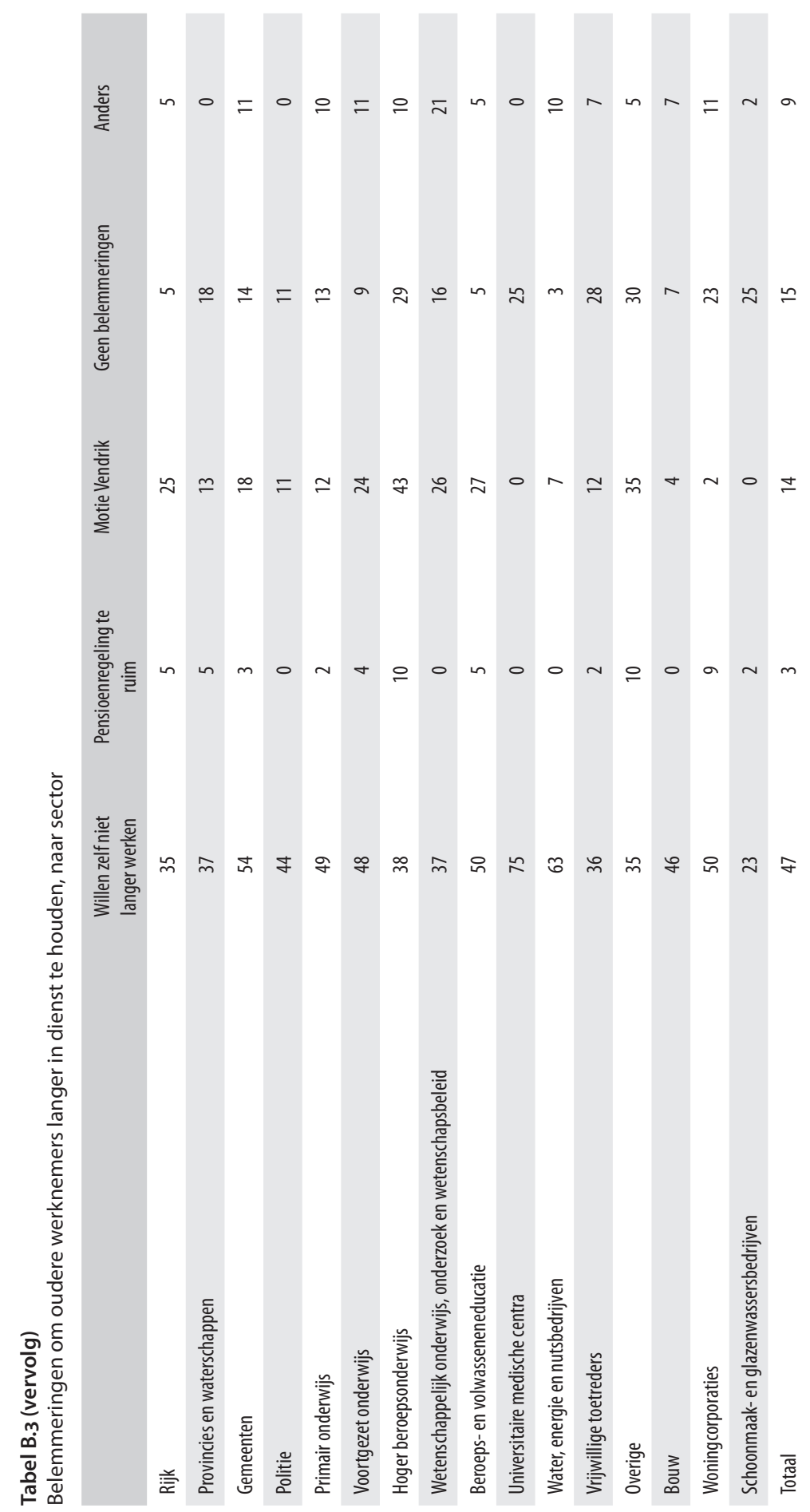




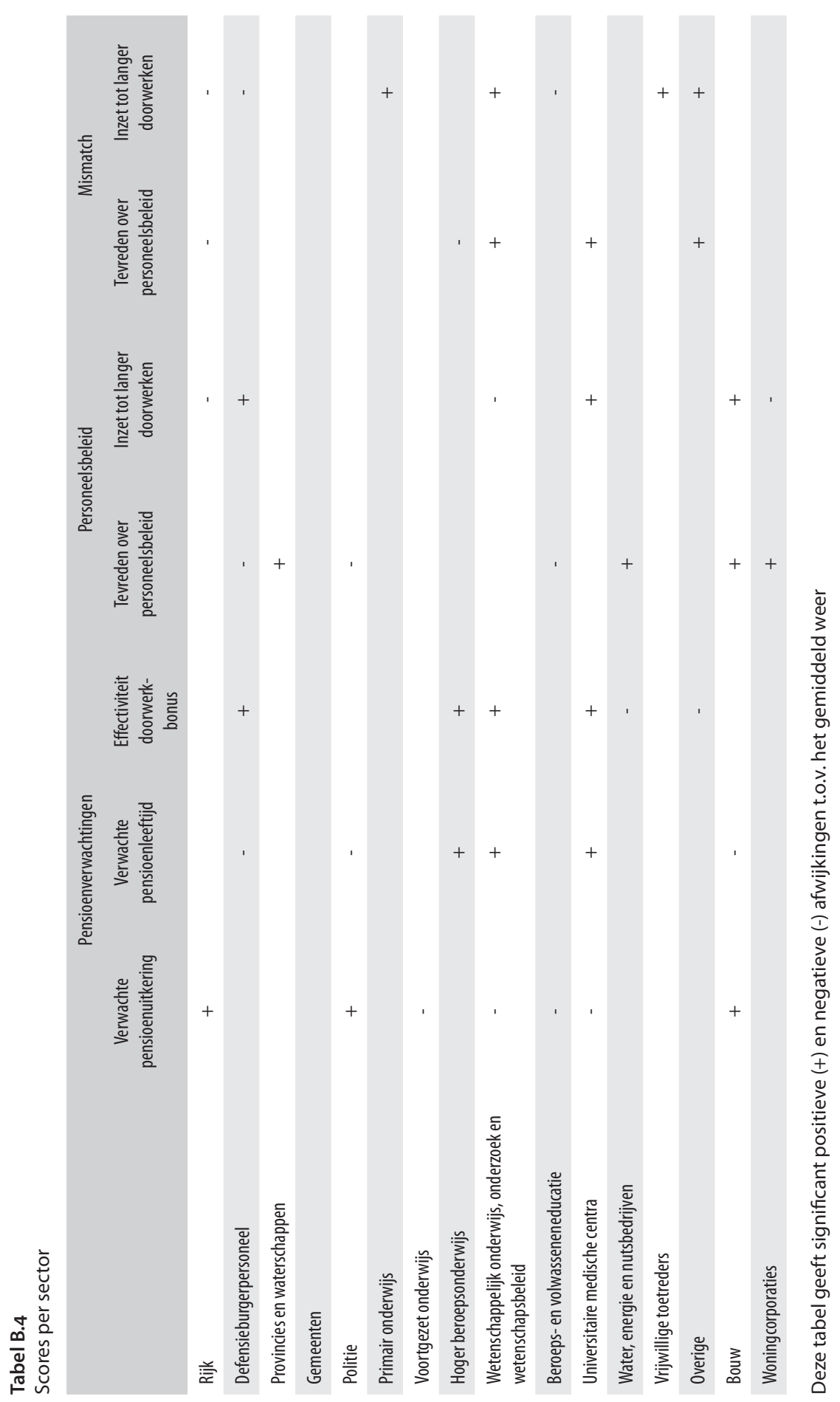




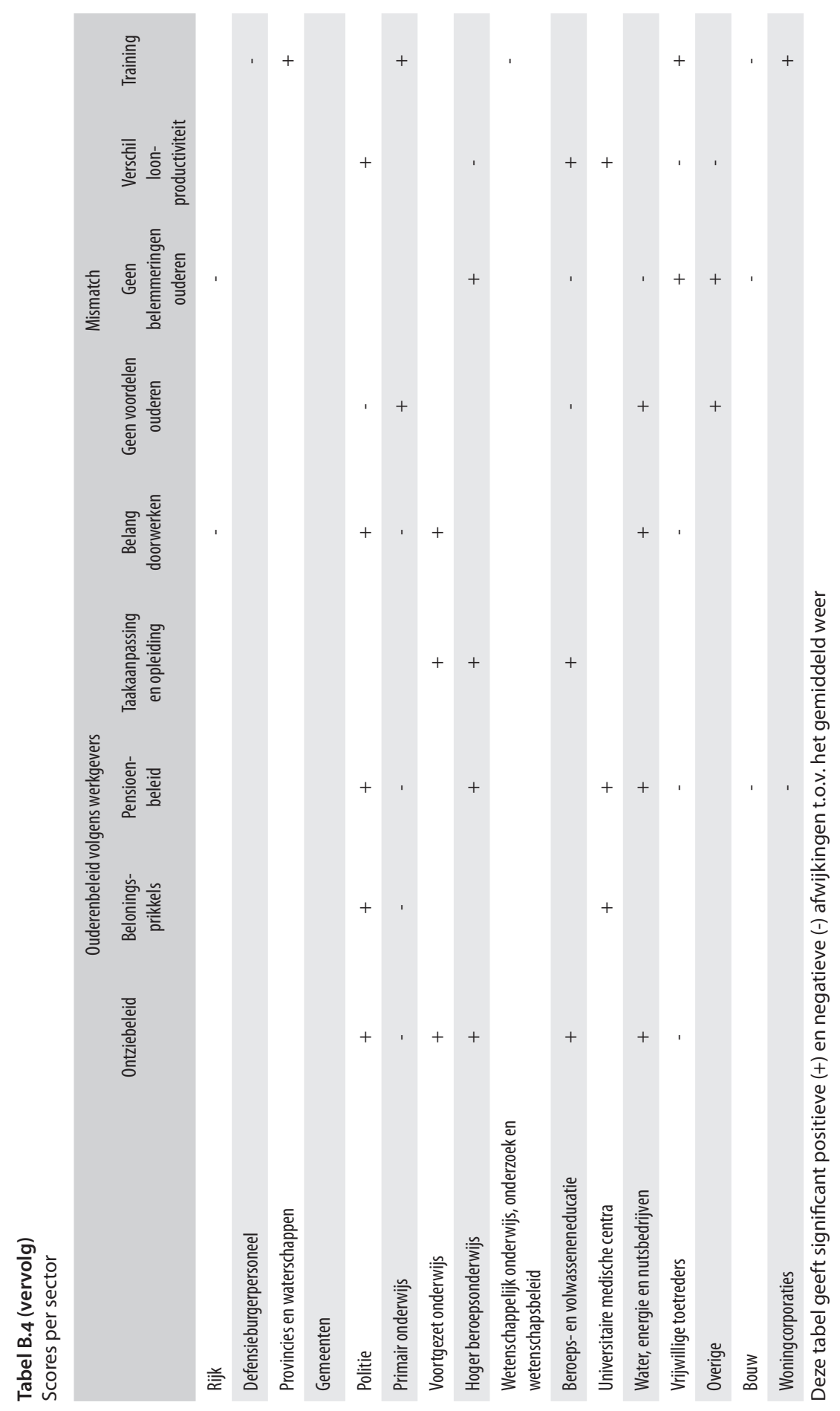

